起を期待する次第である。

此の記念論文を発刊するに当り最初は単独出版も計画した。然し，それでは折角の文献方資料と して後世に残らないし， 又先生の烈々たる研究意筱が弘く耳鼻咽喉科専門家に徹底しないうらみが ある。それで耳鼻咽喉科臨床誌主幹 後藤光治教授に相談したところ同誌に掲載すべしとの快諾を 得たばかりでなく格別の援助をも約束された。同誌編集の方々も亦おしみなき便宜を与えられた。 記して媣く感謝の意を表する次第である。

昭和 35 年 1 月 1 日

森本 正紀記

\title{
I 耳性化膿性脑軟膜炎に関する研究
}

\section{は し・がき}

反省こそは進歩のもとである，温故なくして知新はあり得ない．私は敢えて過去の業績を誇示し ようとするものではないが，又卑下するものでもない．科学者として冷静に過去を回顧し批判し反 省し，それを基本として将来への道を拓きたい，否拓いてもらいたい，との一念から此の機会に従 来の研究をまとめたのである.

I 耳性化膿性脳軟膜炎に関する研究

II 耳鼻咽喉科に関する航空医学の研究

耳疾患は恩師和辻先生からの伝統でもあり，私自身も最も興味をもつて研究したものの一つであ る. そしてその脳内合併症, 就中化膿性脳軟膜炎は私が精魂を傾注した研究課題の一つなのである.

私が脳内合併症の研究に特に必要性と興味を持つに至つたのは, 外科の助手時代に恩師猪子先生 が当時の日本外科学会に脳脊髄外科の専攻者のいない事を嘆かれ，その方面の研究を愍汿せられた 事に始まる，もし私がずつと外科に留まつていたら，刨論それを専攻する考えであつたのたが，そ の後, 或る事情のために，耳鼻科に転じたため，その希望は実現するに至らなかつた，然しその後 も, その考えは常に私の脳裏から離れなかつたのである。ところが, 私が耳鼻科に転じて 4 年目 に，奇しくも私の長男がインフルエンザ耳炎に脳軟膜炎を併発して死亡すると云う事件が起きた。 そしてそれは私にとつて此の上もない大きな衝撃となつた。 その病気は, 当時の日本の学問では, ぞうにも救いようのない合併症なのであつた，当時, 耳科学では日本の第一人者と云われた和辻先 生ではあつたが，ぞうにもならなかつた，天命だ，あきらめようと自分に云い聴かせた私ではあつ たが，自分の最愛の子供の事である，そう簡単にはいかない。自分と同じ悲しみを味わつた同胞の 少くない事を思うと，居ても立つても居られない. 自分の不甲斐なさは勿論の事, 当時の学問をさ え呪う気持になるのであつた. 何とかならぬものか, 否, 何とかせねばならぬ, 「ょしおれは一生 をかけて此の研究をして見よう」, その夢を抱いて私はドイッ留学の旅に立つたのである. 1923年(大 正12年 6 月）の事である.ベルリン滞在の 2 年間, 私はドイツ脳外科の第一人者と云われた Dr.

Krause の手術見学を続けた。そこで見学し得たものは脳並に尙髄の腫瘍のみであつたが，脳や脊 髄を取扱う一般の外科的知識を得て, 爾後の研究に役立つ事が非常に多かつた。

1925年（大正14年）帰朝後, 私は新潟医科大学に教授として赴任し, いよいよ念願の研究に専念 し得たのである．而かも良き協同研究者に恵まれ，且つ田舎の事とて症例の比較的多かつた事は私 にとつて何よりの幸であつた。 
茲に私が此の研究を取䌂めようと考えついたのには二つの理由がある，一つは長年に亘つて努力 した仕事であるし，数多い協同研究者の協力の跡を偲ぶと云う懐古的な意味もあるが，他の一つは 多数の優秀な化学製剤や，抗生物質が発見せられた今日に於ても，本疾患はなお依然として難治の 疾患である事, 従つてその治療の主体は依然として外科的療法におかれねばならぬと確信するから である。

茲に私が取緾めた研究は，主として新潟大学に於て私の協同研究者によつて行われたものである が，その一人である岩手医大，金野㟉教授門下の人々，又私と志を同じくし私のなし得なかつた分野 を受持つてくれた大阪女子医専（現在の関西医科大学）高原高三教授並びにその門下の人々の業績, 私の最も畏敬する岡山大学田中文男教授とその門下の人々の業績, 猶更に之等以外で私共のアイデ アに同調実施せられた方々の研究や症例である。“従つて大正の末年から昭和30年頃までの日本に於 ける本症治療研究の歴史と云う事も出来るかとも思う。

終りに昭和 6 年 8 月，北越医学会雑誌に掲載した私の論文「最近我が教室における化膿性脳軟膜 炎の治療法」の始めの一節を茲に摘録する。それは当時の私の心境をよく云い現わしているからで ある。

「同じく化膿性脳軟膜炎と云うも結核性のものは暫らくおき，流行性脳脊髄膜炎にあつては，免 疫血清療法に多大の期待がかけられるに拘らず, 他の化膿菌感染による脳軟膜炎, 特に耳性又は鼻 性のものでは, 近年まで実に惨娮たる予後を見せており, 化膿性脳軟膜炎の診断がつけられる事 は，則，死の宣告を受けると同様だつたのである.

医学特に外科方面に於ける近年の進歩は, 従来不治と云われた難症に向つて, 刻々征服の歩を進 めてはいるが，なお未だ吾人の理想を距ること甚だ遠い．吾人の精魂は，か〉る難治の疾患に向つ て注ぎ込まれねばならぬ。

吾等は斯かる症例に遭遇する毎に不眠不休の努力と，あらん限りの脳漿を絞つて極めて慎重では あるが， 又，極めて大胆に種々の観血的操作を次から次へと行つておる．然し，その成績は，ま だ，吾々の理想とは余りにもがけ離れている，今日此の方法をもつてすれば，と思つたものも，次 の不幸な症例に遭遇しては，裹れはかなき一場の夢と化した。そこで，更に次の方法を考案する。

中略．但し吾々は之等に就いて泣き言を並べるのでもなければ，又，決して匙を投げるものでも ない. 吾々の精魂の続く限り研究を重ねて, 次に来る者への基礎となり, そして従来の治癒率に一 歩の前進をでももたらし得れば満足である，幸いにも吾々の取扱う之等症例の多くは，急性のもの であるから，或る一定の期間に適当な治療を加えるなら，之を治癒に導き得る見込があるのでそ の点慢性疾患の比ではない。これ，メスを持つ者の最も苦心するところでもあるが，又，苦心の 仕甲斐のあるところでもある。

猶，くれぐれも吾々の努力せねばならぬ事，忘れてはならぬ事は，本症に対しては最後の死線期 までも絶望し力を落してはならぬ事である.」

（鳥居 記）

目

1. 本症の治瘜率とその変遷 新治療法の最初の症例 (1)-(4) (鳥 居) 本症の統計的観察

(三林茂)

2. 本症の原病巣としての内耳炎站に内耳周囲炎 本症の診断に関するもの
(鳥 居)
次

早期診断について

類症鑑別について

（樑瀬 他）

（前 田）

3. 本症に関する基礎的立に実験的研究

解剖学的研究

錐体の組織解剖学的研究 （下田, 森田)

内リンパ管と囊 
外リンパ管

4. 髓液に関するもの

リコール第刺の意義

持続排泄に関するもの

5. 綜 説

6. 本症の薬物療法

全身的使用法に関するもの
(広 谷)

（金野他）

(前田, 渡辺)

(深 瀬)

（鳥 居）

7. 綜 説 $^{\text {斯注入 }}$

（前田，深瀬，菊池，鹿野，矢部）

補助操作々補助薬

(前田, 深瀬, 菊池)

脊椎管内注入療法

（金野，深瀬，菊池，三林，鹿野）

(林)

（鳥 居）

\section{おことわり}

主だつた研究の抄録を主体とし，鳥居教授の綜説を所々に挿んだ。為に，重復した記載がある訳だ。鳥 居教授の綜説を先に読みその中に出て来る個々の研究を後に読むようにすれば，詳細が判明して可いと 思う.

\section{耳性化膿性脳軟膜炎の治癒率に就いて}

1926年（大正末年）頃までの日本の文献では， 1916 年に加藤 (亨) 教授の腰穿反覆と連菌血清の腰槽注入 による 1 治験例，1926年に中村登教授の頻回腰第によ る 1 治験例の報告を見るに過ぎない。

然し，その後新大教室に於て，

1927 年(昭 2 年)鳥居の内耳摘出による 2 治験例 $\cdots(1)$ 1928年(昭 3 年),鳥居の内耳道開放による 1 治験例(2) 1930年(昭 5 年)鳥居の脳橋槽開放による治験例 $\cdots(3)$ 1931年(昭 6 年)鳥居の腰椎管開放による治験例 $\cdots(4)$ 等の治験例が相次いで報告せられ，本症の予後にも明 るい希望がもたれるようになつたのである。 それら症 例の記録をつぶさに読んで行くと，うまくいかなかつ た治療法に鋭い反省と工夫が行われて，よりよき次の 方法へと進んで行つた足跡がよく判るので，之等の数 例を順を追つて記述して見ようと思う。

(1)の症例

\section{迷路全剔出によつて治癒した耳性化膿性脳膜炎の \\ 2 例}

鳥居恵二，耳鼻臨床，21. 1. (昭和2.9)

（その 1) 30才 우，大正 15 年 9 月 14 日入院

臨床診断 : 左側真珠症と顔面神経麻痺

病歴：3才頃より耳漏あり, 消長しつつ今日に至 る. 難聴, 耳鳴, 偏側の頭重感がある, 但し眩軋を覚 えた事なし．約 5 年来顔貌の不整を来たした。

所見: 患側鼓膜は全欠損, 固有鼓室及び上简の一部 に互り少許の肉芽及び分泌物がありその表面は滑沢， 鼓室上筒, アントルム, 乳様峰巣の大部分は外耳道に 向つて開く一大空洞をなし, 恰も巧妙なる耳内手術創 を見るようで，その内面は総て蒼白且つ滑沢である。

手術 (9月22日), 上記の固有鼓室及び蜂巣を清掃 する目的で，まずその中の虫様形の突起を除去せんと 鉗子を用いて引張つた。僅に抵抗を感じただけで比較
的容易に引き出し得た。 引き出して，ハツと思つたの だが，之は凡そ $2.5 \mathrm{~cm}$ 長の蒼白で光沢のある索状物で あり，一見して神経線維である事が判つた。測らざり き，之は顔神の断端だつたのである，果せるかな，之 と同時に，多量の「リコール」が流出して来て拔去す ベくもない，急いで「タンポン」を挿入して手術を中 止した.

因みに云う, 本患者の顔神麻痺は 5 年来のもので, 見たところは末悄性の不全麻痺程度のものであつた。 内科での退化反応検查の結果も, 同様の診断であつた ので, その神経の断端が此処に出ていようとはつゆ考 えなかつたのである.

経過, 同夜より翌日に互り嘔吐 9 回, 発熱 $38.7^{\circ} \mathrm{C}$, 頭頂部に激痛を訴え, 次の日には両側特に患側の腓腸 筋に圧痛が見られ，術後第 3 日の腰穿で圧 240 ,ノンネ， パンジー共に強陽性, 蛋白総量 $0.033 \%$ 上, 多核白 血球 1,150 , 淋巴球 213 , 培養では無菌.

第 2 回手術: 耳後より入り, 迷路の全摘を行い, 後 頭蓋腔の脳硬膜を露出し, 之に十字切開を加えた. 術 後頭痛去り，3 日後の腰穿では, グロブリン反応及び 蛋白量は変らないが, 多核白血球 812, リンパ 球 366 となつた。 2 日後第 3 回の腰穿を試みたが, 僅かに 2,3 滴の液が出たのみ. 眼底検查で患側乳頭に僅かな充血 を見た. 4 日後第 4 回の腰穿では圧 80 , 透明, グロブ リン反応弱陽性, 多核白血球 127 , リンパ球 45 , となつ た。その後熱も漸次下り，10日後には全く無熱，一般 状態も良好となり，入院62日で全治退院した。

迷路摘出後に患側に向う特発眼振が出たが術後 4 日 で消失した。体動時の眩量感は約 1 ケ月続いたが,その 後は自由に歩行し得た. 内耳道からの「リコール」の 流出は約 1 ケ月で自然に停止した. 迷路摘出と同時に 「ウロトロピン」の静注を始め,23日間, 79回に及んだ. 以上, 本症例は真珠症で鼓室, 鼓室上窩, 「アント 
ルム」, 乳様蜂巣なぞが広沉に破壊せられ，而も幸いに も自然治瘑の状態になつていた. 然し顔神管が同時に 侵され，神経線維が断裂し，その断端が創面に露出 し，それを中心とし污臓な肉芽と分泌物があつたので ある、神ならで知る由もなく，それを引き出したので ある. 結果的に見れば之は術者の大失敗で，そのため に化膿性脳軟膜炎を起したのである。他に方法を知ら なかつたので, 最も近接せる迷路の摘出を行い，内耳 道からリコールの流出を企図した訳である，幸いにそ の企てが当つて治瘜に導びき得たのであるが，怪我の 功名と見るべきである. 但し，之が好い機会となっ て，術者が内耳摘出を積極的に行うよう勇気ずけられ た事を此処に告白し, 当患者に限りない感謝の意を表 する次第である。

（その 2）12才，，入院，大正15年12月16日

診断 : 右亜急性乳乫炎, 脳硬膜外膿瘍, 化膿性脳軟 膜炎

病歴：2 ケ月前水泳後に耳痛, 次で耳漏, 10日後に 耳後の腫脹を来たし切開を受けた。然し耳漏は益々増 し, 発病後56日目に患側の頭痛, 悪心, 嘔吐等が現れ た.

所見 : 乳突に強度の圧痛がある. 外耳道の後上部は 著しく下垂し, 鼓膜下半部にある穿孔からは強い悪臭 ある液を多量に出している. 鼓膜, 外耳道は，一般に 発赤著明, 聴力は気導, 骨導共に著しく短縮, 特発眼 振なし, 項强直弱陽性, ケルニヒ症状あり, 足反跳左 に著明，腱反射は総て著しく六進.

手術 (10月16日) 乳突の表面は粗造, 内部は蜂巣も 「アントルム」も総て肉芽と粘稠な液を以て充たされ ている. 頓骨弓の上方に約 $50 \mathrm{cc}$ をれる脳硬膜外膿瘍 を発見した。横洞は露出せず. 腰穿所見, グロブリン 反応陽性, 細胞数 3 , 培養で連鎖状球菌を見た。 その後 4 日を経ても分泌物がなお多量で一般状態も悪い。

第 2 回手術. 根治手術に改变. 砧骨なく, 棺骨も僅 にその頭部を残すのみ. 半規管周囲の骨質が甚だ脆弱 で，半規管と錐体後面との間に小瘦孔がある. 然し此 の部は甚だ狭く，半規管を除去しない限り之を追求し 得ないので中止.

此の際横半規管には肉眼的に異常を認めないが，ガ 一ゼで圧迫すると眩暈を訴え, 患側に向う特発眼振が 出る. その後, 体動時に眩暈感がある. 悪心, 嘔吐は 去る. 3 日後, 両側特に患側に強い乳頭槐血を見, そ の成立が古いと云われた。次の日に嘔吐 3 回, 眩厙, 頭痛を訴え，患側に向う特発眼振はなお存する．足反
跳は両側特に健側に著明. 第 2 回腰穿, 圧 180 ,グロブ リン反応陽性, 中性多核白血球8, リンパ球 100 , 一般状 態不良, ケルニヒ症候現われる。

第 3 回手術. 迷路全摘出. 前述せる半規管内方の瘦 孔を追求すると，内耳道の下を通つて錐体尖端に達 し，其処に腐骨塊を入れていた．途中の骨質は総て脆 く，肉芽を混じている. 術後 1 ～2 日より一般状態が 漸次良好となり食照も出た. その後, 病的反射も次々

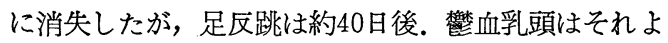
り更に 24 日遅れて漸く消失した。

迷路破壊時並にその後に於ける特発眼振に就て。術 時に於ては，初め術側に向う緩徐な水平眼振があり， 術を進めるに従い頻且つ活潑となり，手術直後には同 上方向の眼球転位と少数の眼振を見た。翌日には健側 に向う頻且つ活潑な水平, 趈転眼振を見たが, のち比 較的速かにその度を減じ，5 日後には極めて微弱とな り，6日目には全く消失した。

歩行時の眩量感は，第 1 例と同じく，術後約 1 力月 間続いた。

このようにして一般状態も漸次恢復し，約 3 力月後 に外来に転じた。

（2）の症例 28 才，令，農，昭和 2 年 4 月19日入院 診断：右側严急性乳様突起炎, 化膿性脳軟膜炎, 小 脳膿瘍

病歴：約 20 年前より耳漏あり，一進一退し今日に至 る. 右の耳はこ> $2 \sim 3$ 年は分泌極めて僅か. 4 ケ月 前耳内ポリープの摘出を受けた。

数日来分泌が激増し，局所に熱感ありその側の偏頭 痛と眩暈を感じ, 耳鳴, 難聴の度もまた増加し, 時々 悪感あり。但し嘔気，嘔吐等なし。

所見 : 右の項部一般に腫脹し, 胸鎖乳突筋に添うて 圧痛がある。外耳道は後上壁が下垂し，その入口より $1 \mathrm{~cm}$ 所で全く閉鎖し，それより深部を窅うことが出 来ない. 分泌は多量だが悪臭はない. 聴力は患側の気 導全く消失し，骨導10秒。ロンベルグ症状あり，健側 に倒れる。特発眼振，健側に向い，廻転眼振 ( 3 迴転) 患側に於て $2 / 5$, 健側に於て $28 / 27$, 特発偏示なし. 腱 反射正常.

即ち患側は涺漫性化膿性内耳炎の像を呈し, 体温は 最高 $37.6^{\circ} \mathrm{C}$

根治手術：4月20日，骨皮質緻密，顔神隆起の部分 粗造, 横半規管の部に瘻孔あり；アントルム入口部よ り鼓室にわたつて粘膜肥厚し, 真珠腫を入れる. 桘骨 は壊死に樎り，砧骨は既に存せず，外耳道の後骨壁破 
壊消失し，その皮膚に欠損あり，肉芽とポリープを以 て充さる．S状洞及び脳硬膜に欠損を認めず．起炎菌 培養で連鎖状球菌を証明.

経過 : 術後 9 日間は熱に多少の弛張あるも最高 37.7 ${ }^{\circ} \mathrm{C}$ 第 9 日には平熱に復し，一般状態が良かつたが，そ の翌日より再び発熱し，漸次上昇して $38.6^{\circ} \mathrm{C} に$ 達し， 後頭部に知覚過敏あり, 項強直, ケルニヒ症状疑わ し.よつて腰椎穿刺を行う. 圧 170 , 肉眼で雲絮状润濁 を見る.グロブリン反応卅，糖 $0.1 \sim 0.05 \%$ ，細胞数 2,134 , 培養にて連鎖状球菌を証明. 跟底両側乳頭充血

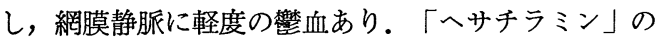
静脈内注射を始め，その翌日迷路手術を行う。

所見：半規管何れも破壊し，周囲の骨壁は，全く肉 芽を以て充たされ，後頭蓋腔の脳硬膜は充血肥厚して 搏動なく，小脳表面に痹着し，此処に切割を加えても 「リコール」は流出しない。

経過：翌日頭痛軽快, 悪心なし, 特発狠振の患側に 向う軽度のものがある. 体温 $38.4^{\circ} \mathrm{C}$ 迷路手術後第 3 日 消息子を顔面神経の経過に添うて内耳道に挿入する と，「リコール」が盛んに流出した。体温 $38.9^{\circ} \mathrm{C}$ 第 5 日, 頭痛減少, 此の日健側の難聴を訴う. 体温 $38.2^{\circ} \mathrm{C}$ 第13日，頭痛消失，項強直 $( \pm)$, ケル二と症状減少, 腰椎穿刺（第 6 回）殆んど透明となる. 体温 $37.7^{\circ} \mathrm{C}$, 以後, 全く平熱に復す. 第17日, 項強直なく, ケル 七症候僅に存し，右の術創分泌少訐，自敩的に棂快。 食慾盛ん。2 週日来訴えられていた他側の難聴も大い に恢復し，ほほ術前のものに近ずいた。

かくの如く根治手術に遅れる事10日で化膿性脳軟獏 炎を惹起し，その診断の確定した翌日に迷路全摘を行 い，内耳道より「リコール」の排泄を計り，加うるに 毎日又は隔日に腰椎穿刺を行い，且つ「へサチラミン」 の注射をも持続したところ，迷路手術後10日にして全 く平熱に復し, 諸症状緩解し, 外観上全く恢復の状を 呈した。而してその後 2 週日に亘り極めて平穏に経過 し，患者は床上に坐し，嬉々として日々を送つた。

因に，本患者はその後，2 個併立せる我卵大の小脳 腫皛のため死亡した。特志によつて局所を剖見した が，脳膜炎は肉眼上その痕跡をも認める事が出来なか つた.

(3) の症例

内耳摘出, 内耳道附近に於て脳橋慒を開放し治癒 した耳性化膿性脳軟膜炎の症例

鳥居恵二，耳鼻臨床， $24 ， 2$ ，(昭和 5 年）

13 才, $\delta$, 昭和 4 年 9 月 14 日入院
病歴: 約 2 力月前, 海水浴中に右耳克強く打たれ た。 その夜軽度の耳痛があり某医より鼓膜穿孔と出血 があると云われた。そ後 2 週間は苦痛がなく，次で 軽度の耳痛を覚えたので治療を受けていた．25日前に 発熱 $38^{\circ} \mathrm{C}$, 激しい耳痛あり，翌朝乳様突起の単削開術 を受け，順調に経過した。約 2 週間後に頭痛，呕吐 2 回あつたが，その後異常なし. 約 2 週間前より軽度の 頭痛, 食慾不振, 呕吐 1 回あり, 10 日前の朝, 呕吐 2 回，頭部特に後頭部に激痛あり，食照不振，不眠を来 たし，4 日間続く。その間に呕吐 3 回.

入院時の主訴：激しい頭痛と呕吐

所見 : 顔貌無慾状, 意識鮮明, 瞳孔は患側がや > 小，光線反射両側羊鈍，患側に向う水平特発眼 振 あ り，両側の眼球と下顎窩に圧痛がある．患側耳の後方 立に側頭部に圧痛及び咑打過敏あり．外耳道上壁は可 成り下垂している。鼓膜は軽く充血して凹凸あり, 聴 力, 高度の下音界上昇あり, 項強直軽度, 腹壁反射, 右側や > 六進, 両側の提辠筋反射, 滕蓋腱反射等消失 し，ケルニヒ症状陽性，脈搏46.「リーコル」所見，圧 180, 軽く溷濁.「グロブリン」反応卅, 蛋白量 0.055 , 糖量 0.047 細胞数 166 (中性多核白血球 $29 \%$ )，細菌な ᄂ.

血液所見 : 白血球 9680 (中性多核白血球增加, リン パ球滅少，好エオデン細胞 0$)$.

手術所見 : 外耳道後壁には多量の肉芽と少量の粘液 を認める．S状洞壁，アントルム上壁及び乳様突起尖 端部には蜂巣が多く肉芽を以て充たされている，之等 を削除して精細に調べたが，骨皮質に欠損はない.ア ントルムも肉芽で充たされ, 顔神隆起と横半規管の表 面は粗造，鼓室も肉芽をもつて充たされ，桘骨と砧骨 は遊離して肉芽中に埋没し，鐙骨も殆んぞ抵抗なく除 去し得た．鼓室天蓋にも骨の欠損を認めないそそこで トラウトマン三角及び半規管を破瀤しつ>内耳道附近 に至る。その部の骨質は脆弱で海綿犬を呈し，肉芽を 容れている. 削除を完全に七たのち内耳道の直後方で 脸硬膜に上下の切開を加えると，軽度に濁つた多量の リコールが貲出した。

経過：翌日に呕吐が 1 回あつたが，病的反射は消失 し，脳硬膜切開創より消息子を入れると透明な「リコ 一ル」が少量出た。その後一般状態は良くなつたが， 症状に応じて腰穿と「ウロトロピン」の静注を行つ た。18日間に亘つてリコールの流出を見た。特発眼振 も第 3 日より軽減し，約 3 週間後には極めて軽度にな つた。項強直は約 1 週間後にケルニヒ症候は 2 週間 
後に消失，脈搏数も第 5 日には漸次に熱曲 線に近ず き，9日後には全く正常化した。

眼底所見: 第 3 日目から約 2 週間後までやや強く発 赤し，境界不鮮明な乳頭（殊に患側に強し）及び小出 血斑及び静脈の怒張を認めたが，そののち急速に改善 され，第 3 週間後には極めて軽度となつた。

「リコール」の所見

第 3 日，外観透明，圧160,グロブリン反応卅，蛋白 量術前に同じ，細胞数35（リンパ球対中性多核白血球 の比は $1: 2$ )

2 週間後, 圧140,グロブリン反応陽性, 蛋白涉びに 糖量は正常, 細胞数 4 (リンパ球のみ).

\section{血液所見}

第 3 日目，白血球 8900 (分葉核 $43 \%$ ，リンパ球 50.2 \%，好エオデン細胞 1.5\%)

2 週間後，白血球 4,720 (分葉核 $52 \% ，$ リンパ球 31.2 \%，好エオデン細胞 $4 \%$ )

総括 : 本例はその経過や手術所見から見て, 内耳炎 に始まり，内耳道を経て脳軟膜炎を起したものと考え られる. 即ち中耳から内耳一の伝播経路は迷路の周囲 或は卵円空であり，その部の化膘性炎を起す事なく， 速く内耳道を経て脳膜に波及したものであろう。

本例に於て注目すべきは, 脳膜炎症状の発生後, 比 輘的早期（恐らく第 3 日目に）内耳手術及び脳橋槽の 開放を行つた事が治瘜を可能にし, 又, 内耳道を開放 しないで，その直後方で䋞膜を切開したために，顔神 麻痺を起さなかつたし，18日間に互る「リコール」の 流出を続け得た事である。從来の内耳道を開放する術 式では，その附近の痹着が早いためか，長くとも 1 週 間位の排泄を続け得るに過ぎない事実と較べて非常に 大きな利点があると考える.

\section{(4) の症例}

\section{最近我が教室における化震性脳膜炎の治療法（内 耳摘出一脳橋槽開放一腰椎管開放)}

鳥居恵二, 北越医会誌46. 8 (昭6. 8)

（その1）28才， 䭪髮業

主訴 : 眩量 (身体の上下動摇感) のため労作不能， 時々警う頭痛, 右の難聴及び耳漏

病歴 : 約 20 年前より右の耳漏あり，一進一退し感冒 後は常にその量を増し, 眩量, 頭痛, 悪心, 時に呕吐 がある。漸次難聴の度が増して来た。 6 力月前より， 月 1 回位, 右の耳痛, 発熱, 呕吐, 眩暈なぞを来た し，歩行中俄かに倒れる事があり，又，労働時には身 体の上下に動摇する感じがあつて仕事が出来なくなつ
た。

局所々見: 右鼓膜は殆んぞ全く欠如し，ただ短突起 のみ隆起として認められる. 牚孔縁の中央部に肉芽の 発生があり，その上に出血站に凝血痂が附着してい る.

聴力は気導の総てを欠如し，骨導 5 秒，リンネ陰 性, ウエーバー健側に偏，ロンベルグ症候は著しくな いが，片脚直立では各々その側に仆れる。

自発眼振は患側に向うが軽度, 趈転後眼振検查では 患側耳に於て著しい機能充進が見られる。

以上の所見より慢性上鼓室化膿兼高度の漿液性内耳 炎と診断。

血液に立に咀茺液のワ氏反応陰性.

レントゲン写真では高度の蜂巣発育障碍が見られ る。

経過：まず対症療法として安静, 患側内耳の「ラジ ウム」照射 $1290 \mathrm{mg} / \mathrm{st}$ を行い，1 カ月間の経過を見た が，少しも症状が緩解しない，それで中耳根治手術兼 内耳の部分的切除を行う。

手術所見 : 乳様突起の骨皮質が極めて厚くて硬く， 蜂巣らしいものは一つもなく, アントルムを発見し得 ない.よつて先ず外耳道軟部を切除し, 外耳道より鼓 室立びにアチツクの局所関係を明らかにして逆にアン トルムを索めた。開き得たアントルムは小さな腔で鼓 室上窩にかけて肉芽を充たしている，砧骨は長脚を失 つて肉芽内に埋没し，棺骨も亦その把柄部を失い僅か に頭頸部を存するのみ. 卵円空と思われるところから 少許の膘汁の流出を見た. 此の附近をガーゼを以て拭 えば矓莗を訴え，他覚的には，右に向う第 3 度の自発 眼振を認めた。よつて根治手術後, 前庭立びに蝸牛款 部の摘出を行つた。

因に，本患者の如き内耳機能障碍の程度では, 内耳 摘出の正常の適示はない，機能が殆んぞ全く失われる のを待つて後に行うのが常道である.けれども眩厙の ために仕事が出来ないという主訴を持つており，而も 経済的に恵まれない此の種の患者に於て，今後なお長 、期間の安静を命じる事は不可能である，か〉る場合 には多少の危険を覚悟しても，内耳摘出を行うべきで ある.社会的適示というのがそれである，かつる手術 の後に来る危険は化膿性の脳軟膜炎である. それで本 患者でも注意していたのである. 翌日は耳痛と呕吐が 2 回あつたのみだが, 翌々日には強度な前頭部の 疼痛を訴え高度の白血球増多 $(19,000)$ が見られた。 眼底はなお正常でその他の脸膜炎の早期症状も現われ 
ない. 然し第 3 日に至つて遂に脳膜炎の疑いが濃厚と なつて来た．即ち前頭部における頭痛は依然としてあ るし，眼球の圧痛も軽度ではあるが出て来て，一般状 態も少しわるい，よつて直ちに腰椎穿刺を行つた，圧 180 120, 外観が極めて軽く溷濁し, 細胞数が 270, 蛋 白量が 0.055 , 糖及び「クロリーデ」は減少しておる. 細菌は証明しなかつた。よつて直ちに脳橋槽開放術を 行なつた。

前回の手術でとり残した半規管を削除すると，後半 規管の周囲に肉芽を見た。半規管と共に後頭蓋腔の骨 壁を内耳道に至るまで削除，鳥居法によつて脳橋槽を 開放した。流出した「リコール」は軽く溷濁し，約10 ccを得た。術後俄に楽になつたと云うが，同夜は興奮 して不安状態であつた。その後 2 日間「リコール」の 排泄が少なく，時々譫語を発し，たえず頭痛を訴え， 喧澡し，度々縐帯をとり除く，睡戺をとらず項強直が 現われた。

よつて術後第 3 日，全麻醉の下に腰椎管開放を行つ た. 即ち第 4 腰椎の弓截除術を行い，約 $1.5 \mathrm{~cm}$ に瓦つ て腰椎管を切開した．可成り多量の溷濁したリコール が流出した（後日の経験でこの切開は大き過ぎた。 0.5 cmに止むべきであつた).

術後 3 日間は一般状態がなお悪く，昏崜を続け，時 に富噪状態となり大声を出し，眼球偏位，四肢並に眼 筋の症攣，上唇へルペスの出現，呼吸困難，脈搏頻且 つ小等の症状が相次いで現われ，発熱も腰椎管開放前 に比べると少しは下降したが，なお38〜 $39^{\circ} \mathrm{C}$ の間を往 来して前途暗䇾たる状態である。

所が術後第 4 日目からは漸次安静な時間が多くなり 意識もまた回復の徴を示し, 只, 時々喧梧状態とな る. 此の間腰椎管よりのリコール流出は旺盛である. そして術後第 6 日には始めて夕食を摄り，第10日には 自分で体位の転換ができるようになり，15日で頭痛が 全く消失した。此の間, 脳橋槽からのリコール流出は 極めて少量だが，腰椎管からのそれは 1 週間余に瓦つ て実に旺盛である。その後, 創腔の瘾着と共に減じ, 2 週間余にして全く停止した。

発熱は 3 週間後に著しく減じ，6週日にして全く無 熟となつた．腰椎管開放前の私の杞憂としては，その 創面の疼痛の為に仰臥位をとらないであろう，恐らく 側馷位か腹位をとるのではないか，或は腰椎管の閉鎖 が困難で何時迄もリコールが流出し続けるのではない か, 或は又, 腰部以下の末梢神経に何等かの障碍を来 すのではないか等々であつたが，それらは何れもみな
杞憂に了つた. 即ち, この患者は吾々の想像に反して 常に仰臥位をとり，且つ腰部の痛みを訴えた事がな い.之は一般症状の重篤な為もあつたろうが，とにか く仰臥位をとれるため, リコールの流出は吾々の望み 通りに好く，且つ後遺症は一つもなかつた。

要之，本患者は内耳手術後に脳膜炎を起し脳橋槽を 開放したのだが，リコールの流出が意の如くならず， 一般状態も益乃悪化し発熱も加わつて来たので，腰椎 管を開放してリコールの流出を企て，漸く治瘑に導き 得たのである. 素より一般療法として, ウロトロピン， トリパフラビン等の静注も連続施行したのではある が，リコール流出の状況と其の経過とを対比考察する と，腰椎管開放が治癒の主役を演じたものと考えられ る.

（その 2）19才，市，農

\section{主訴：頭痛，眩量並に呕気}

病歴：小児の頃から右側の難聴があり，感冒時に頭 痛と眩暈のあるを常とした。更に 2 年前よりは，右の 耳漏, '耳鳴を来たし，労働時或は感冒感のある際に耳 鳴の度を増して眩暈がある。治療を受けたけれぞも効 なく，昨日俄然後頭部の強い疼痛，呕気並に組暈感が あり，本日 2 回の呕吐を見，熱感がある意識溷濁ばな い.

所見：患者は患側耳を下に側卧位をとり，著々しく 苦閭の状を呈し，しきりに強い頭痛を訴え頭をもませ ている.

項強直軽度にあり，頭を動かすと頭や項部の疼痛を 訴える，膝蓋搐匑，その他病的反射はない，

局所々見：患側乳様突起坦面並に尖端は圧迫や吅打 による疼痛がある。外耳道は発赤し，後上方に痂皮形 成を見る．鼓膜の前下方に卵円形中等大の穿孔があ り，その縁は蒼白，滑沢，ただ上部が赤く，後下方に 泇皮の形成を見る. 鼓室岬粘膜は一般に蒼白で，後上 方部が限局性に腫脹し凹凸あり，粘液を認方る。

聴力は一般に甚だしく低下しているが，骨導は左右 に差を見ず，リンネ陰性，ウエバー患側に偏し，自発 眠振はない，迴転跟振は患側 1 迴転で $2 \alpha / 2^{\prime \prime}$ ，健側は $6 x / 6 "$, 即ち患側耳に於て機能の著々しい低下があり， 且つ 1 廽転で既に悪心を訴える。腰椎穿刺で圧 270 110 , 外観透明, 細胞数 7 , 蛋白量 0.037 , 糖量 0.665 , 染色 上何等菌を証明しない。 ワ氏反応陰性.

血液像 : 白血球数 18,000 , 核少しく左偏, 好エオジン

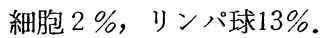

2 月 2 日（入院当日）内耳摘出，脳橋槽開放（鳥居 
法）

手術所見：骨皮質非常に厚く且つ硬く，骨蜂巣を見 ない．S状洞壁を露出したが，大した変化がない，ア ントルムは小さな腔で入口部に肉芽を容れている。そ の天蓋に脳硬膜の一部が露出し肥厚を認める．鼓室上 裔並に鼓室内は比較的に変化が少ない，顔神隆起は明 嘹でない，半規管の削除に際し僅に悪心を訴えただ け．前庭並に蝸牛殼を除去. トラウトマン三角の骨壁 を全部削除し，内耳道に近く脳硬膜を切開して脳橋槽 を開く(鳥居法). リコールの流出は少ない.

経過：その創腔よりのリコールの流出は多くなく， 健側に向う自発眼振を見，体動により眩量がある。後 頭部或は患側頭頂部に疼痛を訴える事がある。睡眠が 悪く，畕明があり，一般に興奮を示している.

第 2 日. 腰穿. 外観透明. 圧160 140, 蛋白量 0.025 糖量 0.045 , 細胞数 103 (主としてリンパ球).

その後発熱は日を追うて階段状に上昇し，術後第 4 日目には $40.9^{\circ} \mathrm{C} に$ 達した。而してこの日の腰穿では， リコールが強く溷濁し，圧 $430 〜 160$, 細胞数は無数. 蛋白量 0.33 , 䋧量 0.045 , 同日, 䁏椎管開放を行う. 手術は前例に同じ。リコールは余り出ない.

経過：翌日，腰椎管からはリコールが多量に出てい るが、ゾンデを入れると更に涌出する。意識全く明瞭 で，頭痛，呕気，眩厙等は全く消失した。 その後時々 軽度の頭痛を訴えたが，概して経過が良く，発熱は第 2 回手術後に急激に下降し始め, 約 1 週間でほほ平熱 に復し，食慾もまた次第に出て来た．腰椎管よりのリ コールの流出は甚だ良く，既に週日に及んだ. 所が第 2 回目の手術後 9 日の夜半に急に虚脱状態となり， 2 〜 3 回呕吐を催し, 意識も多少溷濁の気味がある. 脈 搏は頻且つ小，緊張不良.

よつて輸血と食塩水の静注を行い，幾分恢復した様 であるが，強心剤を連用しなければ脈搏が悪くなる。 翌日更に輸血を行い，爾後食塩水注射を連日施行した ところ, 一般状態も漸次回復して来た. 然し最も重篤 であつた輸血後 2 日間の如きは瞳孔が全く散大して， 光線反射なく，角膜も強く乾燥し，項強直著明で昏睡 を続け，時々譫語を発し，四肢に軽度の浮腫を見た。 呕吐も 1 日に $1 \sim 2$ 回あつた。

然し，か>る危険期が，輸血，その他の対症療法に よつて漸く去ると共に, 食照も漸次出て来て, 諸症状 が相次いで去り，5 日の後（腰椎管開放後第15日）に 至つて, 全く熱型の安定を見た. 腰椎管よりのリコー ル流出が甚だ多かつたのは 1 週間位であるが，なお少
量ずつの流出を見たのは16日間に及んだ。

以上述べた突然の虚脱状態は何に因るのであるかを 考えて見る. 之は炎症の増強ではなくて，恐らく腰椎 管よりのリコールの過剩流出によるものであろうか. 記して将来の参考にしたい。

最後に脳膜切開後の後療法について一言しておきた い.

頭蓋腔は勿論, 腰椎管にあつても, その開放後, 之に 排泄管或はタンポン等の挿入は絶体に避くべきである ことを主張する．次に腰椎管開放時に於ける創羫は， 縫合を行なわず，全部哆開しておくのが可い，一旦り コールの排泄が止み，経過の良好なものでは，ごく短 時日で癒着を見るからである。

腰椎管の位置は第 4 腰椎に於ても相当深く，人によ つては皮膚面より約 $10 \mathrm{~cm}$ 樑さにある.従つて，腰椎 马截除術を行い，之を開放しようとすれば，皮切線は 相当長く，少なくとも $10 \mathrm{~cm}$ を必要とする.

\section{新大に於ける治療成績の変遷に就いて。}

1. 昭和 4 年 (1929年) 鳥居の宿題報告の際に於け る本症の治癒成績

此時には14症例のうち治瘾が 4 例であり，治瘜した ものと死亡したものとの比は1：3.5である.

2. 昭和 5 年 (1930年) から 17 年（1942年）のもの （鳥居の報告）

此の際の治痹率は86例中27例であり，治癒したもの と死亡したものとの比は1 $: 2.2$ (治痛率は $31.2 \%$ ).

3. 昭和18年 (1943年) から 27 年 (1952年) のもの (新大佐藤(謙)の集計)

此の時の治瘾率は28例中10例. 治癒したものと死亡 したものとの比は1:2で $(35.7 \%)$

以上の如く大正末年迄は零であつた本症の治瘾率も 1930年頃には治癒したものと死亡したものとの比が $1: 3.5$ となり，その後の 12 年間では $1: 2.2$ 即ち治瘺率 は $31.2 \%$ となり，更にその後の10年間では $1: 2$ 即ち $35.7 \%$ 治湶率にまで上昇している。

岡山大学に於ける本症治痹率の変遷を見ると

昭和11年（1936年）の田中教授の報告では69例中16 例, 即ち $23.2 \%$ の治痹率であるが,

昭和12 21年(1937年～1946年)，岡大教室小西の報 告では, 48例中16例, 即ち $33.3 \%$ 治癒率になってい る.

即ち岡大の成績も新大のものと相似た傾向で，その 治瘑率は漸次上昇しており，大正末年頃までは殆ど不 治の病と云われていた本症も，その凡そ1/3強が救われ 
る様になつたのである.

次にこれら治瘜した症例の主な治療法を見て見る。 如何なる治療法が此の椂な輝かしい成績を挙げさせた か. 此の吟味こそ本症治療の将来に大きな且つ確実な 軌道を示すものと云えるからである。

先ず先に述べた主な観血的療法を吟味して見よう。

1. 1929年，鳥居の宿題報告中に見る本症の治瘜は 14例中 4 例であるが，これらは総て内耳摘出を行い内 耳道からリコールのドレナージをつけたものである。

2. 1942年，鳥居の報告した治痹は86例中 27 例であ り，1952年，佐藤(謙)の集計では28例中10例である. 後者は症例数が少いので，前者と同じに論じることは 出来ないが，大体の傾向を見る事は出来る. 即方前者 の治瘾率は $31.2 \%$ あるが，後者では $35.7 \% て ゙ あ り ，$ 就中, 腰椎管開放では治痹と死亡の比率が $1: 2$ から 1:1.7 と僅かではあるが上昇している，而かも，後者 は昭和 18 年から 27 年と云う彼の大戦末期から戦後の混 乱期であるから，何れの疾患に於ても治瘺率の最も低 下した時代である事を併せ考えると，平和な時代であ れば，もっと良い成績を得る事が出来たのではないか と思うのである。

それで本症治療の重点を何におくべきかと云う重要 な問題にふれておき度いと思う。

私の従来主張して来たのは，

1. 原病巣の徹底的除去.

2. 病的リコールの可及的排泄.

3. 種々の薬物療法.

こういう順序である.

そして此の考えは優秀な化学製剤や抗生物質の出現 した今日と云えども少しも変ってはいないのである。 之に就て日本耳鼻科学会々報（昭17，12月）に高原高 三教授が「耳性化膿性脳膜炎に就て」と云う題で報告 した時に，岡大の小田大吉教授が追加をしている. 此 の一連の問答は之等の問題に就いての重要な発言であ るから，それをここに摘録しておきたい，高原高三教 授は自家経験22例に就いて色々な観察を行つている が，その治瘜率は大体26〜27\%であつた. 小田教授の 追加事項を拾つて見ると，「本症の治療の核心は原病 巣の徹底的な処置とリコールの排除にある．原病巣の 処置に関して錐尖蜂巣に注意すべきは高原教授と同感 で，私共の教室に於て20例の化膿性脳膜炎の剖見に於 て過半数たる11例は錐尖蜂巣より感染しており，而も そのうち手術時に感染系路を証明し得なかつた11例の うち剖見によつて錐尖から感染した事を証明し得たも
のが 8 例ある．之等の事実は脳膜炎治療に当つて，如 何に錐尖蜂巣に注意すべきかを物語つている、リコー ルの排泄はその症例によつて適当な方法を選ぶべきで あるが，自分達の方法をもつてした最近 3 年間の成績 を追加すると， 7 例中治瘾が 4 例である。 それらは治 療開始当時におけるリコール中の細胞教は1400, 1200, 1500,3300 , であり，䁏椎穿刺針恒置法による排泄は かつて教室から報告した様に，11年の男子に於ても46 日間に14.360ccを，13才の少女に於て72日間に 23.430 Ccを持続的に排泄せしめ得た事実が示す様に，左程困 難苦痛のある事ではないけれども，私は近時持続排泄 中に完全な体位の自由を与え得るよう穿刺針に代える に輸尿管カテーテルを用いておる.」

私も本症治療の重点は失張り, リコールの排泄に置 くべきだと思うのである。

それに関連して私共の経験した示唆に富む 1 例を附 け加えておく.

それは耳鼻咽喉科（昭25年）22巻に報告してある. 耳性化膿性脳軟膜炎の 1 治験例（腰椎管, 内耳道 開放, ペニシリン大量使用)

鳥居恵二他 2 名 耳鼻科, 22,2 (昭和 25,2 )

患者：14才.女.

耳痛が始つてから極めて短かい時間に脳膜炎を起し たもので，耳の症状が出て 4 日目の朝に腰椎穿刺を受 けている，圧300，中等度溷濁があつたので，すぐに某 院に入院し, 右聴保根治手術々腰椎管開放術を受け た. その時の手術所見, 蜂巣発育中等, 蜂巣内被は浮 腫状に肥厚し上鼓室に肉芽がある，然し，どの部位か ら脳膜炎を起したか確認できなかつた。等の手術で 一時小康を得たが，第20病日頃から再び高熱，頭痛， 呕吐等があり，ペニシリン注射を受けたが効なく，第 23 病日に新大病院に移された。

入院後の経過 : すぐにペニシリン筋注 1 日 10〜20万 単位, サルフア剂の頸動脈注射, 静注及び内服, ウ口 トロピンの内服, その他を行うほか, 入院後 3 日目 （第25病日）に第 2 腰椎に於て改めて腰椎管開放術を 行ない，耳の方は根治手術に改めた。第28病日に錐尖 の開放を企て鼓室の肉芽を清掃し，鼓室岬を削除した ところ, 急にリコールが内耳道から湧出して来たの で，手術を中止した．此の手術後リコールの流出は良 好となり，腰椎管からは42日間，耳の手術創からは35 日間の長きに互つてリコールの流出があり，かくして 予後殆んど不良と思われた此の症例も遂に治瘜したの である。 
治瘾までに使用したペニシリンの総量は 910 万U筋 注サルフア剤 $64.5 \mathrm{~g}$ ， ウロトロピン $39 \mathrm{~g}$ ，その他であ る. 第 113 病日に漸く退院した。

本症例が治瘜した主な因子に対する検討. 本症例は上述の如く, ペニシリン剤, サルフア剤, ウロトロピン等の大量が投与せられた。だから一般的 に云えば，之等の薬剤が本症の治瘾に向つて，直接間 接に良い影響を与えたであろう事は無論考えられる が，一日一日の発熱の度，頭痛，悪心，呕吐等の脳症 状に対して，どれほど良い影響を与えたであらうかを 検討して見ると，ぞうもその間に密接な相関々係を見 出す事が出来ないのである. 之に反して腰椎管開放や 脳橋槽開放によるリコールの流出状況と，各日の発熱 度や，脳症状の消長との間には，甚だ密接な相関々係 が見られるのである. 即ち，リコールの流出が良好に なると，体温も下るし，頭痛や呕吐等も無くなり，食 欲や睡眼も良くなるが，リコールの流出が悪くなると 忽ち熱は上り，頭痛，呕吐等が出てくる. 即ち第 1 回 手術に於て腰椎管開放を行つたのち 1 週間はリコール の流出がよかつた。その間，熱は急に下降し頭痛も呕 気もなくなり，一般状態も極めて良くなつたが，その 後リコールの流出が悪くなるにつれて，再び発熱（最 高 $\left.40^{\circ} \mathrm{C}\right)$ 乙, 且つ脳症状も出て来て, 一般状態は段々 に悪化して行つたのである。この間，約 2 週間である がペニシリンは毎日20万U, 時に 40 万U の筋注が行わ れているにも拘わらず少しの好転も見せてはいない。 新大に入院してから第 2 回の腰椎管開放，その 3 日後 に行なわれた内耳道開放によつてリコールの流出が好 転するや，発熱の度も低くなり，脳症状も除れて一般 状態は余程良くなつて来た。此の良き経過の間に於て も，此較的にリコールの流出が不規則であつた第36〜 第43病日に於ては，また再び高度の体温上昇を見せて いるのである，此の様な事実から，本症の治癒に向つ た主な要因は, 失張り, リコールの良好, 円滑な流出 にあると考えられるのである。

次に腰椎管内に薬剤を注入する功罪については，私 共も今日迄度々発表しておるのであるが，本例に於て も又一つの警告となる材料を与えられた。

本例の治瘜が余りに遅々としているので，或は結核 性のものでないか，と云う疑問を起し，第53病日に僅 か 500 単位のマイシンと $2 \mathrm{ccのツベルフラビンを} 2$ 日 間に互つて腰椎管内に注入したのである。所が，その 後 5 日に互り熱の上昇と大腿部から脚部に放散する堪 え難い疼痛が現われた。此の樣な事はその他の症例に
もあり，リコールにも変化が来て流出が停止した。こ の様な事実からストマイ，ツベルフラビン等のリコー ル管内注入は，極めて慎重にせねばならぬ事を教えら れたのである.

次の症例報告も相似たもので，参考になるから附け 加えておく.

\section{重篤な耳性軟脳膜炎, 静挀洞血栓, 脳硬膜外膿瘍 の治験例}

許雲竜，台北医院耳鼻科，耳鼻臨床，43，9（昭和 25年 9 月)

13才，男

主訴：高熱，意識障害

病歴：1950年 2 月20日，突然悪感戦慄を伴う高熱， 眩厙，悪心，呕吐を来たし，マラリアとして治療をう けていだ。

2月24日，右乳様突起部に疼痛があつた。その翌日 項強直，3 日遅れて全身痙攣，意識溷濁を来たしたの で，初めて耳性頭蓋内合併症が疑われた。リコールの 所見. 圧が高く，洭濁し，双球菌，桿菌を証明した。 ペニシリン，ストマイの筋注並に腰椎管内注入が行わ れ，やや軽快を見せたが，食欲不振，意識溷濁などの 全身状態は依然として除かれない。それで 3 月 7 日に 耳鼻科に入院.

所見 : 体温 $38^{\circ} \mathrm{C}$, 脈搏 120 で微蒻, 顔面蒼白, 意識 溷濁あり，瞳孔反射遅鈍，項強直並にケルニヒ症状あ り.

局所々見 : 右外耳道に罒臭ある分泌物あり，鼓膜殆 んぞなし，後上部に真珠腫塊あり．X線写真で右は一 般に溷濁し，乳様洞，S 状洞骨壁の像を認め難い。

リコール所見 : 圧210, 強度溷濁, 細胞無数, 殆んぞ 膿球，クエツケンステッドが (\#)，グラム陽性双球 菌, グラム陰性桿菌も証明した。

血液所見：白血球 11,800 (桿状核 $44 \%$ ，分葉核 $22 \%$ リンパ球30\%，単核細胞 $4 \%$ ).

尿ウロビリノーゲン陽性.

手術 : 入院，中耳根治手術を施行.

その所見. 乳突外骨壁は薄く, 乳様洞及びその附近 は膿汁と真珠腫塊，肉芽，壊死組織等で充満され，そ の入口部は真珠喠塊で閉鎖され，鼓室への排膿が遮断 されている．S 状洞骨壁はカリエースで一部欠損．小 脳硬膜は広く浮董状を呈し，一部肉芽で覆われてい る. 後方は後頭部まで下方は乳突外表全部を削除し $S$ 状洞の上後部をも露出した．S状洞は硬い索状物とし 
て触れ，試験穿刺で血液も膿も証明し得なかった。側 頭葉脳硬膜も発赤腫脹しているので, 乳様洞天蓋, 鼓 室天蓋，側頭鱗の骨壁等を広沉に削除した，骨性迷路 は瘦孔を認めないが，温水刺战で眼 振が出ない. 即 ち，機能疫絶と断定して三半規管を削除した。内耳腔 は肉芽で充され，更に錐体後面に沿うて錐体尖端の方 向に入り，そこに約20ccをを入れる膿瘍を発見した。 之 を拭き取るとリコールが流出して来た。詳細に調べて 見ると内耳道直後部の脳硬膜に直. 経約 $0.5 \mathrm{~cm}$ の㾇孔を 認めた。

更に蝸牛殼の開放を企てたが，患者の全身状態が悪 いので手術を止めた。

手術後, 輸血 $100 \mathrm{cc}$ 及び一般薬物療法を行い, 又腰 椎穿刺を頻回行つた.

その後，な溦熱が続くので，3月18日に腰椎弓截 除術を行い，髄硬膜を約 $0.5 \mathrm{~cm}$ 縦に切開した。約 10 日 後に切開創が瘜着したので手術創からリコールを穿刺 採取した。使用薬剤は次の通り。

ストマイ使用総量 $66 \mathrm{~g}$

水溶性ペニシリン総量 2,472 万単位

ペニシリン油 (30万単位/cc) を数cc.

5 月 2 日全治退院.

考按 : 化学療法, 抗生物質の進歩発達は耳科領域の 治療に寄与すること多く，最近側頭骨含気蜂巣(山下) の手術率の著明な低下も之による。

一方，これらの過信濫用により早期手術を要する症 例にも姑息的療法を行い，為に急性炎症がマスクされ て遷延慢性化され，起炎菌に抵抗が出来て，再発した り，重篤な合併症を起す事があるようになつた。

本症例も 9 日目に耳性脳軟膜炎と判つたのにペニ シリン，ストマイ等の注射に終始し，病態が悪くなつ て始めて吾々の手に渡り16日目に手術を行つた。

抗生物質の卓効は認めるが，既に之等薬剤の作用が 及ばないものには，適時に早期手術を行い排膿を計る 事が不可欠である。

腰椎穿刺の反覆施行は病が重くて長引くと思われる 場合には，煩わしい，よろしく持続的排泄法を採るべ きを痛感する。本症例は子供で安静を保ち得ないか ら，田中，小田氏法よりも鳥居教授の推奖する腰椎弓 截除術を採つた。

結語 : 本例は中耳根治手術，脳橋槽，腰椎管開放を 行つてリコールの持続的排泄を計る一方，サルフアメ ラジン $21 \mathrm{~g}$ ，水溶性ペニシリン 2,472 万単位，ペニシ リン油300万単位，ストレプトマイシン $66 \mathrm{~g}$ の薬物療
法を併用してようやく治痹せしめ得た，新化学療法， 抗生物質の進歩，発展は鳘異に值する分，その効力を 過信して，必要な早期手術の時期を失してはならない 事を強調したい.

化膿性脳膜炎の統計的観察

（其の 1）- 一般的観察

三林茂雄 北越医会誌 59, 5，(昭和 $19 ， 5$ )

観察材料

教室に於けるもの，大正 15 年から昭和 17 年に入院治 療を受けたもの. 64例

本邦に於て報告された同期間の症例 161 例

\section{観察成績}

\section{年令との関係}

教室のものでは，10才台が最も多く，10才から20才 が之に次ぎ，40才台はそれに次ぐ．

日本と外国のものを綜合して見ると，

1） 10 才〜20才

2） 40 才台

3） その他

即ち学令期から少青年期に多い. 乳幼児，壮年には 少ない.

\section{年令と予後との関係}

教室では 40才以下の46例では治瘜が18例 (39.1\%) 40 才以上のもの，18例中治瘾は只 1 例。

日本人全体で見ても40才以上のものは予後が悪い。 原病巣之の関係

a. 原病巣之本症の発生頻度

急性中耳炎が慢性中耳炎より多い，然し年令別に見 ると，

40才以下．急性中耳炎＜慢性中耳炎。

40 才以上. 急性中耳炎 $>$ 慢性中耳炎.

40才以下のものでは急性中耳炎と慢性中耳炎との差 は少ないのであるが，40才以上のものでは二者の比率

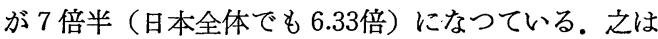
主としてムコーズス菌による中耳炎が40才以上の人に 多い事に因る。

\section{本症の発生機転}

脳膜への感染系路としては，乳様突起の骨壁，内耳 錐体尖端，その他の病巣，例えば脳膿瘍又は洞血栓等 が挙げられるが，手術所見又は剖見所見によつても， なおその感染系路を明らかにし得ないものが少くな い.

\section{教室の統計}

広沉に侵した真珠腫 20.5\% 
乳様突起尖端内の色々な病変 $39.8 \%$

$\mathrm{S}$ 状洞血栓 $8.2 \%$

内耳周囲の蜂巣炎又は内耳炎 $23.3 \%$

錐体尖端に病変のあるもの $2.7 \%$

脳膿 演 $5.5 \%$

以上のうち乳様突起或は $\mathrm{S}$ 状洞血栓なぞ，乳様突起 内に変化のあるものを一括すると， $48.0 \%$ となる.

内耳性及び鼓室性のものは，慢性中耳炎に続発する ものが多い，錐尖蜂巣から感染せるものは，急性中耳 炎に続発するものが多い。

\section{治療法}

a. 原病巣に対する処置

根治手術と内耳手術を行つたもの

治瘾率 教室 $35.0 \%$

日本 $37.9 \%$

中耳の根治手術のみを行つたもの

教室 $28.9 \%$

日本 $55.8 \%$

中耳の単削開のみでは

教室 治瘜例 なし

日本全体 $23.3 \%$

全く手術せぬもの

教室 治瘾例 なし

日本全体 $18.8 \%$

腰椎穿刺を反覆したもの

教 室 $42.8 \%$

日本全体 $47.9 \%$

脳橋槽開放

教室 22 例中 5 例 $(22.7 \%)$

日本全体田中, 小田 1 例（昭 5 年）

田中，兵，長倉 1 例（昭 8 ）

岡島, 大島 1 例（昭12年）

腰椎呀刺針恒置法

文朝で見ると２9例中18例の治瘜がある（62\%）

教室では， 7 例中，目的を達せず中途で腰椎管開放 に変えたものが 4 例， その他の 3 例のうち 1 例が治瘾 した.

腰椎管開放を行つたもの

治㾉率 $50.0 \%$ ， 尤も之は初めに腰橋槽開放を行 い，その後に腰椎管開放と同時に内耳手術を行つたも のである。

全体の治瘾率

教 窒 $29.7 \%$

日本全体 $23.6 \%$
外 国 25.7\%

\section{化腹性脳膜炎の統計的観察}

（其の 2） 血液並びにリコール所胃と予後

三橋茂雄 北越医会誌 59.7（昭和19.7)

血液所見 吾が教室の64例中，血液検査を行つた 49 例を資料にした。

結論：刍血球総数及び中性好細胞の増加，リンパ球 の減少，エオジン好細胞の減少又は消失，核型左方推 移，等は共に重篤な頭蓋内合併症の警告であり，特に 発病より48時間以内に既に此の種の顕著な変化を証明 し得る事は血液検査が，本症の早期診断に極めて重要 だと云う論拠を与える。初期からエオジン好細胞の消 失，リンパ球の著減があり，同時に核の左方推移の高 度なものは，予後が大低不良である．経過中に白血球 絵数，中性好細胞が漸减し，リンパ球の漸増するもの は予後が良い.エオジン好細胞の出現又は増加, 幼若 細胞の減少等は予後好転の徴である. 就中, 経過中の リンパ球及び中性好細胞の消長は予後の判定上重視す べき所見である。

\section{リコール所見}

64例中比較的詳細なリコールの検査を行つた 52 例を 選び観察した。

結論：リコール圧の亢進, 外観の溷濁, 総蛋白量の 増加，糖量の減少，細胞数の増加，ノルモ・マスチッ クス反応等, 何れの所見も本症の早期診断に有力な根 拠となるが，特に総蛋白量の増加及び多核白血球を始 め細胞数の増加は最も重要で，リコールの検索上ゆる がせに出来ないものである. 更に予後判定上最も信頼 のおけるのは総蛋白量の増減で, 之が他の所見の消長 に拘らず，漸次減少し正常值に復帰せんとする傾向が あれば，之は予後の良い徵と見做して可い，細胞数の 増減もまた予後判定の上に相当な手がかりとはなる が，前者ほどの確実性はない，リコール中に細菌の証 明されるものは甚だ悪い，脳膿瘍と合併した本症の診 断はなかなか困難であるが，それにはノルモ・マスチ ックス反応の特有な曲線が有力な参考になる。

化膿性脳膜炎の原因としての内耳炎に就いて

鳥居恵二 昭和 4 年, 日本耳舅科学会総会の宿題 「内耳炎及びその合併症」の中から拾う。

Göarke の.「耳性脳膜炎の伝染系路について」と云 う論文中，「耳性脳膜炎の伝染系路のうち，その頻度 に於て，また臨床的意義に於て，第一位を占めるもの は内耳である。実に内耳と頭蓋腔との交通は，中耳と 内耳のそれに比べて遥かに自由である．かかる解剖的 
関係から云えば，内耳は実に頭蓋腔の一部分なりと云 うを妥当とする. 従つて，内耳内の炎症は，頭蓋内合 併症の第一階梯として見るべく，耳性脳膜炎の治療に 当り，内耳炎を有するものと，然らざるものとは，そ の治療の根本に於て相異ならざるべからず」と云う交 章を引用し，自分もまた全く之に同感であり，内耳炎 は単に中耳炎の一合併症と見るべきでなく，極端に云 えば，内耳炎即脳膜炎と見なければなら事を強調し た.

而も当時の日本に於ては未だ内耳炎の臨床に関する 系統的な研究がないので, 自分はそのパイオニアたら んと決意し，乏しき経験を省みず敢て宿題報告のテー マとした。

内耳炎加ら脳腔に行く伝播系路.

炎症が内耳より脳膜に伝播する系路は内耳道が最も 多く, 内リンパ管及び霆, 外リンパ管, 腐骨の順であ る. 外リンパ管は管腔の狭小なために早く狭窄を起 し，むしろ炎症の伝播を阻止することが大きい様に感 じられ（後になされた広谷常治の微細構造研究を見れ ばその事が首肯できるのである), 内リンパ管及び囊よ りの合併症は, 小脳膿癔と脳硬膜内外の膿瘍が多数 で, 脳膜炎は只 1 例である.

Zange の228迷路炎屋の研究によれば

1. 炎症の内耳道まで波及せるもの $1 / 2$

2. 炎症の内リンパ管及び震にまで波及せるもの $1 / 4$

3. 咨症の外リンパ管まで波及せるもの 116 脳内合併症を起したもの

1. 内耳道経由のもの 2/3

2. 内リンパ管及び震経由のもの $1 / 5$

3. 外リンパ管経由のもの $\quad 1 / 28$

\section{内耳周囲炎に就いて}

先に私は中耳加ら内耳一の炎症伝播系路の項に於 て, 日本の交献では, 内耳周囲炎の多い事を述べたが 内耳炎や脳内合併症を取扱う際に，此の内耳周囲の炎 症に深い注意を払う事の重要性を強調したい。

炎症が内耳周囲の骨質或は骨胞を伝つて錐体尖端の 方向に進み, 色々な脳内合併症を起すことは想像に難 くないのに，今日迄かかる症例の報告されたものは至 つて少い. 之は内耳手術例の未だ多くない事, 脳膜炎 尼の剖見例の少ない事, 乳様塋起や錐尖開放手術の際 に，此の部が死角に相当するため，究明せられずに済 まされる事が多い等に因るのであろう．私共が行なつ た少数の内耳手術例に於て，内耳周囲の炎症が主体と なり，二次的に内耳炎を起し，或は脳内合併症を起し
たものの而かく少くない事を想像し得た. 即ち，非合 併嶈夜性内耳炎の数例に於て, 内耳周囲に於ける变化 の甚だ高度なものを見た他, 脳膜炎を起した 1 〜の 症例に於ても, 内耳自身には軽度の变化しか想像せら れないのに，内耳周囲の化膿が強く，それが錐体尖端 附近にまで波及せるものを見た。

\section{迷路周囲炎に就いて(迷路周囲炎の研究，その 2 )}

鳥居恵二 耳喉科 2.6. (昭和 1.6 )

Jm. Smith は迷路炎の症状たる眩最, 悪心, 呕吐 の如きものは，また，迷路周囲の感染のみによつても 起り得るものであるから, 真の迷路炎とかかる迷路周 囲炎を判別する事が重要である，後者は主に後, 横半 規管周囲に在る骨胞の感染で, 迷路は刺㦸状態にあ る. 而もかかるものには迷路手術を行う必要なく，根 本的に中耳の単削開なり根治手術なりを行う事によつ て救い得ると云う。

私の内耳性脳膜炎第 2 例の術時所見を見るに，半規 管周囲の骨質が甚だ脆弱で, 出来る限り之を清掃する と, 後半規管の後方に廔孔を認めた. ゾンデの挿入は できるが，此の部が狭くて，半規管を除去しなけれ ば，より樑部の清掃が不可能なので, 手術を中止した。 所が，その後の経過が 面白くなく，分泌物も多量な ので，第 2 回の手術を企てた. 半規管を義性にして前 回の瘦孔を追求し，破瀤された骨質と肉芽を除去しな がら手術を進めて行くと，遂に錐体尖端に近ずき，そ こに小さい腐骨片を入れていた. 此の手術後に局所の 分泌が急に減じ，一般状態も良くなつて遂に治痹し た。

グラデニゴー症状群のうち, 或ものでは, その炎症 が迷路周囲の骨胞をつたつて錐尖に行つたと想像され るもののある事は，私が先に耳鼻咽喉科 (2.3)に「我 が国交献に現われた耳性外旋神経麻潧を伴えるものの 統計的観察」で述べた所である.

如何なる炎症なるを問わず，之が拡大して迷路の方 向に進む時, 若し迷路周囲の骨質が之に侵され易い構 造を有つなら，比較的に，ょり緻密な骨款で包まれて いる迷路自身を侵す前に，まず，その周囲の軟い骨質 を侵蝕すべきは自明である、アントルムより錐体尖端 に至る間には迷路並びに内耳道等がある。殊に迷路の 在る部分では錐体後面との間が甚だ狭い, アントルム と錐尖とをここで遮断した形になつている。従つて, 炎症が一度迷路周囲及びそれより深部に波及せんか， 外方に向つての排泄は甚だ悪く, 殊に中耳の炎症が慢 性或は緩慢性のもので, 真珠腫, 肉芽又は骨新生等によ 
つてアントルムとの交通が阻害される場合には，その 深部に封じ込まれた化膿巣は自然，頭蓋腔に向つて進 むか，或は遂に迷路自身を侵すほかないであろう。

かく考究来るとき，迷路周囲に於ける炎症は，岑が 迷路内に波及する危険の他に深部頭蓋内合併症に向つ て，甚だ意義の多いものと云わねばならない。

かかる症例についての治験を后めるためには，一は 臨床例を集める事，他は迷路周囲より錐体尖端に至る 迄の正常人の解剖的関係, 特にその蜂巣発育の状態, その他を明らかにする事が必要である.

私は今日までの文献に現われた症例を集めて見た。

Haymann（1928年）は迷路周囲炎より脳膜炎を起 した興味ある3 例を報告している。

\section{II. III例 Haymann}

IV 例（鳥居の第 1 例）

V例 L. Kraus(一連の側頭骨組織検査を行つた).

$\because$ VI Fräsel の第16例

VII G. M. Smith の例

䜣 鳥居の第 2 例（前例に相似たもの）

以上の 8 例のうち, 軽きは根治手術後に於てなお頑 固な頭痛を訴えているが内耳は只, 機能の六進を示し ているに過ぎめ. 再手術をして見ると半規管周囲の骨 質が甚だしい炎性侵潤と破壊を蒙つている。 それらを 徹底的に清掃したら，頓に頭痛の消失を見た。 その他 のものも，多くは，迷路周囲炎で殊に蝸牛下部より錐 体尖端に互つて広沉な化膿巣を見, 或る例では, 之が 直接錐体後面に至つて脳内合併症を起し，或る例で は, 内耳の一部を外方から侵して, 汎内耳化膿を惹起 し，それより更に内耳道を伝つて脳膜炎を起したもの がある. 吾々が将来注意して或は臨床的に或は剖見か ら，かかるものを収集すれば，而かく少ないものでは ないと信ずる。

以上の様な臨床例に就いての観察のほか，かかるも のの発生に関して, 有力な知見を与えるものは, 健康 人について解剖的関係を明白にすることである.

従来; 鼓室より後方の骨蜂巣その他に関する解剖学 的研究は多くあるが，迷路周囲及びそれより深部で錐 体尖端に至る内部構造について，之を系統的に研究し たものは殆んどない様である。

私は迷路周囲炎とも名付くべき上記症例の如き, 或 はいわ゙ゆグラデニゴー症状群の如きものに就て，い ささか知見を加えんと欲し下田(伯)に此の研究を委ね た. その研究成果を綜合すれば，迷路周囲から錐体尖 端に至る沦骨胞办極めて顕著に発育せるもの，或は後
方から内耳道の上を通つて骨胞の伸びているもの，内 耳の下部に赤色髄又は脂肪髄を見るもの，或は孤下窩 が極めて長く錐体内に侵入せるもの，或は錐体尖端内 にある骨胞とガッセリー神経節との間に多くの骨吵の 存するもの等を見た。

かかる像を見れば，先にのべた臨床例の如きものの 発生は，決して偶然でない事を知るのである。

耳性化膿性脳膜炎の早期症状に就て。

深瀬(亮) -耳鼻臨床 29.2. (昭和9.8)

吾乃は本症の初期症状に就て周到な観密を行い，疑 問をもちうるいささかの症候でもあれば，直ちにリさ 一ルの試験穿刺を行い，診断の早期確定に努力しなけ ればならぬ. 然るに，その初期症状に就ての吾々の知 識は未だ決して豊かだとは云えない。

これら初期症状に関する結果の文献を見るに, Güttich は顔貌苦悶の状を呈し, 種々の処置に対する 過敏，腓腸筋の過敏をも見たと云う。Aroin は三叉神 経痛及び後頭結節の自発痛を，...Alexander は睡眠障 碍, 頭痛, 脈搏の緩除(絶対的, 相対的), 皮膚の知覚 過敏, 腱反射六進等を, Anblus は迷路の刺㦸方進, 光線及び音響に対する感覚元進等を, Knick 及び Kurenkampf らは截域後頭膜の圧痛を, Zange は 頸部運動時に於ける逃避的抵抗, 頸部緊張感, 後下䫛 窩の圧痛等をあげている。

即ち本症の早期症状としては, 頭痛, 悪心, 呕吐, 三叉神経痛, 筋痛, 後頭結節の自発痛等の他に, 精神 の異常光奮, 知覚過敏, 眼球, 後下靧窩及び項部等の 圧痛, 腱反射の克進, 遅脈等をあげているものが多 w.

私共は比較的精密な観察を行つた17症例について， 綜合的に記述した。

\section{1. 自覚症状に就いて。}

全身違和の他に, 頭重感, 頭痛, 悪心, 呕吐, 眩量 耳鳴，睡眠障碍，まれに複視等があげられる。就中， 頭痛, 悪心, 呕吐等は最数で, 頭痛は17例中15例 悪心，呕吐は14例で殆んど大多数を占めている.

頭痛は, 早期に於ては, 患側の偏頭痛として訴えら れるものが最も多く, 側頭部, 前頭部の順序である. 後頭部に限局し，又は頭部全体に迌を訴えるものは， 発病後日を経た者に多い, その他, 患側の顔面痛, '又 は項部痛として訴えるものもある。

要するに，早期に於ては，比較的限局した部位に頭 痛を訴えるが，日を経るに従つて全般的になる，而か も前者では患側の側頭部及び前頭部なる事が多い.之 
は正に炎症巣拡大の状態を患者自身の口を介して吾々 に教えるものの様である。

悪心及び呕吐，特に食事と無関係に来るものは，早 期に於ける症状として重視すべきで，吾々の症例に於 ても，殆んど大多数を占めている.

睡眠障碍は，頭痛の為のみならず，脳中枢の興奮が その原因をなしている様である，従つて早期症状の一 つとして注目すべきであり，特に小児に於てそ忌うであ る.小児は自ら不眠を訴えないが，吾々が注意深く観 密していると，深夜目をパチパチ開けている事が稀で ない.

顔貌に就いて，本症に於ては顔貌が極めて厳肃で焦 燥の色が濃く, 眼光湿潤にして光沢を帯び，一見して 病症の容易ならざるを感ぜしめるものが多い，脳膿瘍 の多くが，無欲状，遅鈍状を呈するもの多きと比較し て, 格段の相違である. 就中, 比較的早期て於て之が 見られる。

4. 精神 (意識), 状態について.

前節に述べた様に，本症に於ては精神の興奮を見る

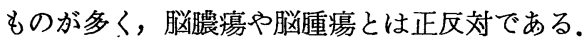

5. 眼の症状について.

光線反射遅鈍のものは, 早期のものでは 8 例中ただ 2 例に過ぎぬが，中間期のものでは 5 例中 3 例で，日 時の経過と共に，その度の増強を見るものが多い．

Blau は35\%に Phlane は30\%に眼底の変化を見た と云う。眼底の変化は脳膜炎症状の発現以前に見るこ とがあると云う者があるが，之に反対する者も少くな い.

Pitt は化膿の進行しない脳膜 炎に於ては，眼底に 何等の変化をも見ないと云う。が Knies, Zaufar ら は之に反対し，Schow は主として急激な経過をとる もの，或は連鎖状球菌性脳膜炎に之を見ると云う。

吾々の症例で，眼底検查を行つたものは極めて少数 であるが，早期のもので変化を認めたのは 3 例中 1 例 中間期のもの 1 例中 1 例あつた. 即ち眼底の病的所見 は，早期に於ても認められるもののある事を記憶せね ばならぬ。

眼球の圧痛は早期から既に陽性なものが比較的多い 事も注目すべきである。

\section{6. 後下額窩の圧痛について}

眼球の圧痛と共に本症状が比較的早期に於て見られ る事も注意すべきである.

7. 特発眼振について

吾々の症例で，早期のもの 8 例中 4 例，中間期のも
の 5 例中 1 例，ほほ完成期のもの 4 例中 1 例に之を見 た、けれども，之等はすべて迷路性のものの様で，脳 膜炎に起因したと考えられるものは 1 例もなかつた。

8. 睖蓋腱反射亡，その他の病的反射について

反射としては膝蓋腱反射，膝蓋及び足の反跳，バビ ンスキー,メンデル，オッペンハイム症状等を検查し た. 滕蓋腱反射の六進は早期のもの 8 例中 4 例に於て 見た。即ち本症の早期に於ては，䎑蓋腱反射の克進を 見るものが多く，病势の進行と共に減弱又は消失を来 たす。

その他の病的反射のうち，早期に於て雯々見られる ものは，足反跳で，その他のものは中間㥍以後に於て 現われ，早期には見られない。

\section{項强直について}

これは脳膜炎の完成期に近ずくに従つてその陽性率 を高め，早期に於て之を証明し得るものは少ない，軽 度なものは，単に前屈時に一種の抵抗を感じさせるも の，或はその際に軽い頭痛を訴えるものもある。，それ らのものを加算しても，なお早期に陽性のものは極め て少数である. 従つて本症の診断にこの症状を重視す ると，早期のものを看過する事になる．本症状が明白 に出るのは，既に遅い時期のものであると考うべきで ある。

10. ケル二七症状

この症候が陽性であるものは，脸膜炎が既にに完成 期に入つていると見做すべき事洨諸家の一致せる意見 である，韋々の症例に於てもそうであつて，項強植よ りも更に遅い時期に陽性となるものが多い.

\section{1. 腹壁の陥凹について}

腹壁の陷凹は中間期の 5 例中 3 例；完成期の 4 例中 2 例に見られた。

\section{2. 体温について}

Körner, Brünberg らによれば，本疾患の発熱の 特徴はない，遷延性のものは，平熱又は正常以下の熱 型を示す事があると云つている。

Bregrau. Schülze. Stacke.らは既往の体温の上昇 を自覚したが，その後無熱だつたものを報告しでい る.

私共の症例中にも殆んぞ無熱のものが 2 例あつた。 従つて発熱に絶対的の信頼をおいてはなら好.

\section{3. 体温と脈搏数との関係}

掘脈，脳膜炎の早期には迷走神経を刺戟するなめ： 遅脈を見る事がある。芝本症の早期診断に有力な根 拠を与えると主張する者に Alexander,，継見，素須 
らがある。

吾々の症例でも遅脈を見たものは，早期のもの 8 例 中 4 例，中間期のもの 5 例中 2 例，完成期のもの 4 例 中 2 例ある. 即ち遅脈は早期に於て見る事が多く，完 成期に近ずくに従つて減少の傾向がある.

その他，早期症状として患側の難聴増悪，健側の突 然難聴を報告しているものが少くない，吾々もまた少 数の経験をもうている，注意すべきである.

以上を綜合すると，他覚的症候のうち, 項強直, ケ ルニヒ症状，足反跳，バビンスキーその他の病的反射 は; 脳膜炎が既に相当発展した後に始めて現われる症 状である，従つて，これら症状の発現を待つて本症の 診断を下すならば，その治療は既に遅きに失する事を 忘れてはならない.

早期症状として特に注目すべきほ自覚症状のう ち, 患側の側頭又は前頭部に於ける疼痛, 食事に無関 係の悪心呕吐, 矓量, 耳鳴, 睡眠障碍等であり, 他覚 的症状としては, 顔貌が厳肃で興奮を示し, 眼光が湿 を帯びて光輝あること，総ての感覚に対して煩る過敏 であること. 眼球並に後下顎窩; 後頭結節又は後頭下 窩等の圧痛, 頭部前屈時の逃避的抵抗 膝蓋腱その他 の異常光進, 遅脈, 瞳孔不同, 眼底充血等を注目すべ きである。

就中, その特異な顔貌, 眼球の圧痛, 瞳孔不同, 光 線反射遅鈍，頭部前屈時の抵抗，遅脈等はその自覚症 候と相俟つて本症に対する知惑を喚起せしめるもので ある.

発熱は多くの場合, 特に早期に於ては, 余り重きを おいてはならない.

早期症状についての補足.

\section{耳性化膿性脱膜炃一}

金野(孷) 耳喉科 22.8. (昭和25.8)

羞明が時に極めて早い症状として現われる事があ る. 反対側下肢の特有な外転及び外旋を挙げている者 もある. 又雯又雨側眼瞼の運動失調が見られる.

化膿性脳膜炎臭診断及び治療に関する研究

其の1. 血液像並びにリコール所見より見たる化

\section{膿性脑膜炎之類症鑑别}

前田鏮次郎，グレンツゲビート 5. 11.（昭和6. 11）

吾が領域, ‘特に頭蓋内合併症に於ては，血液像並び にリコールの所見が, 疾病の診断及び予後決定の上 に，甚だ重要な役割を演ずる事がある．例えば，脳膜 炎と内耳炎，或は脳膜炎と脳膿瘍の如き，鑑別の甚だ 困難な場合がある，之等が血液像，或はリコール所見
から，果して鑑別し得るや否に就ては，これまで多数 の研究業績が発表されているが，未だ今後の検索に待 つものも少なくない，比較的稀な之等の疾患に就て は，多数研究者の協同的努力に待たねばならぬ。

\section{観察方法}

観察例はすべてが当科の入院患者であつて，耳性又 は鼻性疾患の経過中に頭蓋内合併症を起したもの，そ の手術前後, 少数例にあつてはその後の長い経過に瓦 つて観察を行つた.

\section{観察成績}

内耳炎の症例は，その手術前後の所見から診断の確 定したもので，而かも未だ脳膜炎の症状を見ないいわ ゆる非合併内耳炎のみである。横洞周囲膿疸例は，そ の手術時に膿瘍を認めたものである．脳膜炎及び脳膿 癔例の多くは急性又は慢性の耳炎から遂に上述の合併 症を起したもので，臨床並びに剖見によつて診断の確 定したものである.

\section{非合併内耳炎 9 例}

横洞周囲膿瘍 7 例

脳膜炎 11例

脳膿瘍 7 例

\section{血液像についての考按}

以上の諸症例について見るに，非合併内耳炎例にあ っては，その漿液性炎たると，化膿性炎たるとを問わ ず，またその急性炎たると然らざるものとを論ぜず， 白血球総数の増加, 中性好細胞の増加, 核の左偏, リ ンパ球の減少を認めるものがある. 然し, それらは極 めて軽度の変化であつて，エオジン好細胞の消失など はない。

横洞周囲膿陽例にあつては, その炎性变化の高度な るものにのみ, 高度の白血球増加を見たが，中性好細 胞並びにリンパ球には概ね異常がない，只，エオジン 好細胞の減少せるものが多く，その全く消失せるもの が 3 例あつた. 本症例群に於けるやや特異な所見であ る.

䋞膜炎例にあつては，その 2 例に於て白血球総数が 1 万に達しなかつたけれぞも, 漿液性炎, 化膿性炎と もに 1 万を起えるのが普通で，各合併症中その最高值 を占めている。

化膿性炎について見るに，中性好細胞の増加，核の 左偏は一般に甚だ高度であつて，リンパ球もまた激減 するものが多く，予後の不良なるものにあつては，そ の変化がいよい上著明である. エオジン好細胞は予後 の不良なものに於ては減少又は消失し，予後可良なも 
のに於ては之に反する. 以上各細胞の種類に於ける変 化は，脳膿瘍にあつてもまた等しく現われる所見であ るが，後者にあつては，白血球増加が䋞膜炎のように 高度でない. 即ち, これら頭蓋内合併症に於ける各例 に就いて，之を血液像から見ると，一般に，その最も 高度なのは，化膿性脳膜炎例であつて，脳膿瘍例が之 に次ぎ，非合併内耳炎，及び横洞周囲膿煌例は之に劣 る．而してその経過を追うて観察せるものを見ると， 白血球数は階段的の規則正しい増減を示すものではな く，可成り著しい動摇を見る.

可艮なるものにあつては，漸次中性好細胞の減少， 核变位の恢復, リンパ球の増加及びエオジン好絊胞の 出現及び増加等を見た。

之によつて之を見れば，これまで報告された如く， 白血球数増加の変動のみによつて, 合併症の有無又は 予後を論ずる事は出来ない，特に脸膿瘍例に於て，然 り. Urbantschitsch は，「ほほ正常値にあるもので 既にその病変の成立を見るものがある」と述べている が，私の症例に於ても同様なものがある．只，脳膜 炎，特にその化膿性炎では一般にその変化が特に顕著 であつて，横洞周囲膿湯，非合併内耳炎にあつては， その変化が遙かに軽度である. その予後の推定に就い ては，一般に白血球総数の増減の他に，中性好細胞の 消長，核偏位の状，リンパ球並にエオジン好細胞の増 減等，換言すれば，白血球の種類についての観察を も，併せ行う事を怠つてはならない。

\section{リコール所見についての考按}

非合併内耳炎では多くは全く正常の範囲にある．横 洞周囲膿瘍例にあつては，他の所見がほほ正常なの に，液圧のみがやや高い様で，150乃至200以上を示し ている. 炎症の高度なものに於ては両者とも蛋白量の 軽度の増加を来たしている. 化膿性䋞膜炎例では, 俄 然上記の如きいろいろ病的所見を旺するもので，脳膿 瘍例でもその末期に於ては之と全く相似の変化を示 し，リコールの所見による両者の判別は甚だ困難であ る. 今，余の経験例を対象として，少しく之等の点に ついて述べて見よう。

\section{1) 液 压}

化膿性脳膜炎にあつては，3 例を除き，すべて200以 上を示すが，脳膿瘍例に於ては，正常圧か，時にはむ しろ低圧の事がある. 但し液圧は種々な因子が加わつ て変化を来たすものだから，之に重要な意義をつけて はならない。

2) 外 観
化膿性䋞膜炎にあつては，いろいろな程度の溷濁を 見，炎症の進行につれて，その度がいよいよ加わる。 脳膿瘍にあつては，少なくともその初期に於ては，透 明なのを常とする。

\section{3) 糖 量}

化膿性脸膜炎に於ては，一般に激減し，只，痕跡を 示すに過ぎないものがあるが，脳膿瘍例にあつては， 同じく減少を来たすも，その度化膿性脳膜炎に比して 遥かに低い。

\section{4）蛋白質量}

両者共に正常以上の量を示し，グロブリン反応は何

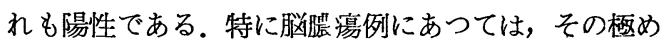
て初期に於いて, 他の所見に比し, 或は他の所見に先 立つて，既に，その増加の著旫なものが多い.

\section{5） 細胞数及び種類}

化噥性脳膜炎に於いては，総てその増加が甚だ著明 で，その多くは多核白血球である．然るに脳膿瘍例に あつては，之に比べて一般に甚だ軽度に止り，その多 くはリンパ球である.而して, 特に注意すべきは, 細 胞数と蛋白量増加との相互関係で, その早期に於い て, 前者にあつては, 組胞数の増加及び蛋白量の増加 を見るが，脳膿瘍にあつては蛋白量の増加に比し，細 胞数の増加が極めて少ない.ノルモ・マスチックス反 応も雨者の判別に少からざる根拠を与えるものの様で ある。

リコールの所見と予後との関係，その経過を追つて 観祭したものを見ると，（例数が少くてハツキリ云え ないが）一般に液圧が漸次上昇するものは，その下降 の傾向あるものよりも予後が不良である.

糖量の激減又は漸减を示すものも又同様である。 細胞数に就いて云えば，減少するもの，又は恢復に 当つてリンパ球の増加を示す如きものは，予後可良で ある．蛋白量の漸次増加し来るものも，概して予後が 不良である.リコール中に病源菌の証明されるもの は，私の症例にあつてはすべて死の転帰をとつた．然 しリコール所見の恢復期に入り他の所見は既に正常に 復しているのに蛋白量のみ独り正常值に帰らないで， 極めて長い経過の後に漸く恢復するものもある.

\section{総 括}

私の観察せる頭蓋内合併症の諸症例に就て，血液像 並びにリコール所見に就て見るに，個々別々の所見の みを以てしては，一特にその早期に於ては一診断並び に予後の決定に資する事は出来ないけれども，此の両 者を併せて，経過と共に観察を行えば，判定に少なか 
らざる根拠をつかみ得る．今後之が検査方法の進歩と 共に益々その重要性を加えて来るであろう.

\section{本症の基礎的泣に実験的研究}

解剖関係

\section{側頭骨の組織解副学的吥究}

下田伯一 日耳鼻“38.2 (昭7.5)

\section{第 1 篇 側頭骨の含気蜂巣系統に就いて}

聴器の解剖については，古くより幾多の学者が，或 は発生学的に, 或は形態学的に研究している.これら の研究の跡を見るに，多くは唒骨についての調査，或 は色々な物質を入れて䤻型を作る简蝕解剖（コロジオ ンス・アナトミー）であつて，耳管軟骨，脳膜，その 他の軟部組織を具有する材料に就ての組織解剖学的研 究は極めて少い。

頭蓋内合併症又は迷路内外の炎症及び之によつて招 来せられる合併症の成立についての知見を弘めるに は，臨床及び剖見等と相俟つて，正常人に於ける側頭 骨そのま>の，特に迷路附近の組織学的解剖関係を鮮 明することが最も必要である，然るに，骨性迷路囊よ り深部に就いて，特にその隣接部骨並びに軟部組織を つけた全側頭骨の連続組織切片による系統的観察は未 だ行われていない。

こ〉に於いて私は，中，内耳壁及びその周囲，特に 中耳腔並びに骨性迷路覆より岩様骨尖端に至る含気蜂 巣の状態，含気腔の表面を被える被覆組織，側頭骨と 頭蓋腔との関係を組織解剖学的に検索した.

\section{研究材料取び研究方法}

研究材料は新大解剖学教室, 工藤教授並びに平沢助 教授の御好意により，同教室より割愛された。年令18 才より 77 才，男性 22 例，女性 8 例の総数 30 例，56個の 側頭骨である。

\section{研究方法}

側頭骨を周囲の隣接部即ち蝶形骨，及び後頭骨の一 部，脳膜，耳管軟骨，結合織，筋肉等を附けたまま離 断し，固定，脱灰，ツェロイジン包埋を行い，錐体上 縁に或は垂直に或は平行に20 40 $\mu$ ，の約700万至 1500 枚の連続切片を作り，染色検索した。

\section{成 綪}

1. 鼓室上壁に於ける含気蜂巣の発育状態, 発育強度なるもの……...................21\% 中等度なるもの……...................25\% 弱度なるもの………....................11\% 発育を欠如するもの…………........43\%

2. 鼓室下壁に於ける含気蜂巣の発育状態 蜂巣の
発育なきもの $43 \%$ 発育中等度のもの $29 \%$ ，発育強度 なものと，発育弱度なものは遥加に少くて，17\%，と 11\%，である.

\section{3. 省略}

4. 鼓室下壁における含気蜂巣の発育可良なもので は，鼓室底より上方に向つて多数の細長い骨柱様隆起 が突出している，之に反し，その発育を欠如するもの では鼓室底が平坦である。

5. 鼓室前壁に於ては，含気蜂巣の欠如するものが $50 \%$ ，発育中等度のもの $32 \%$ ，発育強度なものと弱 度なものは遥かに少く $7 \%$ と $11 \%$ にずない.

6. 耳管峰巣の発育状態。蜂巣の発育なきもの $52 \%$ 中等度なるもの $30 \% ，$ 弱度なもの $11 \% ，$ 強度なものは 僅かに $7 \%$ にずない.

7. 骨性迷路䛓並びに内耳道骨壁の上方に於ては， 含気蜂巣の欠如するもの $47 \%$ ，中等度のもの $28 \% ，$ 強 度なものと弱度なものは各々僅かに $14 \%$ ある。

8. 骨性迷路囊の後方で，之と錐体後壁との間に於 ける蜂巣の発育状態。発育なきもの $50 \%$ ，中等度のも の $33 \%$ ，強度なもの $11 \% ，$ 弱度なもの $7 \%$ ある。

9. 骨性迷路露の下方に於いては，蜂巣の発育なき もの $53 \%$ ，発育中等度なもの $29 \% ，$ 強度なもの $11 \%$ ， 弱度なもの $7 \%$ \%゙る。

10. 錐体尖端部に於ける蜂巣の発育状態，発育なき もの $38 \% ，$ 発育中等度なもの $32 \% ，$ 弱度なもの $16 \%$ ， 強度なものは僅かに14\%である。

11. 錐体尖端部に於ける含気機転は如何なる道を通 つて行われるか. 完成せる蜂巣, 含気機転の進行が中 絶或は停止せる諸々の例より綜合して，次の 3 途を考 える事が出来る。

a. 後外方なる乳様乫起部の蜂巣が深部に向つて 伸び内耳道の上を通過して，前内方の錐体尖端に至る もの.

b. 耳管の鼓室開口部附近に発育せる蜂巣一（耳 管周囲蜂巣) 一が伸びて，内頸動脈管滕部の内下方に 至り，水平内頸動脈管に沿うて，その後方及び下方に 進行するもの.

c. 蝸牛殼骨壁の内頸動脈管に接する部位の下方 即ち鼓室底或は蝸牛殼下方より䁰動脈管水平部に沿う てその下方に至るもの.

12. 乳様部に於ける含気蜂巣の発育状態. 発育中等 度のもの $32 \%$, 弱度なもの $30 \%$, 強度なものと全然欠 如するものは18\%と20\%である。

13. 乳様突起に於いて蜂巣の発育が甚だ良いもので 
はアアントルムの骨壁並びにその下壁から洞内に向つ て多数の細長い骨杜様隆起が笑出しており，之に反し て前者の発育が甚だ不良なものでは，アントルムの壁 は平滑である。

14. 鼓室に於ける蜂巣発育の可良なものでは, 錐尖 部及び乳様部等に於ける蜂巣の発育もまた可良であ る，反対に，鼓室に於いてその発育を欠くものでは錐 体尖端部及び乳様部に於いてもまた相似た所見を呈す る.けれども錐体尖端部は乳様部に比して蜂巣発育の 悪いものが多い.

一般的には，全側頭骨の各部位に於ける蜂巣発育の 状態は，ほs゙平行しているものが多いと云う事が出来 る.

15. 上記各部の蜂巣発育を比較すると, 左右側別差 異は認めないが，性別関係では，男性は発育の強度並 びに中等度のものの総てを占めておるのに，女性では 全然これの欠如するものが多い.

\section{下田の第 2 編}

「側頭骨含気蜂巣の被覆組織及び被覆組織と含気蜂 巣発育状態との関係について」と云うので非常に興味 のある論交だが，こ〉には省略する。

\section{第 3 篇 側頭骨錐体尖端部の微細構造殊に錐体尖} 端部に於ける骨間隐に就いて

日耳鼻 39. 12. (昭8. 12)

此処で錐体尖端部と呼んでいるのは，骨部耳管開口 部, 鼓室前壁, 蝸牛殼及び内耳道の前壁より内方に位 置する部分の錐体骨である. 錐体前面, 錐体後面, 及 び下面を形成する骨質を便宜上各々前壁, 後壁, 下壁 と呼ぶ。

\section{総 括}

錐体尖端部の蜂巣の発育状況, 尖端部隔壁, 水平部 内頸動脈管壁等における骨間吵或は骨欠損等について の組織的検査で，次の様な成績を得た。

1）-30例中24例の多数に於て，錐尖部の何れかの部 分に異常と認むべき先天的間陌の存在を見た。

2）か つる骨間隚が多数に存するのは

(1) 錐体前壁，就中，三叉神経圧痕部

(2) 耳管と内頸動脈管水平部との間

(3) 水平部内頸動脈管に単独に見るもの

(4) 錐体下壁（底）

(5) 錐体後壁

(6) 鼓室緊張筋管

(7) 耳管に単独に見るもの

の順序で，就中，前 5 者に見たものが甚だ多い.
3）錐体前骨壁に於て間隚の存在するのは, 三又神経の圧痕部におけるもの，22例 (73.3\%) その他の領域におけるもの， 両者同時に存するもの， 16例 $(53.3 \%)$ 16例である。 即ち三又神経圧痕部におけるものが最も多数である. 間吵の数は各例に於て $1 \sim 5$ 個である.而して之等の 間趂を充たせるものは附近の脳硬膜の骨膜 組 織であ り，多くは錐体内に存する骨髄質に直結し，殆んど常 に両者を結ぶ血管を入れている。

4）耳管と内頸動脈管水平部との間に於て，両者の 骨壁に間吵を有するもの 20例 $(66.6 \%)$ で，間嘹の数 は各例に於て $1 \sim 2$ 個である.

か>る間隚の位置は, 大多数に於て, 耳管の骨軟骨 移行部である。この間吵を充す結合織は内頸動脈の外 膜と耳管上皮下組織又は耳管軟骨部の周囲組織とに連 なり，殆んど常に両者を結ぶ幾つかの血管を入れてい、 る.

5）内頸動脈管水平部に単独に見られたものは，16 例 $(53.3 \%)$ で，各例に於て $1 \sim 4$ 個を算し，その場 所は一定せず，かっる間嘹によつて内頸動脈外膜は結 合織を介して周囲に存する骨髄質と連絡せられ，殆ん ぞ常に血管を入れている。

6）錐体の下壁に於いて間陵を見たのは13例（43.3 \%)で，その総てが錐体尖端に近い岩様，後頭骨裂孔 附近にあり，且つその 2 例を除く11例に於いては，何 れも種々の細長い管状をなして錐体内に突入し，その 数は各例に於いて $1 \sim 4$ 個を算した。楔状後頭骨裂孔 内を充せる結合織は血管を含み，之等の間隙中に入り 込み，その血管は内部の髄質中に走る;

7）錐体後壁に於いて間吵を見たもの，8例（26.7 \%)で，うち，尖端にあるもの 4 例，前半にあるもの 1 例，中央部にあるもの 2 例，前及び後半部に各 1 個 あるもの 1 例であつた，之れを充たせる組織は前壁に 於けると相同じ.

8）鼓膜張筋管に間隙を見たもの 2 例，うち 1 例は 同時に耳管及び内頸動脈管にも之をもつていた。

9）耳管骨部に単独に見られたのは 1 例のみ,

10）以上述べた異常な骨間隚の存在は，錐体内部に おける含気機転と密接な関係を有のものの様である. 即ちこれら屍体のらち含気蜂巣の全然欠如せるものは 1 例，弱度の含気機転を示せるもの11例，中等度及び 高度の含気機転を見たのは僅かに 2 及び 3 例の合計 5 例にすぎず，而も中等度以上の含気蜂巣発育を示せる ものは，単に 1 力所に間陵を有するにすぎず，且つ之 
は一般に最も多い三叉神経圧痕部に於いてであつて， 唯 2 例のみが耳管, 内頸動脈管にあつた.

11）含気㙨転の良好な例で間隚を有するものは，常 にその場所に限局せる含気抑制部の存するを見た．即 ち 5 例に於いては，錐体の中央部は発育良好なる含気 蜂巣を見るが，耳管骨軟骨移行部と内頸動脈管との 間，三叉神経圧痕部附近又は錐体の尖端部等に於いて は, 少しばかりの限局せる骨髄巣を有し，その部に相 当する、骨に間隙が存した。

12）従つて上述の如き異常な骨間隙は錐体内含気機 転の不良なる骨，或は一般に含気機転の良いものと雖 も，何れか限局的に含気機転の抑制のある骨部に生成 せられると云う事が出来る.

13）吾々が従来，金城鉄壁と思つていた岩様骨錐体 尖端部にも，実にかくの如く多数の骨欠損 部が有つ て，頭笽整と直接或は関接に交通し，而吕も，その中 には，毎常大小種々の血管を入れている事実は，臨床 上，吾々の注意を喚起するに足る必のがある. 就中， 錐体前壁の三叉神経節圧痕部，錐体底面の尖端に近く 楔状後頭骨裂孔附近は特に注目に值する。かつる事実 は, 従来, 吾乃が理解に苦しんだ長期炎症時に於ける 神経症状, 或は頭蓋内合併症の如きもの>説明を, 䓕 だ容易にしたといえるであろう。

\section{人体聴器の内淋巴管及び内淋巴蹪に関する研究}

北村雄次郎 新潟医会誌 63.6. (昭 24.6)

内リンパ管及び内リンパ襄に関する研究はまだ充分 でない。

可究讨料 聴器に变化のない日本火屋の岩様骨，男 13. 女12. 計25例について行つた。

\section{成 績}

1）内リンパ管は前庭導水管内を走る膜様迷路の一 部であつて，その導水管は迷治殼の連続である.

内リンパ管は前庭内に於いて棈円鸾と球状囊とを凡 そ斜めV字型に連絡する. 副管の前庭導水管静脈々並 んで，上・後半規管の連合脚の後上外方より後外上方 に軽度の彎曲を画きつ〉，不正三角ないし漏斗状の扁 平な管となつて，導水管内を走り，内耳道の側壁と $\mathrm{S}$ 状洞溝の略中央部を更に下方に走つて迷路殼を貫通 し，遂に岩様骨後面なる開口部，即ち前庭導水管外口 に達する。

2）内リンパ雯は錐体後面の外表1/3地域にある，ほ ぐ逆直角三角形の圧痕部（内リンパ小窩）に占位し， 内外二葉の硬脳膜に包まれ，ビルネ形を呈せる小指頭 大の扁平な盲裂で，その内側はＳ状洞の壁に接する.
3）内リンパ管は，長さ $6 \mathrm{~mm}$ ， 中，長径 $4 \mathrm{~mm}$; 短径 $0.15 \mathrm{~mm}$ で, 内リンパ露は, 長さ $13 \mathrm{~mm}$, 巾, 長径 $6.5 \mathrm{~mm}$, 短径 $0.5 \mathrm{~mm}$ である.

4）内腔は空虚であるが，時に退行变性産物を入れ ておるものがある.

5）同管及び囊の固有壁は上皮，上皮下層（基礎膜 を欠く)より成り，上皮の直下に直接上皮下結合織層 が続く.

6）上皮下層は内リンパ管に於ては，箖疎な結合織 並に導水管に密に結合する骨膜様の緻密な結合織の内 外 2 層，内リンパ霊に於いては，上皮におけると同じ く内淋巴管の上皮下組織の連続で，緻密，蒜疎の両層 が縦走の線維を増し, 漸次一つの薄層となつて脳硬膜 に移行する。

7）内リンパ管には壁及び絨毛，娘腔形成がありそ の周囲に見られる䇗柾結合織層は粗網傍を含み，特別 に毛細血管の分布，組織球性細胞，脂肪細胞等に富ん でいる.

8）動脈，前庭導水管内孔に於いて球状 霬より一 枝, 半規言並びに棈円覆より一つの枝を受け, 内淋巴 管に平行に走る。前逳導水管静脈は，中間部に於て叉 状に分枝し，一方は内リンパ管の中央上皮下層より管 壁に入り，更に前庭導水管外孔を経て，内リンパ靁の 内壁，上皮下層へ分布する，他方は内淋巴管周囲の八 ーベルス管に合して直接 $\mathrm{S}$ 状洞に交通するか或はハー ペルス管と共に内リンパ霊の上皮下層に入り，後者の 静脈と合流して $\mathrm{S}$ 状洞へ流入する。

9）楕円霊管と球状囊管とは前㝢内に於いて互にV 字型ないし直角に連絡し，共同管なる連合内リンパ管 となる。

10）楕円囊管と球状囊管とは前庭内に於て互にV字 型乃至は直角に連結し，共同管である連合内淋巴管 （前庭内）となり，更に内淋巴管（前庭導水管内）に 接続する.

11）更に腸管弁と相似た機能を有し，之等内リンパ 管系の一種特有な存在とも云うべき，楕円震内リンパ 管弁は楕円霆と，棈円囊管との移行部にある膜様の㦼 譬である。

12）一種の骨性内リンパ管とも見做される前莛導水 管は迷路殼の各骨層を貫通する。

13）内リンパ管内外の両壁は，前庭導水管の中間部 又は末端部に於いて，脳腔なしいS 状洞に開放泩に接 触するもの，又含気蜂巣の発育が㣽だ可良なるもので は，迷路の下の蜂栄に介在する。 


\section{以上を要約すると}

内淋巴管は，卵形衰管と楕円囊管との連合管で内孔 を作り，間もなく急に太くなり，いつしか内淋巴囊に 移行する，全長 $2 \mathrm{~cm}$ 足らず，管の太い部分と囊との境 界は不明膫であるが，脳硬膜で包まれた部分を囊と見 れば可い。管には 3 個所の狭窄部があり，その間に拡

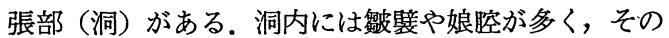
周辺はあらい結合織に富む。衰は内耳道口の後上にあ る骨窩に居を占め略々小指頭大である。

\section{邦人の蝸牛亮導水管の形態計測並びに組織学的}

\section{研究}

広谷常治 新潟医会誌 63.8 (昭24.8)

年令を異にする邦人の屍 4 例につき象形複製模型を 作つて，その形態を，同じく18例について顕微計測を 行い，第 3 に組織像を調べた。

概略を記載すると次の通り。

外リンパ管は蝸牛の起始部にその内孔をもち, 内耳 道口の下部にある外孔を以て, 後頭蓋腔の脳軟膜腔に 開いている長さ $1 \mathrm{~cm}$ 余の細管である.内孔に近く狭部 がある.そののち極めて徐々に太さを増し，遂に円形 乃至三角形の広い外孔を以て終る. 陕部の内貯は網状 内皮組織様のもので充たされている。

\section{成 績}

\section{1. 象形複製模型による形態}

胎览に於いては，外管の内孔は正円空の前の部分に あり，外孔は蜘蛛膜下腔と舌咽神経管に開孔し，小児 並びに成人と同じである.

2 才のものの断面を見ると半円形で，初め，頭蓋下 に，次いで舌咽神経管に開口している.

\section{2. 計測値}

全長は 2 才で $8 \mathrm{~mm} .10$ 才で12 13m. 内孔の内径は 0.34 0.86mmである.内孔から陕部までの距離は個人差 が相当ある. 即ち $0.5 \mathrm{~mm}$ から 30 才以後では $10 \mathrm{~mm}$ むる.

峡部の内径は0.02 $0.41 \mathrm{~mm}$, 外孔の内径は0.68 $3.5 \mathrm{~mm}$ である。

\section{3. 組織的所見}

胎児に於ては管の全長に亘り内外 2 層の結合織膜を 見るが，内層は蜘蛛膜，外層は脳硬膜の延長である. 内腔は胎児では全管を通じて空虚である，蝸牛殼静脈 は導水管の前部から出て，約 $1 \mathrm{~mm}$ の距離を距ててほほ 之と平行に走つている.

次に高原高三教授の教室でその指導の下に行われた 本症に関係のある基礎的研究を抄録少る。

錐体尖炎による頭蓋内合併症の発現経路に関する

\section{基礎的研究}

森田修代 耳鼻臨，44. 9. (昭26.9)

（鳥居教授還歷記念論文）

その二，錐体部の骨表面に於ける骨小孔の計測.

私は錐体と硬脳膜をつなぐ細小血管及び結合織が出 入する骨小孔を肉眼的に計測して，どの部位にどの位 の数が存在するかを調査した。

調查材料 日本人唒骨，89体．うち女性52体，男性 32体，結果から見て，それらを下記の如く細分し記載 する。

錐体の壁を脳面と底面とに分け，前者を大脳面と小 脳面に分け，その大脳面の中に

1. 三叉神経圧痕部

2. それ以外の大脳面

3. 棘孔周囲

4. 岩鱗縫合部

小脳面の方は

5. 球形下窩及び周囲

6. それ以外の小艏面

錐体底面の方は

7. 錐体骨尖端部の底面

8. 内頸動脈管外孔部の周囲.

参考として乳様部

9. アントルム

10. 茎乳孔周囲

11. 外耳道底面

\section{検查成績}

一般的に見れば，錐体底面に最も多く，乳様部之に 次ぎ，錐体脳面が最低位である．脳面では大脳面が小 脸面よりも遙に多い. 左右では余り差がない. 平均值 を見ると，

$\begin{array}{lr}\text { 錐体脳面のうち } & \\ \text { 太脳面の平均 } & 16.1 \text { 個 } \\ \text { 小脳面の平均 } & 5.7 \text { 個 } \\ \text { 錐体底面 } & 44.8 \text { 個 } \\ \text { 乳 様 部 } & 38.3 \text { 個 }\end{array}$

\section{考 案}

側頭骨表面の骨小孔は，之に接する軟組織との間に 血管ないし神経を交連するものであり，且つ之等血管 や神経の周囲には，結合織が存在する，一般に炎症は 主として先ず血管や結合織等を伝つて進展波及するも のであるから，骨小孔は側頭骨内の炎症が接触せる軟 組織に移行する際の重要な指標となるものである．錐 体部のうち，脳面の骨小孔を見るに，錐体底面及び乳 様部に比べると少数とは云え，案外多数の骨小孔が存 
在する，脳硬膜炎は，髄膜炎，脳膿瘍，洞血栓等に比 し，それ自体による生命の危険がなく，臨床症状も軽 くて，頭重感，頭痛，微熱，便通異常等を伴うに過ぎ ないために，余り注目されていないが，その頻度は極 めて大きく，且つ生命をおびやかす頭蓋内合併症の前 期疾患であり，凡ゆる頭蓋内合併症の根底をなすもの である．だから骨小孔は頭蓋内合併症発現の基幹をな すものと云える.

錐体脳面における分布を見るに，大脳面に於いて小 脳面より遥かに多い事実は，大脳面から発展する頭蓋 内合併症が，小脳面のそれよりも遥に頻度の多い臨床 的事実とよく符合する. 又大脳面の中. 三文神経圧痕 部附近に最も多い点は，下田（1933年）等の成績と一 致し，錐体尖咨症状として三又神経障碍症状の頻度が 最も大きい臨床的事実とも良く符合する．錐体小脳面 では球形下窩及びその周囲以外には殆んぞ骨小孔を認 めない．料孔附近にも少数ながら存在するがその数並 びに大さには可成りの個人差がある。

\section{其の3. 脳硬膜外腔の研究}

\section{附 脳硬膜の抵抗減弱部}

墨汁を脳硬膜に注入してその拡散する状況を肉眼的 並びに組織学的に調査した。

検查材料並びに方法

成人屍体 12 体，屁胎児（5〜8 分月） 5 体を用いた。 開頭し脳髄を摘除して, 脳硬膜をつけたま〉の頭蓋 底を露呈し，錐体大脳面，及び小脳面の硬膜外腟に墨 汁を注入する. 注入された墨汁の拡散状況を，硬膜を 透視して内被面から肉眼的に筧察したのち，型の如く 処理して組織学的に検鏡した。

成 績

墨汁の搪散状況（肉眼的所見）

小点状拡散.この種の拡散は雓体大脳面に見られ る. 墨㳆注入量がや>多量であつたり，加圧がや > 強 かつたりすると此の小黒点部では,'脳硬膜組織が破れ て，墨汁は表面に流出する，此の小黒点部は後述する 脳硬膜の抵抗減弱部である。

樹枝状拡散, ·之は硬膜の細小血管の周囲に添う樹枝 状及至細線状に拡散する形である。

濡慢性拡散. 之は 5 力月の胎児にのみ見られた。 逆流。墨汁は硬膜外腔に拡散せず，刺入孔から逆流 してしまうもので，之は錐体小脳面に見られる。 脳硬膜抵抗減弱部に就いて。 小点状拡散の小黒点は屢々容易に破れるので，明ら かに抵抗減弱部と思われる。それがどんな部位である
かを見るに，肉眼的に見て，硬膜小孔と仮称してよい 様な部位である事を知つた。即ち，内被面から見る と，周間の乳白色不透明な部に比べて，半透明に見え る小点がある.かような半透明点状部の生ずる所以は, 内被層下の強勒な結合織線維束が縦横に交錯する場合

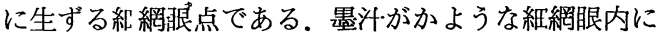
特に多量にたまる事は当然であり，圧又は量が大きく なれば，容易にそこの薄い内被層を破つて表面に流出 するのである。かかる硬膜小孔の分布状況を見るに， 専ら大脳面に多々，梀孔周囲，三更神経圧痕部，球形 隆起前方などに多数認められるが，小脳面には極めて 少く，唯，内耳道前方に少しばかり見られる。

\section{組織学的所見}

墨斗は，所在の骨小孔は勿論，遠く骨䯚腔，蜂巣及 びハーベルス管内にまで進入し，錐体全域に及んでい る。骨髄内では主として血管周堜に，一部その辺縁部 にも見られる。蜂巣では主に毛細血管の周囲に見られ る。

\section{考 案}

私が錐体部に接する脳硬獏に一定の抵抗減弱部を見 出したのは注目に值するものと思う。而して之が錐体 大脳面に多く，小脳面に少い事実は，骨小孔も錐体大 脳面に多い事実と相诶つて，錐体炎から起る頭蓋内合 併症が大脳面から発現するものの多い臨床的事実を説 明する新らしい一根拠を提供するものと考える.

\section{脳脊髄液関係の基礎的研究}

岩手医大の金野教授㚙その門下生と共に種々の研究 をしているが，個々の抄録をする前に，金野教授が昭

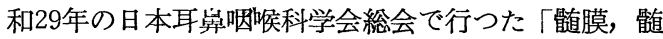
液の諸問題」と云う宿題報告の中に，全体の事が述べ られているので，その中から主な部分を拾つて見たい と思う。

その中で金野教授は䯑運液は何処で作られるか，何処 で吸収されるか，髄液には流れがあるか，䯣液とはど んなものか，どう云う作用を持つているか，に就いて 報告している。

以上の事については命日まで多数の報告があるが， K. Key Retzius に始まり Weed に至る一連の研究 から得られた総論は，髄夜は脳の脈絡層から分泌せら れ，一部は Magendie 孔及び Ruschka 孔を通つて 脳軟膜腔に入り，その一部は脳底槽に出で，Sylvius 脳裂から大脳半球の突面に，一部は大槽を通つて背䯣 軟膜腔に出で，背髄の後側を流北て，背髄下部に至 り，その腹側を通つて上方に登り，何れも Pacchion 
顆粒によつて上矢状静脈洞に吸収されると云う。

中 略

いろいろな実験を行つた成績を基として考えると， 髄液が脈絡層から分泌されると云う事は承認できる が，その量は私共が考えていたよりも少なく，之のみ がリコールの源泉だとは断定できないのである。

然らば，リコールの生成は脈絡層以外の何所で行わ れるものであろうか. 之について色々の実験を行つた 結果, リコールは軟膜膑の何処からでも生産されると 云う事が判つた。

\section{血液葡液関門に就いての考察}

従来これは，血液鹃夜関門と云つているが，最近， Bromann は此の名称は不適当で，髄膜血管の選択的 透過性と呼ぶべきであろうと云つている。加るる装置 の生物学的意義を考えると，恐らく，䯋腔を防護する 妙器だろうと考えられるが，その本態は末だ明らかに されていない，私は，血管壁の構造，滲透圧，コロイ ド參透圧，膜平衡及び神経支配等による，モザイック 現象だと考え度いのである。

\section{剈逜膜の透過性に関する実験的研究}

塩谷 裕 日耳鼻, 52.6. (昭24.6)

リコールが何所で吸収されるかと云う問題. 色々研 究した結果, 脳及び脊髄の細静脈は勿論, 大静脈及び 上矢状洞の血管壁からも直接血行に吸収される事, 脳 神経, 殊に嗅神経周囲, 及び春髄神経の周 园を通つ て，吸収される事が確認された。

\section{剈遖液の吸収路に関する実験的研究}

後藤夫幸 日耳鼻 59.7.（昭31.7）

リコールに流れがあるか。

同位元素 $\mathrm{P}^{32}$ による実験

リコールの還流について従来行われている研究方法 は，色素による実験であるが，少量のリコール採取に よつても著しい移動がある事を見たので同位元素 $\mathrm{P} 32$ による実験を行うた，大を用い，髄夜腔の各部に $\mathrm{P}^{32}$ を注入し，その移動をガイガー，ミュラーの計測管を 用いて追跡した。 その結論では，リコールには自主的 な還流はないか，或はあつても極めて軽微なものであ つて，殆んど流れとして考える事の出来ない程度であ る。

\section{䯣液の還流に関する実験的研究}

伊藤 卓 日耳鼻 58.9. (昭30.9)

脳标”㩆液糖量の変化に関する研究

第 3 編 脳脊葡液の吸収並びに圧力に関する研究

一条泰一 新潟医会誌 63.1. (昭24.1)

$3-24$

\section{結 論}

1. 健康家鬼の蜘蛛膜下腔にウラニンを注入すると 尿中へは.7〜13分（平均9.5分）で現われるが, 化膿性 脳膜炎家児ではその排泄が非常に遅くなる。そ程度 は病症の程度に大体平行する。

2. 健康時でも, 䋞膜炎時でもリコールの採取量と リコール圧の下降とは，直線的関係にあるが，胹膜炎 時には健康時に比して，著しく多量の液が 採取でき る.

3. 液圧が零になるまで髄夜を採つたのち，その圧 の恢復状沉を見ると，単指数函数式で現わされるが， 脳膜炎では健康時に比して著しく急な上昇曲線を画 く：之等の成績から，脳膜炎時にはリコールの生成が 増加しているのに; その吸收が障害されている。 その ために; リコールが脊髄腔内に禁積貯溜した状態にな つているのである.

\section{鹃液の穿訽筽係についての究 化膿性脳膜炎の診断及び治療に関する研究の二 腰椎穿刺の価值に関する研究}

前編 臨床的観察

続編 細脊韍液反覆採取に就いての実験的研究 前田謙次郎 日耳鼻 37. $2 \sim 3 .($ 昭 6. 5, 6)

\section{緒言の一部}

化膿性脳軟膜炎が腰椎穿刺のみによつて完全に治痹 する事は，吾々も稀に経験している，而しかかる腰椎 穿刺の治癒传転に就いては，末だ明らかにされていな い. 或人は之を異常脳圧の下降，炎性産物の排出，脳 脊䯣液の新生並びに抗体産生の促進等に䚻している。 又, 脳脊䚛膜の諸薬剂に対する透過性を高める為だと 云う者もある。

然し脳圧の下降と云つても，ただ一過性のもの，炎 性産物の排出と云つても, 従来の採取量は極めて少量 であるから，そのような仮想に，果してどれ程の価値

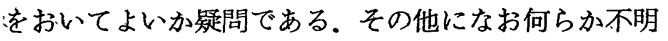
な因子があるように考えられる。それに関連して私共 は福島の「䁏椎穿刺後の血液中には一過性の白球增加 現象恓ある」と云う報告に着目した。私と渡辺(悌二) は此の報告に大きな興味を感じ，之を追試し，更に吾 が領域の疾患についての影響を極め，進んで穿刺施行 に際し留意すべき諸種の条件を検索し，又，臨床に於

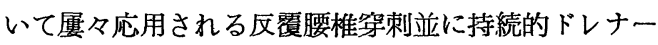
シ等と血液の変化像とを照合して，之に適切な間隔， その他を決定し，此の方面に於ける知見を弘めようと 企てた。 
以上の目的を以て本研究は，正常人立びに耳性㣻は 鼻性諸疾患の経過中に，頭蓋内合併症を起した症例に 就いて行つた。 そして各種要約の精密な検査は，後編 の動物実験に於いてした。

\section{結 論}

1. 正常脳膜を有する症例に，連日 1 ～ 5 日に亘る 腰椎穿刺を行つたものでは，大多数例に於て，第 1 な いし第 2 次穿刺で最高の白血球増加を招来する．その 後は回を重ねるに従つてその度を減じ，遂には変化を 見ないか，反つて減少を来す様になる。

2. 白血球増加の持続時間. 白血球増加の度に比例 し，第 1 〜第 2 日おいて最も長く，そののち漸次その 時間を短縮する。

3. 中性多核白血球は百分率，絶対数とも白血球総 数の変化とほ浪その規を一にする．即ち主として白血 球総数の变化を左右し，リンパ球はこれに反する。 そ の他の種類の白血球には，一定した変化を認めない. 病的白血球の出ることもあるが，重大な意義を認め難 w.

4. 上述の事実から，連日腰椎穿刺の治療的価値を 見ると，良好な影響を期待し得るのは 2 日連続を限度 とする様である。

5. 而して前編の正常人並びに䋞膜炎例の結果から 考えると，本成績は脑膜炎時においても，ほぼ同様な 事が推定し得られる。

6. 正常の脳膜を持つものに毎日反覆して腰椎第刺 を行うと，漸次にその採取が困難になる傾向を認め る。

以上の実験が行われた正常人は10名，非合併内耳炎 は 7 例，横洞周囲膿疸は 5 例，脑膜炎 9 例，脳膿瘍方 6 例である。

\section{その二 脳脊能液の反覆採取についての実験的観 察 (家鬼)}

結論.

1. 家鬼の小脳延髄哓を穿刺し； ある量のリコール を採取すると，その後間もなく白血球の増多を来た し， $2 \sim 3$ 時間でその最高値に達し， 5 〜 時間の持 続を経て，漸次旧に復する。

2. その際，採取液量の多いものほど, 白血球の増 加が高度で，その持続時間も長い。

3. 連日これを反覆すると，3〜4 日で最高度の増 加及び最長の持続を示し，のち淵次その度を減少す る. 而してこの連日穿刺による白血球増加の度は, '他 の穿刺試験例に比して最も高い。これを正常人に於て
した成績に比較すると，只，最高度を示す日時に於て 異るのみで，その持続日数はほほほ相似ている.

4. 上述の連日穿刺を， $2 \sim 3$ 日の間隔をおいて試 みると，その最高増加度は常に第一回連日穿刺時にあ り、回を重ねるに従つて漸次その度を減じ，第 3 週期に 至ると，遂に全身症状に著明な变化が起る。

5. 次に隔日又は 2 日間隔で突刺採取を反覆すると 連日穿刺のものに相似て回を重ねるに従い，白血球増 加の程度並びにその持続時間は，いよいよ高く且つ長 くなるが，第 3 〜第 4 回が限度であつて，その後は， その反応の減弱して来る者が多い.

6. 上述の事実から，リコール採取によつて，白血 球増多症を惹起し得るのは，連日穿刺にあつては，ほ ほ 3〜4 日, 隔日穿刺においては 7〜8 回, 2 日毎の 穿刺にあつては10～12日に亘ると見做す事が出来る. 従つて，之が脳膜炎の治療的俯用に際し，長期に亘る 連用を必要とする場合には，特別の場合を除き，之を 連日施行するよりも，隔日ないし毎 2 日の如き，短い 間隔をおいて反覆する事によつて，長い効果を期待す る事が出来る.

7. かくの如く，連続穿刺にあつて，何れも一定の 回次を限度として白血球増加度が減じ来る所以は, 限 度を越えた穿刺採取による全身障碍に起因すると見て ほほ俱りがないであろう。

8. 仮性エオジン好細胞は百分率，絶対数共に白血 球総数の増減と一致し, リンパ球は之と相反するのが 通例である。

9. 他種の白血球には，特に一定せる変化は認め難 w.

10. 家鬼においては，連日 $1 \mathrm{cc}$ リコール採取を反 覆しても，多数例において何等困難を感じない. 但 し，間歇的連日穿刺に扔いて,これが 3 週日に及べ ば，時にそれが困難となるのみならず，漸次，顕著な 全身障碍を起すものが多い.

渡辺悌二

家鬼に可及的大量穿剌を行つた後の，血液の変化

この実験では，前田の少量穿刺実験に比べて，一般 に白血球増加の度が高く, その変化もょり明膫であ る.

成 績

1. 連日穿刺を行つたもの

第 2 日の穿刺後に，白血球の増加が最も高度で，そ の持続時間も長く, 実に24時間に亘つて益々強く, 第 3 日の直後に於てその最高值を示す. 然し，第 3 , 第 4 
日となると，漸次その度を減少する。

2. 隔日穿刺を行つたもの

第 1 , 第 3 , 第 5 , 第 7 日 そ漸次その増加度を高めるが, その持続時間は第 3 日に最も長い. 第 9 日よりはその 反応が漸次減少して行く. 即ち穿刺回数より云えば; 第2,第3,第 4 回において，その反応が最も強い.

3. 毎 2 日に穿刺を行つたもの

これもほほ前者と相似た成績で，第 5 回穿刺（第 13 回）後よりは反応微弱となり，漸次その度を減ずる。

4. 後頭下腔において持続的排泄を行つたもの

これでは第 1 , 第 2 , 第 3 日と漸次白血球の増加を高 め，第 4 日において最高に達し，以後，急激にその度 を減じ，その後，多少の動摇を示しつつ衝次減少して 行く. 此の変化はほほほ連日穿刺のものに似ているが， その白血球増加の度は，前者においては僅かに 3,000 に過ぎないのに，後者においては19,000に及んだ。

以上，前田及び渡辺の得た成績から，次の事が云え るであろう。

1. 腰椎第刺はこれが一つの有力な刺㦸となつて， 人体および動物の全身血に顕著な白血球増加をおこ す.

2. その白血球増加は, 穿刺後 $1 \sim 5$ 時間に於て最 高に達する。

3.これを反覆施行すると，一程度迄は穿刺を重ね るに従つて，增多の程度およびその持続時間を增す。 その多くは人間に於ては第 1 回, 動物においては第 2 第 3 および第 4 回穿刺を以て最高値を示し，以後，比 較的急に減少を来すものの様である，その関係は隔日 穿刺のもの，及び毎 2 日穿刺のものでも，やや相似て いる. 但し後者に於ては白血球增加の度が著しく高く 且つ長い.

4. 持続的な排泄に於ては, 白血球増多の程度が最 も高いが，その持続時間は，ほ汪 4 日間であつて，そ れ以後に於ては大なる增加を期待し得ない。

従つて腰椎穿刺によつて脳膜炎に好影響を与えるも のは，上述の色々な仮説の他に全身血の白血球増加に よる病勢の減殺を首肯しうるであろう。

而して実際問題としては，連日腰椎穿刺を行うより も，隔日又は 2 日おきに行うことが，白血球増加を最 も強盛ならしめ, 且つその持続時間を延長せしめ得 る. 只, 持続的リコール排泄は, 血液像に対する影響 が甚だ高度だから，病勢を頓座せしめる上に多大の効 果があると見てよい，只，うらむらくは，その白血球 増加の持続時間は数日以上を望み得ない。

\section{化蹰性脳膜炎に関する研究}

腰推弓截除術によるリコールの持続的排泄が治癒 機転に及ぼす影響

深瀬亮作 日耳鼻 40.5（昭9.5）

はしがき。吾が領域に於ける化膿性脳膜炎の治療率 は近時著しく向上しつうある. その主たる要因は観血 的療法の進歩にありと云うを得へく，即ち，内耳摘出 脑橋槽の開放，反覆腰椎呀刺によるリコールの排除等 これである、腰椎穿刺の反覆施行によつて良好な結果 を見るもののある事実は，吾人をしてその持続的排泄 を企図せしめるに至つた。鳥居教授が昭和 5 年，腰椎 弓截除術を行つて腰椎管を開放し，之によつて治療せ しめ得た症例を報告し，翌年田中，小田教授の腰椎第 刺針恒置法による治験例の報告があつて以来，各方面 の大なる注意を喚起するに至つた，蓋し，脳底脳膜炎 そ雖も，“極めて早期に於て既に腰椎管液に変化を見る 臨床的経験と，脊椎管が脳脊咽夜全量の約半分を文れ ている事実，とを併世考えると，腰椎部に持続排泣孔 を設けるの有効なことが容易に考え得られるからであ る.

私は之炕関する実験的研究を行い，手術の時期と治 癒との関係，治瘑後における局所の組織的变化等に就 て一つの知見を得ようとした。

実験材料および実験方法

実験動物には大を使用し，黄色ブドー状球菌を後頭 下腔に注入し，第 5 腰椎弓の切除を行い，腰椎管を開 放した.

綜合的観察および考案

私は25䫓の大を用い，比敖的毒力の強い黄色ブドウ 状球菌を後頭下腔に注入し，一定時間ののち脊椎弓切 除を行い, リコールの持続的排泄をつけ，化膿性脳膜 炎の治癒に及汗す影響を見た。

対象動物は 5 頭．その一般状態をみると，菌液の蜘 蛛膜下腔注入後, ある潜伏期を経て, 脳膜の刺㦸症状 が現われ，次で麻瘦期に移行し，何れも2〜4日にし て死亡した。剖見の結果, 脳硬膜及び軟膜に高度の炎 症像を見た。

感染させたものに就て脊椎弓切除術施行迄の時間数 と治瘜との関係を見ると，12時間以内のものでは，9 例中 5 例の治癒を見, 他の 3 例に於ても生存日数の延 長を見た。就中, 感染直後に手術したものでは, 6 例 中 3 例の治瘾を見，他の 2 例に於ても著しい生存日数 の延長を見，然るに 24 時间〜48時間に手術したもので は，13例中，治瘺は僅に 3 例で，6例に著しい生存期間 
の延長を，他の 3 例に之に次ぐ好影響を見たに過ぎな い. 48時間後に手術を行つたものでは 3 例中 1 例が治 㾣し，他の 2 例は比較的早く死亡した。

以上の成績を通覧すれば，大体に於て，感染後手術 までの時間が短いものほど治癒率ま高く，就中，12時 間以内の手術例に於ては甚だ良好なる成績を見た。然 し48時間以上を経過しリコール所見の甚だ悪いものに 於ても，また該手術によつて治瘾し得たもののある事 実は，吾々の希望と努力とを最後の死戦期に至るまで 放杗すべきでない事を思わせる。

リコールの排泄日数と治瘜との関係

化膿性馏膜炎の治瘜の主なる因子は, リコールの充 分な排泄にある，と云えるが，持続的排泄を講ずるに 当つては，深く慎重でなければならない，急激に過ぐ れば虚脱を起す事が稀でないし，さればとて，その排 泄が遅すぎたり不充分であれば治療の目的を果す事が できない. 私の実験例に就いて見ても，リコールの排 泄が可良なために，予後を楽観していたもので突然死 亡した者がある。一般に脳硬膜を開放しても脳膜炎の 全治をまたずして閉鎖するか，或は少くとも排泄の不 良となることは私の経験したところである．本実験例 のうち最長のものでも 6 日を出でず，何等かの操作を 加えないものでは 2 日前後でリコールの排泄を見なく なるものが多い. 又症例によつては，手術時に既に， 予期した程の排泄を見ないものがある。そ排泄の不 良な原因としては 膿汁が濃厚であるとか，炎症産物 による傷の閉鎖, 瘾着, 対孔の欠除等をあげる事が出 来る. 生存日数の長い者ほぼ, リコールの排泄の日数 は長い. 感染後直ちに持続的排泄を行つた者ではリコ ールの排泄日数は短く, 概して $2 \sim 3$ 日である. 之は 恐らく，炎症の進行に先立つてリコールの排泄を企て たため，脳圧の交進を見ず，治痛の傾向が著しく増進 し，速かに創面の瘜着を来たすためであろう。

脊椎管開放の部位. 脊椎管を開放するために当つ て，その部位の選択は重要な意義を有つている，私の 症例で胸椎部開放したものは，4例共みな死亡し，術 後に於けるリコールの排泄が何れも悪かつた。 之は春 髄実質が管を充満していることによるので，腰椎下部 のように比較的空虚なものとは違う訳である.

\section{結 論}

1. 大の実験的黄色ブドウ状球菌性脳膜炎症例に， 脊椎弓切除術によるリコールの持続的排泄を企てたと ころ，全25例中 9 例の治瘾を見，12例に於ても良い影 響があつた。
2. その治瘺率は感染後，早期に手術を行つたもの ほぞ高く，殊に12時間以内に之を行つたものでは最も 良好である，但し48時間以上を経過したものでも，治 瘺したものがある。

3. その治癒率はリコールの排泄の長いものほど高 い，但し無処置に放置すれば，多くは 2 ～ 3 日で止 み，最長 6 日を越えたものはない.

\section{最近我が教空に於ける化膿性脳膜炎の治療法}

鳥居恵二 北越医会誌 49.8 (昭和6. 8)

中略。之を要するに, 耳性化膿性脳膜炎では, 色々 の意味から内耳手術を行う事によつて少なからず治瘜 率を高めうる。然らば内耳手術或は之と同時に脳橋槽 を開放する事によつて，大多数のものに治瘠を望み得 るかと云うと，遗憾ながら，確実性のない場合も少く ない，それは，内耳道を経由すると否とに拘らず，脳 橋槽からの排泄は短時日で停止する場合が多いからで ある。このような死亡例を剖見してみると，手術創附 近の炎性変化は既に去つて，正常なるか，或は結合織 性癒着を起して治瘜しているにも拘らず，健側部の脳 底に於てはなお高度の炎性変化を示し，それから大脳 山面に向つて拡大せる像を確かめ得たのである，之は 脳腔の複雑な構造に鑑み，常識的にも容易に首肯し得 るところである.

然りとすれば，かかる化膿性脳膜炎の治瘾を確実に せんとするには，ぞうすればよいかと云う事が問題に なる。

一体，脳脊髄腔と云う龙大な閉鎖腔に於て，而して その炎症が既に拡大せる時期に於て，之に只一個の排 泄孔を設けることに由て，その内容の完全な排泄を願 う事が無理なのである. 何処か適当な他の場所にもう 一個の対孔を作るべきだと云う事が考えられて来たの である。

では，その対孔を何処に造るべきか。まずその第一 は同一の直接感染地たる健康側の内耳附近であり，第 二は脊髓管である。

炎症がまだ脳底に主としてある場合，即ち初期の脳 底脸膜炎の時期であれば，健側の内耳道附近で足りる わけであるが, 健側の乳様突起を用いて,その内耳道附 近で脳腔を開放すると云う事は, 症例によつてはなか なか行い難い。例えば, 乳様突起の骨質が非常に硬く て，削開に相当の頭部振盪が予想せられる様なもので は，さなくとも拡大せんとする化膿性変化の進展を促 進させる結果となるから，之は絶対に避けねばならぬ し，また，場合によつては，そうでなくても，脳橋槽 
に達するため内耳の一部を犠性にせねばならぬ場合が ある，そうすると，両側の聴力を完全に失うと云う事 になつて，たとえ，脳膜炎功治瘾したとしても，救う べからざる禍根を将来に残す事になるから，之も出来 ない。

そういう理由から，健側内耳道附近に於て，脳腔を 開くと云う事は, 余程その可能性が限局せられて来る わけである。なお文献によれば,脳脊髄夜の全量は 120 ccで，その50\%が脊髄管内にあると云う.そうすると 炎症が既に脊髓腔系統に拡大しているものには脊髄管 内の内容物を排泄せしめる手段を講ずる事が甚だ重要 だと云わねばならぬ。

脊髄管のうち何処が可いかと云えば，後頭下腔若し くは腰椎腔以下の部分である.

そして之等二者の中, 後頭下腔は頭部の排膿には好 都合だけれぞも，脊髄管内の膿を誘導するには余りに 高位置にすぎるし，患者の多くは項強直や頭部後屈を 起しているから, 手術も後療法も困難だし, 附近にあ る重要な胸部を傷つける危険も考えられる.

そうすると腰部以下が最も安全であり，手術も容易 であると云う事になる。

かかる腰椎部以下の開放を化膿性脳膜炎に推奖した 記載は 2 〜あるが，その治療成績をあげたものは未 だ見当らない。

腰椎部に此の椂な排泄孔を設けるに当つても，或る 人は第 3 乃至第 4 腰椎を可とし, 或る人は仙骨部を推 奖している。

仙骨部にかかる排泄孔を設ける事は，脊髄管が比較 的浅い位置にある関係上，手術が比較的に楽な利点は あるが，排尿又は排便によつて創腔が汇染される危険 が多く, それよりも上部, 即ち第 3 〜第 4 腰椎附近で 行う事が安全である。

\section{中 略}

最後に脳腔切開創の後療法に就いて一言したい. 頭蓋腔は勿論, 腰椎管にあつても，その開放部に排 泄管（如何なる種類を問わず）或はタンポン等を挿入 することは絶対に避くべきだと云う事を私は強調す る. 脳膿瘍の後療法に於ても近年, 同様な傾向が強ま つている．之は脳実質の性状に鑑みて当然の事であ り，ゴム管又はガラス管を挿入すると，柔軟，脆弱な 脳質の軟化或は壊死等を招来し易く, 従つて资症を樑 部に向つて誘導し，或は拡大せしめる結果となる。神 経線維や神経幹は脳実質に比すれば，その抵抗に於て 幾分か勝つてはいようが，なお受傷性は大である、か
ら，排泄管を挿人する事は避けなければならぬ。脊髄 管にあつては臥位の選択さえよければリコールの排泄 は充分につき，時にはむしろ多きに過ぎる事されえあ る.従つて之は排泄管を挿入する事は無用であり，反 つて有害な場合が多い，次に腰椎管開放創では縫合を 行わず，全部哆開しておくのが可い，そうすれば後療 法が非常に楽であるし，何らかの理由で，切開線を上 方に延長する場合にも有利であるし，縫合を行わなく とも，リコールの排泄が止んで，経過が良好であれ ば，創腔は驚くほど短時間で狭少になり，閉鎖するの である。

腰椎管の位置は第 4 腰椎附近に於ては相当深く，人 によつては皮膚面より約 $10 \mathrm{~cm}$ を算する. 従つて腰椎弓 截除術を行い，之を開放せんとするには，皮切線の長 さは少くとも10cm以上である事が望ましい.

\section{化膿性脳膜炎の治療法について}

鳥居恵二 北越医会誌 53.12（昭13.11）

ここでは岡大の田中，小田教授の発表した所謂，第 刺針恒置法を紹介した後に次の事を補足しているる。

但し，田中法の不利な点としては，或は針の固定が ぞうもうまく行かず，或は濃いリコールでは流出が停 止し易い.それを円滑に流出させるための医師の努力 は相当大なるものがある．また此の方法では患者の安 静が絶対に必要であるが，それを望み得るもの性そう 多くはない.

そこで此の方法の用いられない場合には，私共の腰 椎管開放術が良い。此の腰椎管開放術も，慣れると比 較的短時間で出来るし，手術後の処置は非常に楽であ る．濃厚なリコールであつても，よく流出するし，患 者は好む体位を取る事が出来る、と云う様な利点があ る.

只，此の方法で一般に心配されるのは，リコールが 出過ぎはしないかと云う事であるが，“実際には余り心 配はいらない. 若し出過ぎる懸念があれば腹位をとら せるだけで充分に調節が出来る。

なお此の方法の可い点は，之によつて治瘾しないま でも，彼の患者を最も苦しめる強度な頭痛が除れる か，或は常に軽減するから，結核性脳膜炎の様なもの にも応用する価值が充分にあると思われる。

然し，以上何れの方法によつてリコールを持続的に 流出させるにしても，最も注意すべき事は水分の充分 な補給である. 田中法によると脳膜炎における1日の リコール流出量は約200〜600ccに上る。:之ほど大量の リコールが流出するのであるから，汗，尿，呼吸によ 
るものを合算すると， 1 日に少く!とも $3,000 \mathrm{cc}$ 前後の 水分が排泄されると見なければならぬ。それを補うた めに経口的に或は注射によつてそれに匹敵するか或は それ以上の水分を供給する必要がある，私共は時々リ コールの流出が良すぎて急激な虚脱をおこす症例にぶ つかるが，その多くは充分な水分の補給によつて予防 し得るようである。

\section{薬物療法}

次に本症の薬物療法に移る。

\section{1. 全身的使用の場合}

\section{化獧性脳膜炎の診断及び治療に関する研究の 3} 化獧性胝膜炎の薬物療法に関する実験的研究

前田謙次郎 日耳鼻 36.10 (昭6. 1)

はしがきの一部。

化膿性脳膜炎治療の原則としては, 先ず原病巣の完 全なる除去. 病的リコールの持続的排泄並に之が補助 としての薬物療法をあげねばならない，そのうち直接 的なリコール管内薬物療法に就いては後述する。薬剤 の内服, 皮下並びに静脈内注射などのいわゆる全身的 薬物療法に当つて，薬剤のうち，どうゆうものがよく リコール内に移行し，又，どうゆう種類の補助薬或は 補助操作がその移行を助けて, 主剤の有効度を増強せ しめるかは, 甚だ重要且つ興味ある問題である.

そもそも脳脊髄膜は，多数先人の見た様に，一種の 透過選択性を有し，その使用法の如何に拘らず正常時 に於ては少数の薬物に対してのみ透過を許し，その他 の薬物には許さない. 然しリコールが一度びその正常 の状態を失うと, 俄かにその許容性が変り, 正常時に 透過可能な物筫は，ますますその移行度を高め, 正常 時には少しの透過をも許されない薬物も，また移行し 得るものがある.之等の事項に関しては，沢山の研究 があり，ほぼその結論を一にしている，透過性の増強 或は異常透過を可能ならしわる様な要約は, 病的脳膜 にあつては益々その威力を発揮する. 従つてかかる要 約を探究する事は, 化膿性脳膜炎の治療面に大なる洒 值を有つ.

\section{結 論}

1. ウロトロピンは静注後 $1 \sim 2$ 時間にしてリコー ル内最高濃度を示し, 約 7 時間に亘つて相似たる濃度 を保ち，60時間前後にして消失する. 但し，此の間， リコール内におけるフオルムアルデヒドの証明は常に 陰性である.

2. ウロトロピンは之を反覆静注してもリコール内 移行度に著しい変化を来さぬ. 少くとも, その減少を
来たす様な事はない。

3. ウロトロピンのリコール内移行の後, リコール を反覆採取すると，多くは，その増加を来たす。

化膿性脑膜炎の治療に関する研究，(その一）

諸種薬剤の静脈内注射による血清並にリコールの

殺菌カの変化について

深瀬亮作 北越医会誌 49.4. (昭和9.4)

第 1 章 白血球像の変化について

化膿性炎症の治療の目的に使用される薬剤の有効度 を測定する一法として，白血球，主として多核白血球 の増加が用いられる。蓋し, 白血球増加は全身反応の 一徴候であつて，自然抵抗力の増強を示す一指針と見 得るからである.

従来, 一ないし種数の薬剤の白血球増加に就いて行 つた研究業績は少くないが，多数の薬剤に就いて系統 的検索を行つたものは殆んぞない. それで私は表題に 揭げた目的の一つとして薬剤の静注による白血球像の 変化, 主としてその増減並びに各種白血球の配分率に 就て検索を行つた。

\section{その 1 実験材料及び方法}

実験には家香を用い，薬剤はエレクトラルゴールの ほか23種である。

注射薬液の量及び濃度は，先に金野がリコール管内 に注射したのと同じにした．蓋し，金野が当時その全 身反応の一所見として血液像を検査し，一定の白血球 増多を見たので, 之と私の静注のものとを比較考察し ようと欲したからである。

此の実験は, 白血球の数量的観察, 質的観察, 白血 球減少症を前駆するか否かによる分類, 白血球増多後 の経過による分類. 最高の白血球堌多を来す時間的分 類, 白血球増多の持続時間による分類なぞにわけられ る.

以上各節に於ける実験成績のうち特に重要な意義を 有する項目のみを選び，之に合格せる薬剤を選出し実 地応用の便に供したいと思う。即ち

1. 綕体的に白血球增多率の高い薬剤

2. 白血球減少症を前駆しない薬片

3. 白血球増多経過中に甚しい動摇のないもの

4. 白血球增多持続時間の長いもの 等である。

エレクトラルゴールは第 3 の条件に於て少しく欠く るところがあるが, その他の条件に於ては, 断然, 他 種薬剤を抜き，大体に於て最も優れた位置を保ち，卜 リパフラビンこれに次ぐ.リバノールはトリパフラビ 
ンに匹敵するが，陰性現象を有する点と使用量の点と に於て注意を要するオプトヒン，ネオアルセミノー ルもまた之に準ずる，以下略。

\section{第 2 章 血清のオプソニン系数及び凝集素の増減 に就いて。}

第 3 章 脳脊髓液殺菌力の増減に就て。

いわゆる血液脳脊髄液関門に就いて，血液とリコー ルとの間には或種の関門とも称すべきものが存在し， 通過物質を選択取捨する機能のある事が明らかにされ ているが，此の関門の透過性は動物の年令的関係，又 は病態関係等によつて一定不変のものではない，即ち 幼若なる動物ではその透過性が高く，また，脳膜の病 的状態にあつては正常時に透過不能なものでも，ある 程度透過せしめる事が判つている。

静脈内に注射せられた殺菌剤のリコール内透過につ いても色々な研究がある．就中，ウロトロピンが正常 動物に於ても良くリコール内に移行する事実は，古く から知られてい，之に関する研究もまた多い。それで 他種の薬郕又は免疫物質の移行を容易にする為に，ウ ロトロピンを用いた者もある．ウロトロピン自身の移 行を助ける補助操作, 補助薬物について前田は精細な 研究をしている。

以上を要するに，正常動物に於て，リコール内への 移行が可能であると明白に証明せられている薬剤は， ウロトロピンが只一つである.

私の研究はその第一として正常家鬼リコールの細菌 に対する態度を観察しているが，リコールの中では黄 色ブドウ状球菌の発育が甚だ悪く，長時間の生存は許 されない，忘はVincent，斎藤，金野らの成績とほほ 一致している。

然し，之を以て直ちにリコールが殺菌力を有つと云 つて可いか否加．栄養素の欠乏による事も考えられる から，すぐには断定できない，然し，血清に殺菌力の 存在を主張する者があるのだから，同じ体液であるリ コールにも，同じ力がないとは云えまい，その力に差 異はあつても，リコールにも相似た殺菌力（少くとも 発育阻止作用）のあるであろうことは容易に想像し得 るし，之が生体の微妙な作用だと私は考えざるを得な い.

以上の私の実験成績では正常家鬼のリコールの中に ブドウ状球菌を入れると，24時間後に全数の約 $1 / 3 に$ 於 て，コロニーの発育を認めない。之はGara, 池上の成 績と一致しない。

薬液を静脈内に注射した場合に，その䯣液の殺菌力
が如何に変化するかを知つておく事は，臨床上重要な 事項である．而も今日までかかる研究には殆んど見る べきものがない．私が此の実験を企てた所以は実に此 処にあるのである. 即ち(1)には端的にリコールの殺菌 力の変化を見度い。(2)には静脈内に注射した薬夜が， リコール内に移行し得るか否を間接的に証明し得るや 否を知らんと欲したのである．例えば，今日正常動物 に於て静脈内注射又は内服によつてリコール内に移行 し得る殺菌郕としては，殆んど唯一のものとも言うべ きウロトロピンに於てすう，そのリコール内に於ける 殺菌機転に就いては明らかにされていない，而も吾々 臨床家は経験上，有効なものと信じ，唯一の薬剤とし て使用しつつある. かかるものに就いて，その分解の 存否は如何にもあれ，果してそのリコールの殺菌力が 増強するや否を，直接に知り得るならば，その使用価 值に一つの有力な根拠を得ることになる訳である。中 略

私の成績を通覧すると，静脈内注射によつてリコー ルの殺菌力を増強する薬物は, ウロトロピンの他にマ 一キュロクローム，ネオアルセミノール，エレクトラ ルゴール等をあげ得る。

その少量を反覆注射した例では比較的大量を一回注 射した例に比べて殺菌力増加の程度が低い．此の点か ら見れば他の所見は暫らくおき，単にリコール内の殺 菌力を増強せしめる目的だけから云えば， 1 回の注射 量の大きい方が可い，と云う事になる。然し，それと ても自ら一定の限度のある事は云う汽もない。

\section{結 論}

以上，私は，エレクトラルゴールほか22種類の殺菌 剤に就て，その静注後に於ける全身血白血球の増減に 関する実験を行い，その中で比較的優秀なエレクトラ ルゴール，トリパフラビン，リバノール，オプトと ン，ネオアルセミノール，ウロトロピン，ジスパルダ ン，ヒノゾール，マーキュロクローム等 9 種の薬剤を 選び，血清中の凝集反応並に殺菌現象等を検査し，更 に同一動物のリコール殺菌力の増減に関する検査を行 つて，全身抵抗力の増強の状態と同時にそのリコール 殺菌力の推移等を観察した。

之等の成績を参照比較して，リコール殺菌力増強の 目的に使用し得る薬剤を選出し，併せて，そのリコー ル殺菌力增強の原因が単に全身抵抗力の増強に因るの か，或はその薬剤がリコール内に移行する為か否を間 接的に考察したのである.

1. 静脈内注射による白血球の增加は，その程度に 
差こそあれ，使用薬剤全部に之を見た。これらのうち 先に述べた 5 条件を参配して，成績順に配列すると次 の様になる。

(1) エレクトラルゴール

(2) トリパフラビン

であつて，

リパノールはトリパフラビンに比肩するが，可成り 高度の陰性期を前駆するからその使用には注意を要す る.

2. 血清中の凝集反応，並に殺菌現象の面から成績 順に配列すると次の様である。

トリパフラビン，リパノール，エレクトラルゴー ル, マーキュロクローム, ネオアルセミノール, ジス パルゲン，ウロトロピン，オプトヒン，ヒノゾール，

此の 2 つの反応は多くは相互して変化する。 そして 一時に大量を注射するよりも，むしろ少量を反覆注射 する方が抗体反応の増強を惹起し易い。

3. 同一動物に就いてそのリコールの殺菌力を検査 し，成績順に並べると次のようになる。

(1) マーキュロクローム，ネオアルセミノール，ウ ロトロピン，エレクトラルゴール，

(2) トリパフラビン，リパノール，プレソョート， ジスパルゲン，

4. 以上の成績を通覧すると, 白血球増加, 血清中 の抗体産生の増强等の著明なもので，必らずしもリコ 一ルの殺菌力を増加しないものがある. 又，これと反 対のものもある、マーキュロクロームの如きがそれで あり，ネオアルセミノール，ウロトロピンなどもまた 之に準ずる，それらの事実からリコール内に於て，最 高の殺菌力を発揮せるマーキュロクローム，ネオアル セミノール，エレクトラルゴールなどは，その幾分か が，血夜からリコール内に移行するのではないかと想 像せられる。

以上の実験成績から見て，私は，ウロトロピンの他 にマーキュロクロームの如き水銀剤，ネオアルセミノ 一ルの如き砒素剤，エレクトラルゴールの如き膠質銀 等も，その容量如何によつて，血液よりリコール内人 移行するのではないかと思うのである.

就中，エレクトラルーゴル，ネオアルセミノール， ウロトロピン等は, 白血球増加, 血清内抗体産生等も 甚だ高度であつて，之に加うるにリコール内殺菌力を も著明に増強せしめるから，化膿性脳膜炎に際し，静 脈内注射用として相互して使用する事が出来るであろ う.マーキュロクロームは白血球増多度は低いけれぞ
も，血清内抗体の産生，リコール殺菌力の増強は相当 高度だから，之また化膿性脳膜炎に使用する事が出来 るであろう。

因みに之等薬物の人体に於ける最大使用量及び普通 使用量を附記すると次のようである。

最大使用量普通使用量

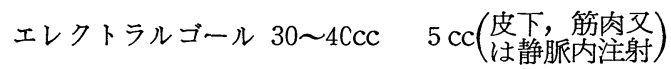

ネオアルセミノール 0.90 (65) $0.15(15) \sim 0.75$ (55)

ウロトロピン 1 日量 $8 \mathrm{~g} \quad 1 \mathrm{~g}$ 内服 $4 \% 5 \mathrm{cc}$ 静注

マーキュロクローム 不明 $1 \% 5 \sim 10 \mathrm{cc}$ 静注

（鳥居記）之は非常に広沉な，また極めて骨の折れ る仕事である. 或る薬剤がリコール内に移行するか否 かを，比色計或はその他の方法で証明する事が出来れ ぼ可いが，それの出来ないものが可成り沢山にある。そ のとき，そのものを注射して果して脳膜炎に効くのか 否かと云う事になる。その様な場合に此の研究の様な やり方をすると,非常に努力の多い仕事ではあるが, 臨 床的には甚だ尊い価値のあるものが出来るのである.

ウラニン及び酸性フクシンの脳脊蹃液内移行要約 に関する実験的研究

深瀬亮作 北越医会誌 49.8. (昭9.7)

私は更に方面を変えて移行物質並びに血夜自身の物 理化学的性状がその移行度に如何なる影響をもつかを 知らんと欲して本実験を企てた。

\section{中 略}

以上述べたように，ウラニン及び酸性フクシンの静 注時におけるリコール内移行に就いては，今や異論の ないところであるが，その報告の多くは，只，リコー ル中の移行度を測定したと云う程度で，その移行の瞬 間における血中の濃度に関しては余り注意を払つてな い様である，血中濃度とリコール内濃度とは，常に一 定の比率を有つと云う事実を度外視しては，血液脳春 骮有関聞の問題を論ずる事は困難である。そこで私は此 の方面に注意を向けつつ先人の業績を追試補足した。

\section{実験材料及び実験方法}

家槵にウラニン及び酸性フクシンを体重毎 $\mathrm{kg} 2.5 \mathrm{cc}$ づつ耳静脈内に注射した。ウラニンでは注射後4C分か ら60分, 酸性フクシンでは30分後に於て各々のリコー ル $1 \mathrm{cc}$ ，血液 $5 \mathrm{cc}$ を同時に採取して検討した。

\section{総括及び考按}

ウラニン（拡散度，8.0）酸性フクシン（拡散度7.0） の拡散度は共に大きい，拡散度の大なるウラニンはそ れより小なる酸性フクシンよりも移行度が大である。 
但し，たとえ拡散度の比較的小さいものでも血中濃度 を高めること（反覆注射等）によつて一定度までその 移行量及び移行速度の増進を見ることは, 杉本の腹腔 内移行試験によつても明かであつて，血液とリコール との間にある程度の移行比率の存在することが考えら れる.

同一総量の薬剤を，その濃度を異にする事によつ て，リコール内移行に差異を生ずるや否やを見ようと 思い，私は同一量のウラニンを $10 \%$ 及び $2.5 \%$ の水溶 液として注射したところ，リコール内移行にはさした る差異を認めなかつた。

ウラニンを主剤として高張食塩水，高張ブドー糖夜 を静脈内に注射し，その移行に及はすす影響を見ると， さしたる増減はないけれども，血中にあるものとの比 率では，著しい低下を見た。

高張液をリコールの中に注射した時は, その量に比 例して, ウラニンのリコール内移行は絶対量も比率も 共に著しい増加を来した。これは明かに高張液注射に よるリコール渗透圧の充進によつて，血中の水分を吸 収すると同時に，その中にあるウラニンの移行を増加 させたものであろう。

\section{結 論}

1. 家象の血中に注射せられた拡散度の比較的高い ウラニンは，それより低い酸性フクシンに比べてリコ 一ル内移行の率が高い.

2. 家鬼の血中にあるウラニン及び酸性フクシンを 一定度迄増量せしめると，リコール内への移行量もま たえに準じて増加する。

3. ウラニンの同一総量をその濃度を異にして血中 に注射しても，そのリコール内移行には著しい差異を 見ない。

4. 高張食塩水及び高張ブドー糖を血中に注射して も，ウラニンのリコール内移行は増強しない，之に反 して，之を蜘蛛膜下腔に注射すると，著るしい移行の 増強を認める.

\section{化膿性髄膜炎の薬物療法に関する基礎的研究}

(第 1-4 篇)

菊池準二 日耳鼻 62.8 (昭和34. 8)

サルフア剤のうち，ドミアン，サイアジン，ズプロ ナールの 3 種の内服並びに静注を行つてそのリコール 内移行を見た。

実験動物. 家鬼

内服では 3 時間後， 4 時間後が最もリコール内移行 濃度の高い時であるが, 血清, 脳延䯋腔リコール, 腰
椎管リコールの三者を同時に比較観察した。 $\begin{array}{lcl}\text { ドミアン } & \text { サイアジン } \\ (\mathrm{mg} / \mathrm{dl}) & (\mathrm{mg} / \mathrm{dl}) & \begin{array}{l}\text { ズプロナール } \\ (\mathrm{mg} / \mathrm{dl})\end{array}\end{array}$ 3 時 4 時 3 時 4 時 3 時 4 時 間値 間値 間值 間值 間值 間値

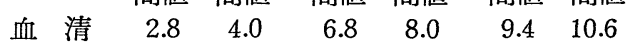

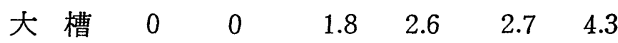

$\begin{array}{lllllll}\text { 腰椎管 } & 0 & 0 & 0.7 & 1.4 & 1.2 & 3.0\end{array}$

即ち此の成績ではリコール内移行度は，ズプロナー ルが最も良く，サイアジンこれに次ぎドミアンが最も 悪いと云う事になる．ドミアンは 4 時間後にも少しも リコール中に移行していない. サイアジンとズプロナ ールでは 3 時間から移行が見られ，ズプロナールでは サイアシシンの約 2 倍量が移行している。

静注。

\begin{tabular}{|c|c|c|c|c|c|c|}
\hline \multirow[t]{2}{*}{ 脬注. } & \multicolumn{2}{|c|}{$\begin{array}{l}\text { ドミアン } \\
\text { (mg/dl) }\end{array}$} & \multicolumn{2}{|c|}{$\begin{array}{c}\text { サイアジン } \\
\text { (mg/dl) }\end{array}$} & \multicolumn{2}{|c|}{$\underset{(\mathrm{mg} / \mathrm{dl})}{\mathfrak{x}^{2} \text { ル }}$} \\
\hline & $\begin{array}{l}30 \text { 分 } \\
\text { 值 }\end{array}$ & $\begin{array}{l}1 \text { 時 } \\
\text { 間値 }\end{array}$ & $\begin{array}{l}30 \text { 分 } \\
\text { 值 }\end{array}$ & $\begin{array}{l}1 \text { 時 } \\
\text { 間値 }\end{array}$ & $\begin{array}{l}30 \text { 分 } \\
\text { 值 }\end{array}$ & $\begin{array}{l}1 \text { 時 } \\
\text { 間値 }\end{array}$ \\
\hline 血 清 & 0 & 7.0 & 0 & 11.3 & 0 & 16.4 \\
\hline 大 槽 & 1.6 & 3.0 & 2.8 & 4.0 & 3.2 & 6.5 \\
\hline 腰椎管 & 1.3 & 2.5 & 2.6 & 3.8 & 3.2 & 6.8 \\
\hline
\end{tabular}

即ち静注では，内服よりは可成り早く，30分後から 既にリコール内への移行が見られる。 サイアジンはド ミアンの約 2 倍, ズプロナールはサイアジンより幾分 多い. 即ち 1 時間後ではサイアジンの約 1.5 倍が移行 している.

\section{抗生物犋（ペニシリン及びストレプトマイシン） の咀道制韩，鹃液内移行並に髄液内に於ける消長 に関する研究}

鹿野秀一 耳鼻臨床 44.11 (昭和26. 11)

ペニシリン，ストマイ等が従来の薬物に優るものと して，全身的には勿論，髄液内一の直接投与によつて 用いられていが，その不快な副作用についての経験報 告も少くない。ペニシリンやストマイが，全身的投与 によつて如何ほど髄夜に移行するか，髄腔内に注入さ れたペニシリンやストマイが，リコール中にどれ位の 時間留まつているか等の問題は，吾々が是非知つてお かるね゙なら重要な事項である、ストマイやペニシリ ンのリコール内移行については，議論が区及である. 正常者では，移行しないか移行しても僅かであるが， 䯣膜炎患者では或程度の移行があると云うのが，今日 の大勢の様である.

此の論文はリコール管内に於ける刺㦸，消長，䯣液 に移行するか否かを見ている，此処には，「第 3 ペニ シリン，ストレプトマイシンのリコール内移行に関す る実験」を抄録する。 
実験には家鬼を用いペニシリン実験群には溶血性 連菌性㕹膜炎家鬼を，ストマイ実験群には結核菌性或 はインフルエンザ菌の代理として $3 \%$ 石松子に因る無 菌性髄膜炎家鬼を使用した。

総 括.

1. 正常の家鬼ではどの使用法によつても，ペニシ リン，ストマイ共にリコール中には移行しない。

2. 実験的哊膜炎家鬼ではペニシリン，スイマイ共 に或程度リコール内へ移行する。 そして頸動脈注射で は筋肉注射よりも移行の機会が多く，移行度も高い。

(1) 此の時, 注射浱度が高ければ移行度もまた高い が，注射濃度と移行の程度とは平行するわけではな い.

(ロ) ペニシリンの筋注では移行しても有效濃度に達 する事は少ないが，ストマイの筋注では低濃度ではあ るが，或程度の有効濃度に達する事がある。

菊池準二はアクロマイシン，テラマイシン，クロラ ムフェニコール，エリスロマイシン等に就いて実験を 行つている. その正常家㭸に於忛る成績を見ると，30 分, 60分後に於いても, クロラムフェニコールを除 き, 筋注でも静注でもリコール内に移行しない。クロ マイとても移行しないか，或は移行しても，30分で血 液中のものの $1 / 30$ 乃至 $1 / 6 ， 60$ 分後で $3 / 50 \sim 0$ と云つ た様な極めて微量である。

髄膜炎家鬼に於忛る成績.この場合に於てもクロマ イのみが，僅にその移行度を高めるだけである．即ち 30分後の成績を見ると, 筋注では零, 静注では4.2 $8 \mathrm{mg} / \mathrm{dl}$ (血中の1/5), 60 分後のそれは筋注で $3 \sim 6$ $\mathrm{mg} / \mathrm{dl}($ 血中の $1 / 6)$ 静注で $3.6 \sim 5.4 \mathrm{mg} / \mathrm{dl}$ で（血中の $1 / 5$ 位).

即ち, ペニシリン, ストマイ, アクロマイシン, テ ラマイシン, クロラムフェニコール, エリスロマイシ ン等の抗生物質は, 筋肉内注射, 静脈内注射を行つて も，何れもリコール内への移行は殆んど望み得ない。

\section{サルフア剂の動脈内注射}

矢部寞 新潟医会誌 63.9. (昭24.9)

家鬼を用いネオテラポールを使用. 動脈注射では, リコールの中に, 15 分後に $4.3 \mathrm{mg} / \mathrm{dl}, 30$ 分後に $3.0 \mathrm{mg} / \mathrm{dl}$ の移行を見ている. 之を血液中の濃度と比較すると， その $54.1 \%$ ４.0\%に達し，静脈注射によるよりも，そ の移行度が余程高い。

髄膜炎患者では此の移行度が更に増加し， $5 \sim 6 \mathrm{mg}$ /dlに達するものを見た。そして急激な経過をとつた 4 症例に応用して， 3 例は治瘜し，脳膿瘍の為に死亡
した他の 1 例でも, 剖見の結果, 脳膜の炎症はその跡 を認め得ない程に治湶していた。また，高熱ある本症 の初期患者に応用して比䑤的速かな段階状熱下降を 見，その血夜像もそれに伴つて正常に復した。

色々な補助操作, 補助薬を使つて，主薬のリコー 儿内移行を增强させる研究

前述した前田謙次郎の「化膿性脳膜炎の薬物療法に 関する研究の第 2 篇」である.

種々なる補助操作, 補助薬物がウロトロピンのリ コール内移行に及ほす影響

その 2 反覆リコール採取が薬物のリコール内透過 に及はす影響。

その 3 種々なる補助莧物のリコール内移行に及は す影響. モルフイン，ピツイトリン，ピロカルピン， 亜硝酸ソーダ，カフエイン，アドレナリン等を使用し た。

\section{結 論}

1. ウロトロピンのリコール内移行後にリコールを 反覆採取すると，多くは，その透過度を高める。

2. モルフイン, ピツイトリン，ピロカルピン，亜 硝酸ソーダ，カフェイン，アドレナリン等のやや大量 をウロトロピンと併用する時は，そのリコール内移行 度を増強せしめる. 就中, ピツイリトン, 亜硝酸ソー ダ，カフェイン並にモルフインに於てその度が強い。 而して，之を最も有効ならしめるには，之等薬剤をウ ロトロピンに先立ち或は少くとも之と同時に使用すべ く，その使用量は許す限り大量を可しとする.

3. 大槽内注射に於いては, 比較的少量を以つて, 相当の効果を期待し得る様であるが，之によつて死亡 する者が多い。

\section{化膿性脳膜炎の治療に関する研究. その 3} 抗体のリコール管内移行に対する補助操作並に補 助薬剤に就いて。

深瀬亮作 北越医会誌 49.8. (昭和9.7)

私も前田の実験を基礎として, 細菌ワクチン及び血 清を主剤として同様の実験を行つた。蓋し, 正常脳膜 に於ける楽剂透過性の増強或は異常透過を可能ならし めるが如き要約の追求は，本症の治療法として大なる 価值があるからである。

実験には家鬼を用い

第 1 群には，感作チフスワクチンを耳静脈内に注射 し, 第 2 群には, 腸チフス血清を同様に注射し, 両群 とも一定時日の後, $1 \mathrm{cc}$ リコール採取と同時に反対 側耳静脈より,或は心臟穿刺により $2 \mathrm{cc}$ 採血を行い， 
血清を分離して稀釈液を作り，リコールおよび血清中 に浅川氏腸チフス診断液の一滴を滴下し，両者の凝集 価を検查した。

結 論

1. 腸チフス血清は，家鬼の静跟内注射後30分にし て既にリコール中に現われ，2〜5時間にして最高の 移行濃度を示し，長時間滞留する．5日後に於てもな お之を認め得た。

2. 腸チフス血清のリコール内移行は, リコールの 反覆採取によつて，その増強を来すものが多い.

3. 蜘蛛膜下腔内にブロタルゴールを注射すると， すべて急速且つ高度に, 血中抗体のリコール内透過度 を高めさせる。

4. 腸チフス血清の静脈内注射に際し，モルヒネ， 亜硝酸ソーダ, ピロカルピン, ピツイトリン，カフェ イン，ウロトロピン等を互用すれば，何れもリコール 内透過を増強せしめる. 就中, モルヒネ, 硝酸ソ一 ダ，ピロカルピン，ピツイトリン，カフエイン等に於 て著明である. 而してこれらの中，モルフイン，亚硝 酸ソーダ, ピロカルピン等は, 血清注射の前後いずれ に用いても可いが，何れかと云えば，モルとネ，亜硝 酸ソーダは血清注射後に，ピロカルピン，ピツイトリ ン，カフエイン等はその前に用いる方が，効果が大き い. 且つこれら薬剤の量は, 多い程よい。

\section{菊池準二の研究}

クロラムフェニコールを主剽とし，補助薬として拡 散因子たるスプラクター，スプラーゼ，血管拡張剤た るメトブロミン，ニコチン酸アミド, 交感神経遮断剤 たるイミダリン等を使用してみた。此の結果では，ス プラーゼ，スプラクター，メトブロミン，ニコチン酸 アミド等を用いる事によつて著明な移行度の増強を見 た.

\section{化膿性脳膜炎の脊推管内薬物療法に関する実験的 \\ 研究}

金野㦑 日耳鼻 38.7.（昭和7.10)

之は広沉な研究であるが，一部を抄録する。

中略

脊椎管内薬物療法において必要な条件は次の 5 項目 である。

即ち

1. 脳膜に対する刺㦸の可及的に少い事.

2. 全身血の白血球増加を招来する力が比較的大な る事.

3. 拡散度の可及的大なる事.
4. 吸収され方が比較的遅い事.

5. 殺菌力の強大な事.

私は従来殺菌剤として使用されている薬物19種を選 んで系統的に観察した。

\section{1. 朕膜刺乾むよび白血球增加におよぼす影響} 実験動物は家宮, 中略.

脳脊髄液の変化において注意すべきは，細胞数と蛋 白質量とが必ずしも平行しないこと．例えば，トリパ フラビンについて見れば, 細胞数の増加は僅か33個を 数えるに過ぎないのに，蛋白質量は $1.32 \%$ と云う異常 の増加を来す。これに反し，エレクトラルゴールでは 細胞数が 1 万を越すのに蛋白量は，最高 0.066 を示す に過ぎい。これと病理組織的変化を併せ考えると， 蛋白量は薬物の刺钱度の強弱と平行して増減するが， 細胞数は必ずしもそうでない，と云うことが判つた。 それで，私は蛋白質量を標準にして，その刺㦸度を比 較し，次の 6 群に分けた。中略.

即ち大体においてこの成䋶は Schmutter 笠原教授 の組織学的検索と一致している.

\section{血液像に及はす影響}

何の薬剤を注入した場合に，全身血に，最高の白血 球増加を来たすかを見た．中略．即ち血中の白血球増 加率も，一定限度までは脳膜の刺㦸度と一定の関係を もち，刺㦸の弱いもの及び刺㦸の強きにすぎるもの は，何れも白血球増加の度が低い。

家験の2. 薬物の拡散および吸收 中略

15分にして大槽に達し，㧫も最高濃度に達する時間 は, 大体に於て, 試験管内の拡散度と平行し, 固有拡 散度の高い薬物は極めて速かに大槽に達するが，吸收 されることもまた速い。

\section{実験の 3 薬物の殺菌力. 中略.}

実験の 4 治療及び予防的効果.

以上種々なる条件の下に於て，私は，ジスパルゲン コラルゴール，ヒノゾール，ウロトロピン，オプトヒ ン，エレクトラルゴールの 6 種を選出し，之等の治療 的並に予防的効果を検査した。即ち頭蓋腔を開いて脳 硬膜下腔に連鎖状球菌或は肺炎双球菌浮游液を注入 し，薬夜は第 5 腰椎弓截除部より注入した。治療的に は薬液を細菌注入と同時に，又はその後に，状況に応 じて注入し，予防的には 1 日 1 回乃至 5 回，薬夜注入 後に細菌を接種した。

之によつて次の様な成績が得られた。

1. ジスパルゲン，コラルゴールに於ては何らの効 
果をも認め難い.

2. オプトヒンに於ては，治療的には 3 例中 1 例の 治瘜を見たが，予防的効果は認め難い。

3. ヒノゾールでは治療的効果を認め難いが，予防 的には12頭中 1 頭の治瘾を見た他，予防的注入回数が 多いものほど生存日数が長かつた。

4. ウロトロピンでは治療的効果を認め難いし，又 予防的にも16頭中只 1 頭の治痹を見ただけで，他は皆 1 ～ 3 日で死亡した.

5. エレクトロラルゴールは治療に於ても 6 頭中 2 頭の治瘾を見, 予防的にも15頭中 5 頭の治瘜を見た。 即ち以上私の選出した薬剤のうち最も良好な効果を示 し，就中，予防的使用は治療的使用よりも效果が多い 様である。

\section{化膿性脳膜炎の治療に関する研究，その 2}

\section{血清ワクチンむよびコクチゲンの脊推管内注射療}

法 附, 脳脊䯣腔内の局所免疫に就いて.

深瀬亮作 北越医会誌 49.8（昭和9.7)

脊椎管内の薬物療法に就いては, 先に吾が教室に於 て金野の研究がある.これによつて最早や行詰りの感 があつたこの方面に，一縷の光明が投げられ，更に吾 々の検討によつて，なお，若干の希望のあることが考 えられて来た。流行性脳脊髄膜炎に対して血清治療が 著効あるに拘らず，他の化膿性脳膜炎に於てはその効 果が甚だ少なく, 治験例も余りない.中略. 化膘性脳 膜炎の脊椎管内免疫及び血清療法に関する研究の成績 は区々であるが，肺炎双球菌性脳膜炎の治験例のや > 多い事が注目される。

\section{実験材料および実験方法}

動物は家鬼。注射材料にはブドー状球菌, 肺炎双球 菌, 連鎖状球菌及び粘液性球菌の 4 種を選び，そのワ クチン (北研製) コクチゲン（鳥潟研究所製）で，之 等を蜘蛛膜下腔に注射し，血清には肺炎双球菌及び連 鎖状球菌血清を使用した。

\section{綜合的観察および考安}

ワクチン及びコクチゲンを予防的に使用してたもの では，70例中 8 例の治瘜を見，その治傯に至らなかつ たものも, 対象に比し生存日数に於て，1.3 及至 3 倍 の延長を見ておる. かかる局所免疲の獲得は, 菌種に よつて大きい差がある様である. 即ち, 私の成績で は, 連菌, 肺炎菌, 葡菌の順で, 粘夜性球菌では之を 認める事が出来なかつた．次に，ワクチン及び，コク チゲンを治療的に使用したものでは，26例中 1 例の治 瘾もなく，肺炎菌及び連菌に於てのみ対象に比し， 1.6
乃至1.8倍の生存期間の延長を見たに過ぎない.

次に肺炎菌および連菌の血清使用例を見るに，その 予防的効果は, ワクチン及びュクチゲンよりも遙かに 大であつて，44例中 9 例（20\%）の治瘜を見，特に肺 炎菌に於て甚だ良い成績を示した。

肺炎菌及び連菌の血清を細菌の感染後に使用したも のでは，24例中僅に 1 例の治瘾を見た。この成績は諸 家の臨床経験に一致するものであり，Kormerの動物 実験成績とは一致しない.

ワクチンとコクチゲンの効果を比較するため，予防 的に使用した成績のみを見ると，その間に著るしい差 異はないが，強いて言えば，肺炎菌及び葡菌に於ては コクチゲンがや>優り, 連菌に於てはワクチンがや > 優勢である。

私はこの実験に当り, 対象動物として何等の処置を 施さないものと, 血清, ワクチン及びュクチゲンを静 脈内に注射したものとの 2 種を作つた. 後者の静脈内 注射群では，1例の治瘜も見られなかつた。これによ つて見ると，か〉る免疫体の静脈内注射によつて化膿 性脳膜炎を治瘜せしめることは至難であるといつて良 い. 従つてワクチン類の春䯣管内注入によつての免疫 獲得は, 村山, 野村, 増谷等の云うが如く, 脳春髄䐋 に於ける所謂局所免疫成立の結果であろう.

\section{サルフア剂の脊椎管内注入療法に関する研究}

\section{三林茂雄 (未発表)}

三林茂雄怯レギオン，テラポール，トリアノン，サ ルゾールに就いて比較研究を行つた. 髄膜刺㦸の比較 には一般症状, 体温, 血液像, 髄液の変化及びレック リングハウゼンの生体内鍍銀法を行つて, 脳軟膜の内 被細胞の变化を見た。

此の実験成績からスルフアミン剤を髄管内に注射す る場合には，市販品を更に稀釈して用いないと危険で

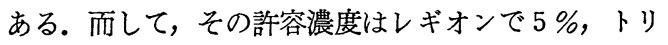
アノンとテラポールでは0.5\%, サルゾール $1 \%$ そ, そ の量は体重 $1 \mathrm{~kg}$ 当り $0.1 \mathrm{cc}$ である事が判る. 又，スル ファミン剤注入時に見られる副作用のうち, 全身症状 で注目されるのは, $\mathrm{pH}$ 低いテラポールでは四肢の麻 瘦と縮瞳であり, $\mathrm{pH}$ 高い残りの 3 者では四肢の痤攣 であつた。

かかるものを剖見すると，脳底軟膜及び軟膜腔に出 血を認め, 注入部位附近では, 脳実質にも出血を認め るほか, 旰, 脾, 骨䯣等に著明な退行変化を認める.

なお注意すべきは，対照実験として行つたリンゲル 液注射でも, 脳脊髄軟膜, 並に脳脊髄実質に著明な充 
血を認める事である。

菊池準二の研究

その他のスルファミン郕, ドミアン $(1.0 \%)$ ズプロ ナール $(1.0 \%)$ ，サイアジン $(1.0 \%)$ の他にレギオン

( $5 \%)$ テラポール $(2.5 \%)$ サルソール $(1 \%)$ につ いて菊池は三林と同様な基準で刺践度を比較研究し た。これらを刺㦸度の小なるものより順序に並べる に，次の様になる。
1. ドミアン
2. レギオン
3. トリアノン
4. サイアデン
5. テラポール
6. ズプロナール
7. サルゾール

抗生物咀，ペニシリン及びストマイの咀膜刺载並 びに腰椎管内消長に関する研究

鹿野秀一 耳鼻臨床 44.11 (昭26.11)

その1，ペニシリンの髄膜刺㦸に関する実験.

薬物つ髄膜刺㦸は薬物を䯣腔内に注入したのち，一 般状態, 体温, 血夜の白血球数並に像, 髄夜中の細胞 数並にその種類，総蛋白量の変動等を観察する事によ つて推察ができる.

著者がいろいろな濃度のペニシリンを家鬼の蜘蛛膜 下腔に注入し観察した成績は次の通りである。

1. ペニシリンを髄腔内に直接注入すると或る程度 の髄膜刺㦸が見られる，純度の低いものは，その高い ものよりも刺戟が大きい.

2. ペニシリンの濃度が高いほど刺㦸も強い.

3. 溶媒による差異は少ない。

4. 1 回の注入では24時間後に刺㦸消失の徴候が見 られる。

5. 連続注入を行うと刺䇅は或る程度増大する。

6. 家鬼では 500 単位以下ならば刺皒が比較的少な W.

その2, ストレプトマイシンの髄膜刺㦸に関する実 験.

1. ストマイも髄腔内に注入すると或る程度の刺㦸 作用を発揮する。

2. 注入濃度が高いほど髄膜の刺钱度は大きい。

3. 1 回の注入でも 24 時間後に於てなお刺战状態の 残存が見られる。

4. 連続注入では或る程度に刺㦸が増大する.

5. 家躳では $1 / 200 \mathrm{~g}$ ならば，刺㦸が比較的に少な
い.

その 4 ペニシリン，ストマイの髄液内に於ける 消長に関する実験

ペニシリンとストレプトマイシンをそれぞれ家雭の 骮迶腔内に注入し，一定の時间每に髓夜を採り，その中 のそれぞれの濃度を前と同じ方法で測定した。その成 績によると，

正常家鬼でのペニシリンのリコール内に於ける消失 は比察的速やかであり，ストレプトマイシンの消失は 徐アである。即ちぺニシリンは実験の注入濃度では, 長くとも 8 ないし 9 時間, 多くは 7 時間近くで有効濃 度以下となり，遂に証明せられなくなるが，ストマイ は24時間後に於てもなお存在し，而も有効濃度を保持 する.

此の事実は，先に述べたペニシリンの髄膜刺㦸が 24 時間後に消失の徴を見せるのに，ストレプトマイシン では24時間後にもなお刺㦸の残存が見られる事の多い と云う実験成績を裏書きする。

\section{化莀性脑膜炎のガス療法に関する実験的研究}

林啓介 北越医会誌 58.2.3.4（昭18.2.3.4）

ガス療法に関しては1933年 Osker Zeller が人体 に於て，従来の洗滌夜に代えるにガス体をもつてし， 刺战の弱いアセチレンガスは窒素並に酸素ガスに優る と説き，同年 A. Jauerneck は同氏の方法に従い， 8 症例にア七チレンガスを注入して 4 例の治傯を見， 更に1935年には25例の中10例の治瘜を見た。この事か ら吾が国でもガス療法が急に取り入れられて来たので あるが，此の実験的研究が余りないので，林は茹に基 礎的研究を計画した。まず代表的ガス体として 5 種を 選び，実験的化膿性脳膜炎家霓の蜘蛛膜下腔にいろい ろな条件の下に注入を行い，その影響を追求した。そ の成績は次の通り。

その 1、実験的化膿性脳膜炎に及ぼす各種がス体 の蜘蛛膜下腔注入による治療的効果に就て。

諸家の説並に私の実験成績から，化膿性脳膜炎の力゙ 又療法に期待し得る効果は。

1. ガス体は比重が軽いので上方に昇る．脳脊髓液 中を上昇してこれを下方に圧迫して，大量の病的リコ 一ルを排除する事ができる。

2. 多量のリコール排除により起り易い，急激且つ 過大な液圧の低下を防ぐ事が出来る.

3. 脳嗼の痹着を防ぎ，リコールの分泌を高め，そ の循環を円滑ならしめる.

4. ガス体は薬夜より良く線維素性物質を透して拡 
散する事が出来る.

5. ガス体は種々の脳脊髄夜腔洗條夜に比し，脳膜 並に脳実質に対する刺㧔性が少なく，副作用も少な い.

6. ガス体の注入は, リコール並に血中の白血球増 多を促進し，脑膜炎に対して良い影響を与える。

7. ガス体の注入は体温を下降せしめ, 治瘜機転に 好影響を与える.

8. 脳脊䯠腔に注入した薬物の拡散が，ガス注入に よつて促進される。

9. ガス注入は血液中なる薬剤のリコールへの移行 度を高める。

\section{総括並びに結論}

私は実験的化膿性脳膜炎家鬼にいろいろの条件下で ガス体を注入し，その影響を検索して次の結論を得 た.

1. 各ガス体とも実験的化膿性脳膜炎家鬼の治瘾機 転に良い影響を与えるが，就中，アセチレンガスとエ ーテル蒸気の二者が最も優れている. 炭酸ガス, 酸素 ガス，フオルマリン蒸気等は之に次ぐ.

2. 各ガス体とも，12時間毎の注入が著効を示し， 5 時間毎の注入は殆んど効果がない. 但し病状の経過 に応じて，此の注入間隔を適当に考慮する要がある. 之によつて更に大いなる効果をあげ得るであろう。

3. 細菌注入 3 時間後よりガス注入を開始したもの の治瘾率が最も高く, 細菌注入の直後より開始せるも のがこれに次ぎ，12時間後より開始したものは，エー テル蒸気を除いて，成績が良くない。

4. 各ガス体とも全身症状には殆んど影響がなく， 只, エーテル蒸気で一過性の刺㦸症状を見たのみであ る.

5. ガス注入の直後に体温の降下を見る. 之はエー テル蒸気に於て最も著明であり, フォルマリン, 酸素 ガス，炭酸ガス等之に次ぎアセチレンガスが最も軽微 である.

そして，かかるガス体の効果は, 脳膜炎の急性期, 即ち体温の高い時期に著明であつて体温の正常に近ず

\section{くに従つて減少する。}

\section{その 2 各種ガス体の正常家鬼蝴蛛膜下腔注入に} よる一般症状，特に体温，血液像並にリコールの 所見に就いて

1. ガス体注入による一般症状, 体温, 血液の白血 球総数並に脳脊髓夜所見の相関々係。

2. 一般所見，体温，白血球総数並にリコール所見
の総括的立場から見た各種ガス体の脳膜刺㦸程度の比 較

総 括

1. アセチレンガスが刺战性最も弱く，対照実験に 於けるものと大差がない.

2. 炭酸ガスは之よりや>刺㦸性であるがその程度 は極めて軽微である。

3.エーテル蒸気は, 体温並にリコール所見の変動 が著明であるけれども，白血球総数の変動度が低く， 而かも何れの変動日数も短い. 只, 注入時に軽度の刺 战があるが一過性である. 即ちその刺钱性は炭酸ガス にや>優ると見てよいだろう。

4. 酸素ガス, 空家並にフォルマリン蒸気はその刺 皒性が相似ているが, 体温の変動は酸素ガス, 空気, フオルマリン蒸気の順につよく, 白血球総数の変動 は, 酸素, フォルマリン蒸気の順につよい. 即ち, そ の刺㦸性は空気と酸素は相似ており, フォルマリン蒸 気が中でも最も大である．之等 3 種のガス体について 各々の変動の程度並に変動日数等を合せ考えると, 脳 脊㕼腔内に於ける被吸収速度は空気, 酸素, フォルマ リン蒸気の順に大である.

以上 6 種のガス体の刺钱性を, リンゲル液に比較す ると，6種のうち刺㦸性の最も強いフオルマリン蒸気 が略々同程度である.

それでアセチレンガス, 炭酸ガス, エーテル蒸気, 空気, 酸素ガス並にフォルマリン蒸気の 6 種は, 何れ も, 安心して臨床的に応用が出来る. そしてエーテル フォルマリン蒸気等の殺菌力, アセチレンガスの麻醉 性, 炭酸ガスのアルカリ性等を適当に按配すれば，恐 らく単独使用に勝る効果を期待しうるであろう。

塩素ガスと亚硫酸ガスは全身に及はす刺戟がつよく 或は注入後に間もなく死亡し, 或は体重の減少, 衰弱 等を来すので臨床的応用は全く不能である.

\section{その 3 各種ガス体の蝴蛛膜下注入が脳軟膜内被 細盷に及ほす影響に就いて \\ 結 論}

健康家鬼の蜘蛛膜下腔に各種ガス体を注入し，之が 脳軟膜の内被細胞に及浔す影響を生体内被細胞鍍銀法 によつて観察した。

1. アセチレンガス並に炭酸ガスに於ては，対照と 同じく，内被細胞への障碍は殆んど認められない。

2. エーテル蒸気, 空気並に酸素ガスでは極めて軽 微の障碍が見られる.

3. フオルマリン蒸気の障碍度は相当に大きい。 
4. 塩素ガス並に亜硫酸ガスの障碍度は極めて大き く，中でも亜硫酸ガスが強い.

以上を要約し障碍度の軽いものから重いものへの順 に列記すると，

1. アセチレンガス並に炭酸ガス

2. エーテル蒸気；空気並に酸素ガス

3. フォルマリン蒸気

であつて，塩素ガスと亜硫酸ガスは，障碍が甚だ高 度で，使用に堪えない。

\section{その 4 各種ガス体の脳膜剌聝に関する一般病理 組織学的研究}

結 論

上述の実験成績から次の如く結論する。

1. 各ガス体の注入による一般病理組織的変化は， そのリコールの中に現われる総蛋白量とほほ平行す る.

2. 炭酸ガス，エーテル蒸気，アセチレンガスの 3 者では，その変化が軽微である。

3. 酸素ガス, 空気, フォルマリン蒸気の三者で は，変化が著明であるけれども，脳脊髄の実質には著 変を来さない。

4. 塩素ガスと亜硫酸ガスでは，その変化が高度で 脳実質内にも出血を認める。

\section{耳性化膿性脳膜炎の治療に就て}

鳥居恵二 北越医会誌 53.12（昭13.11）

本症も近年の研究，特にその外科的処置によつて早 期のものだけでなく，大脳凸面にまで拡大した相当高 度のものでも霋々治療に導びき得る様になつた事は非 常に喜ばしい: 中略.

本症治療の主要点は申すまでもなく，

1. 診断を出来るだけ早期につける事で，今日まで の症例を集めて見ると，発病 2 日以内に適当の処置を したものは多く治癒し，それから遅れたものは大抵死 亡している.

早期診断については获に詳しく述べないが，只，一 言申し述べたいことは，項強直とか，ケルニヒ症状等 を目標にしては遅すぎると云う事であつて，之等は脳 膜炎の完成した症状である，それゆえ，その他で疑い のおける症状が出た場合には，躊躇なく腰椎穿刺な り，後頭下穿刺なりを行い，且つその肉眼的検査に満 足する事なく，グロブリン反活と細胞数の検査だけは 絶対に怠つてならないと思う。と云うのは，外観の透 明なもので，既に相当多量の蛋白質を含有しているも のがあるからである。
原病巣の完全な除去, 内耳手術の意義。

次には原病巣を発見して; これを出来るだけ完全に 除去することに努めなければならぬ。ところがお互に 経験しているように，中耳手術に際し，S状洞の変化 亡か，脳硬膜内外の異常とかの如き，著明な变化があ つて，脳膜炎の原因地及びその伝染経路を推測し得る 場合は，寧しろ少なくて，いかなる伝染経路をとつた か不明のことが多い.この様な場合には，よく，うや むやに葬られがちである，Zange の内耳性脳内合併 症の剖見成績を見ると，その80\%が化膿性脳膜炎であ ると云う事，その後いろいろの人によつて経験された 様に，内耳性脳膜炎と云うものの中に内耳自身の炎症 は極めて軽いものがある，例えば軽い漿液性内耳炎か らも雯々脳膜炎の起る事汃明らかにされている．従つ て臨床症状から見れば内耳炎の症状を現わさないもの でも，脳膜炎を起し得ると云う事実，並に内耳より深 部の錐体内に於ける炎性変化から脸膜炎を起す事のあ る経験. 之等の重要な理由から原因地及び伝染系路が 明らかでない脳膜炎に於ては，単に中耳根治手術に止 まらず，内耳摘出を行う事が必要不可欠である。

此の様な内耳手術によつて，外国に於ては勿論，本 邦に於ても既に少数ではあるが，治験例を持つ様にな つた。それは，之によつて錐体内の病的箇所を殆んど 完全に除去し得るからである。

\section{3 脳脊咀液排除の方法}

次には髄管内に入つた炎症をどの様にして治癒に導 びくかと云う問題になる。それにはリコールの排泄を 計ると云う事が第一であつて，腰椎穿刺もその一方法 である，之を反覆施行する事によつて，治瘾した症例 もある。

前田の研究によると，腰椎穿刺後には，著明な白血 球増多を来たす，之によつて，全身の抵抗を高める事 がその有効な理由の一つであるらしい. 此の意味で穿 刺を続行し，比較的長い日時に亘つて，白血球増多の 状態を持続させ様とするのには，連日これを行うょり は，1 万至 2 日の間隔をおいて穿刺を反覆するのが可 いと云う。

持続的排泄に就いて

一時的な第刺でも良い結果があるとすれば; むしろ これを持続的に行つてはどうか，と云う事が考えられ て来る。

耳性脳膜炎の始めは大抵，脳底脳膜炎であると云う 事, 内耳性脳膜炎では，主な感染䒺路が内耳道である と云う事から，その開くべき場所は，脳底か或はその 
近所で内耳道に近く，リコールを多量に眝えていて， 開いた創面が容易に閉鎖しない籄所と云う注文がつけ られる，すると脳橋槽が最も之に適している事にな る. 即ち内耳道から入つて行けば, 此の槽に容易に達 し得る.

\section{脳橋槽の開放}

内耳道を開放するには 2 つの道がある。 その横に於 て開いても繸に開いても一時は良く排泄がつく，が， 多くは，1 週間内外で排泄が止る事を吾々は経験し た。その上に顔面神経麻痺を来たす場合が多い，それ で私は一昨年来, 此の内耳道開放をやめ, 内耳道の直 後方に於て開く方法を考按した. 即ち脳硬膜を露出さ せ，内耳道になるべく接近した位置で，之を上下に又 は必要に応じ丁字型に開く（此の際，上下岩様骨静 脈洞を甥つけないよう注意)。怅の方法によれば，顔神 麻痺を起さないですむばかりでなく，リコールの排泄 も長く持続し，18日ないし21.日間に亘つて盛に流出を 見たものがある.

以上の様に脳橋槽の開放を行つても，まだ治らない ものが経験された。 その様なものを剖見してみると， 脳底のその側では治瘾しているのに，反対側ではまだ 高度の炎性变化があり, それがら大脳凸面に向つて拡 大せる状態を見た。

そこで此の様なものには, 反対側の乳様突起をも開 いて，対孔を作ればよかろうと云う考が起つて，1〜 2 試みた症例もある。然し，此の手段は，いろいろの 事情で行い難い場合がある。例へば骨質が非常に緻密 で硬いものでは，さらでだに安静を要する患者に，更 に強い頭部振蕰を加えることになるし，又，錐体の構 造によつては，内耳の一部を傷つけないと，巧く行か

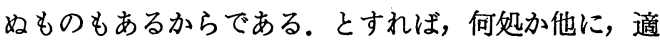
当な対孔の設置場所はないだろうか.

多くの人ダ経験している様に，脳底脳膜咨でも，炎 症は早期に於て既に脊椎管内に拡大しているものであ る.

Bilkholz に従えば, リコールの全量は120ceであつ て，その半分が脊椎管内に入れられていると云う。

その様に大きな脊椎管内の化膿をも, 頭蓋腔の 1 力 所の排泄孔によつて治瘜させ様と望むのは少々無理で ある。

一般外科の知識から云つても，大きな化膿巣を只 1 っの排泄孔のみで治瘾させ様とする事は誼つている.

すると脊䯣管の何処かに対孔を作ればよいではない かと云う考えが浮ぶ.そこで問題になるのは，後頭下
窩と腰椎管であるが，前者には色々の不便と危険があ つて，到底後者には及ばない。

腰椎管を開いた治験例の報告は未だない様である。 私は最近 3 例にこれを試み 2 例が幸いに治痛した。

腰椎管を開くには，第 3 第 4 腰椎部を選ぶのが最も 良い，仙骨部は管腔の浅い利点はあるが，術後に創面 が污染され易い欠点がある. 腰雄弓切除術時の皮膚切 線は, 約 $10 \mathrm{~cm}$, 管腔を開く長さは縌に $1 \sim 1.5 \mathrm{~cm}$ とし, 管腔にはタンポンも排膿管も入れないで，只，皮膚と 筋肉の創面が傯着しないようガーゼで被い，太いゴム 管ようのものを挟み哆開させておく，此の手術で重要 な点は，䯣管を開くまでに，あらゆる出血を完全に止 めておく事である.

リコールの圧が高い時は，管腔を開くと同時に，リ コールは噴出するが，呀刺後などであると，直ぐには リコールの流出を見ない事がある. その様な時にも， 管腔をいじりまわす様な事をしないで，静かに放置す る. 液圧が高くなれば自然に流出する.

此の手術を行うと，リコールの排泄は非常に良い。 1 日 3 回以上のガーゼ交換が必要な程である.

此の排泄は20日前後に及ぶ。更にこの対孔がつけら れたことによつて，一旦排泄が中止していた脳僑槽の 開放部からも，再びリコールの流出を見る様になる。

その大きな皮膚切開創も，リコールの流出が止んだ 後は，極めて速く閉鎖するし，又，下肢の麻痺，大小 便の排泄障碍等, 吾々の心配していたような後遗症は 少しも残さない.

要するに，耳性化膿性脳軟膜炎で原因地及び伝染経 路の不明なものでは, 内耳摘出を行う事, リコールの 排泄法としては, 脳橋槽を内耳道の直後方で開放する 事，これでな稀経過が悪ければ，2～3 日の中に腰椎 管を開放する事である。

脳質乾燥症を起す危険があるから，2籄の大きな排 泄孔を同時に設ける事は避くべきであろう。

\section{化膿性脳膜炎の内科的療法}

鳥居恵二 耳鼻臨床 43.3. (昭25.3)

本症の治療は

1. 原病巣の徹底的清掃 と除去

2. 病的髄液の大量排除

3. 薬物その他の療法

に大別されるが，うち内科的療法に属するものにつ き，私の教室に於て行われた研究を中心として述へて 見よう。

1. 髄管穿刺療法 
2. 髄管穿刺と頭部蘶血療法

3. 髄管の洗滌療法

4. 髄管のガス療法

5. 薬物 (広義) 療法

此処では薬物療法についてのみ述べる。 薬物療法

此の目的に用いられるものに, 色々な薬剤, 血清, ワクチン，抗生物質等がある。

之等の使用に当つて，薬物を直接髄腔内に入れる方 法では, 脳軟膜及び脳質が容易に障碍される事, 全身 的使用では血液䯣夜関門の選択作用に遮られて，リコ ール内に移行しないものがある事等が問題になる。血 液リコール関門の選択作用が脳膜炎時に低下する事は 事実であるが，大体は正常時のものが標準になる.

従つて各薬物に就て之等の性質を知つておかねばな らない。

1. 全身的使用

此の際には吾々は $2 つ の$ 希望をもつ

1. 全身の抵抗を増强させる。

2. 髄夜内に移行して病巣にも直接作用する事であ る.

後者の証明には比色法や化学反応を用いたが，その 何れもが不可能なものには，その前後に於けるリコー ルの殺菌力の比較試験で決定した。

深瀬は之等の法を用いて22の消炎殺菌剤に就て色々 の角度から比較検討し, 次の如き成績を得た。

これ等全身的使用でリコール内に移行し得るものを

5 種あげると次の様である.

エレクトラルゴールとトリパフラビンは, 同時に全 身的にも良い影響を与えるので，優秀な薬品であり， ウロトロピン，ネオアルセミノール，マーキュロクロ 一ム等が之に次ぐ.

前田はウロトロピンの使用に就いて, 次の事実を明 らかにした. ウロトロピンは静注後 1〜2時間から約 7 時間に亘つてリコール内に於て最高濃度を保ち，反 覆注射を行つても有效濃度が変らない.そこでウロト ロピンを最も有効に使用するには，約 5 時間おきに静 注を続けるのがよい。

\section{薬物の㩆液内移行增强法}

上記の薬剤が静注によつてリコール内に移行し，効 果を発揮するならぼ，可及的にそれらの大量をリコー ル内に送り込む事が望まれる. その手段として(1)大量 使用 (2)補助操作 (3)補助薬が考えられる. (1)には当 然, 限度があるから (2) と（3)の方法が研究の対象に
なる.前田の研究によつて次の事が明らかになつた。

1）主剤の静注後にリコールを反覆採取する.

2）モヒ，ピツイトリン，ピロカルピン，亜硝酸ソ 一ダ，カフエインなどの出来るだけ大量を主㓮使用の 前後に投与すれば，主剤の移行度を著るし（く高め得 る.

樑瀬(亮)の血清のリコール内移行に関する実験でも 同様の成績が得られた。

サルフア剂その他

上記の研究の後に, サルフア剤やペニシリン刻, ス トマイ等の抗生物質が登場したのであるが，サルフア 剤は全身的使用でリコール内によく移行するから，上 記の薬物と同様に全身的に使用するのがよい．

矢部寛はサルフア剤を頸動脈に注射すると，静注の $2 \sim 3$ 倍の移行がある事を確めた。即ち，注射後15分 におけるリコール内サルフア剤濃度を見ると，動注で は $6 \sim 9 \mathrm{mg} / \mathrm{dl}$ であるのに, 静注では $2 \sim 3 \mathrm{mg} / \mathrm{dl}$ に過ぎない。

ペニシリンとストマイの両者は全身的使用では，リ コール内に移行しない.だから重症では全身的使用の 他に，少量の髄管内注入が行われている。

\section{2 髄管内薬物注入療法}

a 血清，ワクチンおよびבクチゲンの髓管内注射 深瀬(亮)は実験的研究から次の結果を得た。

1）家鬼の蜘蛛膜下腔に連菌, 葡菌, 肺炎菌等のワ クチンやコクチゲンを注射しておくと同名菌の感染に 対して予防的効果がある. 然し, 感染後に用いるので は無効である。

2）肺炎菌，溶連菌の血清は，同名菌の感染に対し て，ワクチンやコクチゲンよりも遥かに䂆方的効果が 大であるが，感染後に用いたのでは無効である.

つまり，ワクチン，血清ともに予防的効果はあるが 治療的勃果はない。

3）ムコーズス菌では，ワクチンおよびコクチゲン は予防的にも治療的にもともに無効である.

b) 薬物（狭義）の䯣管内注入療法

此の方法では, 時にショック死や脊髄横断症を起 し，或は一時的刺㦸症状が出るので，極めて慎重に行 わねばならない。

この事実は金野(敩), 深瀬(亮), 三林 (茂)らの基 礎的実験から明瞭にされた。

金野は22種の薬剤を用い，次の条件を入れる楽剤の 存否を追求した。

1）脳軟膜や脳実質に対する刺战性の少いもの. 
2）拡散度の高いもの.

3）被吸収速度の大なるもの。

4）殺菌力が強くて，高い稀釈に堪えるもの.

5）同時に全身血に白血球増加を招来する力の大な るもの.

実験方法としては，或は物理学的に拡散度を調へ， 或は動物を用いて生体反応と病理組織的像を見，或は 細菌学的に殺菌力の比較を行つた。

この実験から次の 6 種が選ばれた。

エレクトラルゴール，ヒノゾール，オプトヒン， シ スパルゲン，コラルゴール，ウロトロピン

之ら以外の18種の薬剤は, 病理組織学的に見て脳軟 膜や脸実㬴に出血，溢血，細胞浸潤等を起し；脊髄横 断症：ショック死などを起すので使用に堪えない。

次に金野は以上 6 種の薬剤を家鬼の実験的脳膜炎 （肺炎菌と溶連菌）の予防及び治療に試用して次の成 績を得た。

1）エレクトラルゴールは最も優秀で，予防的にも 治療上にも極めて効果的である.

2）ヒノソ゚ール，オプトヒンは前者には劣るが，予 防にも治療にも或程度の期待をかけうる.

3）その他のものは総て無効である. ウロトロピン は深瀬の全身的使用実験では優秀な成績を示したのに 金野の髄管内使用では無効である事に注目せねばなら ぬ.

以上の事から，吾々が安心して髄管内に注入し得て 而かも治療効果の期待できるものは，22種の薬剤のう ち僅に2,3 種に過ぎず，他は無効であるのみならず， 脳膜や脸実質に高度の障碍を与えるのである。

\section{三林(茂)のサルフア斉!鹃管内注入実験}

サルフア剂は全身的使用で良く髄管内に移行する。

一方，之を髄管内に注入して重篤な副作用を見た報告 が，屢々見られる．従つてサルフア剂は須らく全身的 に使用すべきである。

三林(茂)は市販のサルフア剤を色々の濃度に稀䣋し て，体重 $\mathrm{kg}$ 当り $0.1 \sim 0.2 \mathrm{cc}$ ずつ家鬼の髄管内に注入し その全身症状, 血液, リコールの変化, 病理組織像な ぞから次の結論を得た. 即ち, サルフア剤は市販品を 更に稀釈したものでも一定濃度以上のものは危険であ る.その許容濃度はレギオンでは $5 \%$ ，テラポールと トリアノンでは $2.5 \%$,サルゾールでは $1 \%$ で，而もそ の量は体重 $\mathrm{kg}$ 当り $0.1 \mathrm{cc}$ である.

之らの副作用のうち，全身症状で注目されるのは， $\mathrm{pH}$ の低いテラポールでは四肢の麻痺と縮曈であり，pH
の高い3 者では四肢の痤攣である。その他一般に肝， 脾に著明な退行変性が見られ，骨髄むまた高度に侵さ れる.

\section{筆者の苦い経験}

筆者はサルフアダイアキンを脳膜炎患者の腰椎槽に 注入して，堪えがたい頭痛並に激しい下肢の疼痛と発 熱を来たした例を 2.3 経験したが，更にペニシリンで は致死的の障碍を来たした症例を経験した。

第 1 例はムコーズス菌性脳膜炎であるが，橋槽から 4 日間 6 回，総計 42.500 単位を注入. 第 2 例は普通の 脳軟膜炎で腰椎槽から 4 日間10回, 総計 128.000 単位を 注入，何れも直後からリコールの流出が覀くなり遂に 死亡した。

剖見所見では，脊髄の周囲が厚い淡黄緑色の外套で 包まれ，その最も厚いところでは，脊喵自身の横断面 に匹敵するほどである。此の変化は注入部付近におい て最も強く，腰椎槽に注入したものでは，馬尾神経線 維が恰も飴でかためた様になつて，その 1 本 1 本を分 離する事ができない. 組織像でこの外套は主として線 維素からなり，少しの細胞浸潤を交えている，その後 アメリカでも同様の論文がでて, 此の様な変化は, ぺ ニシリンの持つ線維素析出作用に因る事が明らかにな り，純度の高いアメリカ製品でも安心できない事を知 つた。同論文でもペニシリンの髄管内注入は強く制 限すべき事を強調し，次の様に結んでいる。

1）ペニシリン剤を髄管内に注人する時は十分稀釈 したものを用いる事.

2）その全量を少くする事.

3）注入回数も最小限に止める事.

4）発病初期に大量を全身的に使用し，出来れば髄 管内注入は之を避ける。

之等の事から，吾々はペ斉の使用は筋注を主とし， 重症の場合にのみ 5,000〜 1 万単位を $1 \sim 2$ 回に分け て髄管内に注入し，重篤症状が去ればこれを中止して その後は筋注のみにしている。

結 び

化膿性脳膜炎の内科的療法は，

1. 腰椎穿刺を反覆し，必要によつては 1 日 2 回以 上行う。

2.リコールの採取量は出来るだけ大量，１回60〜 $70 \mathrm{cc}$ とする（持続的排泄の経験によると，1 日のリコ ールの流出量は300〜600ccに昇る).

3. 之に加えて，ガス注入や薬物療法を行う。 薬物はなるべく全身的使用法を選び，髄管内注入は 
最小限に止めるべきである.

4. 全身的使用の薬剤，エレクトラルゴール，トリ パフラビン, ウロトロピン，ネォアルセミノール，マ 一キュロクローム更とサルファ刻, ペ剂, ストマイ 等.

5. サルファ剂, ペ剂併用の場合, 前者を内服, 後 者を筋注とする. 重症期に限りぺ剂の5000〜 万単位 を $1 \sim 2$ 回に分けて髄管内に注入する. ストマイの使 用もぺ剂と同様に全身的使用を主とし，髄管内注入は 1/20〜1/40g位に止めるのが可い.

批 判

女

\section{I. 実験的研究}

1）大谷信雄 : 脳膜荻に続発せる耳迷路炎の実験的 研究補遗. 北越医会誌 43,2 , 昭3.

2) 大谷信雄 : 耳性化膿性稱膜炎の聴器 病 理に就 て. 日耳鼻 35, 4, 昭 4 .

3）前田謙次郎：化膿性脳膜炎の薬物療法に関する 実験的研究. 日耳鼻 36,10 , 昭 6 .

4）前田謙次郎：腰椎穿刺の価值に関する研究。日 耳鼻 37, 3, 昭6.

5）金野㦑：実験的化膿性脳膜炎における「リコー ル」血液および尿変化について。 日耳鼻 $\mathbf{3 7}, 6$, 昭6.

6）金野㜊：化膿性脳膜炎の診断および治療に関す る研究. (その 1 ) 実験的化膿性脳膜炎における 脳脊䯣夜, 血液, 尿及び眼底の変化について。 日耳鼻 38, 1, 昭7.

（その 2） 化膿性脳膜炎の脊椎管内薬物療法に 関する実験的研究。

第 1 編 薬物の脳膜刺㦸に関する研究.

1. 脳脊髄夜所見による薬物の脳膜刺㦸並び に血夜像におよほす影響について。取 鼻 38, 1, 昭7.

2. 薬物の脳膜刺㦸に関する病理組織学的所 見. “北越医会誌 47,4 , 昭7.

第 2 編 薬物の拡散に関する研究. 日耳鼻 $\mathbf{3 8}$, 1 , 昭7.

第 3 編 薬物の殺菌力に関する研究. 日耳鼻 38, 1, 昭7.

第 4 編 脊椎管内注入による莧物の治療的並び に予防的効果についての組 織学的研 究. 日耳鼻 38,2 , 昭7.
ペ剂やストマイの出現によつて本症の治療にも明る い希望が持てる様になつた。然し，アメリカの様に 600万〜 700万単位と云う樣な大量のぺ剂を使用して も，その治療率は約 $30 \% に$ 過ぎい。この成績は吾々 の外科的療法のみによる成績により寧ろ低いのであ る.

ペ剂使用によつて耳性脳膜炎の70〜80\%が治瘜した と云う人もいるが，今日のところ内科的療法のみで本 症の多数が確実に治ると信ずる者は誰もないであら う. 筆者は外科的療法と之ら薬剤の併用によつて, 治 瘜率をどれだけ向上させ得るかを嘱目している。

献

7）金野㦑：化膿性脳膜炎の脊椎管内薬物療法に関 する実験的研究. 日耳鼻 $\mathbf{3 8 ,} 7$, 昭7.

8）深瀬亮作：化膿性脳膜炎に関する研究. 腰椎弓 切除術による脳脊䯣液の接続的排泄が治瘺機転 に及洣す影響。北越医会誌 49,5 , 昭 9 .

9）深瀬亮作：化膿性脳摸炎の治療に関する研究 その 1 諸種薬剤の静脈内注射による白血球 像, 血清並に脳脊髄液殺菌力の変化に ついて. 北越医会誌 49,4 , 昭 9 .

その 2 血清, ワクチンおよびコクチゲンの脊 髄管内注射療法. 北越医会誌 49,8 , 昭9.

その 3 抗体の脳脊髄管内移行に関する補助的 楽剂に就て. 北越医会誌 49,8 , 昭9.

10）深瀬亮作：ウラニン及び酸性フクシンの脳脊髄 液内移行要約に関する実験的研究. 北越医会誌 49, 8, 昭9.

11）林啓介：化膿性脳膜炎のガス療法に関する実験 的研究.

1. 実験的化膿性脳膜炎に及ほすす各種ガス体蜘蛛膜 下腔注入の治療効果. 北越医会誌 $\mathbf{5 8}, 2$, 昭 18 .

2. 各種ガス体の正常家鬼蜘蛛膜下腔注入に因る一 般症状殊に体温, 血液像並に脳脊䯣液所見. 北 越医会誌 58, 3, 昭 18.

3. 各種ガス体の蜘蛛膜下腔注入が軟䋞膜内被細胞 に及注す影響. 北越医会誌 $\mathbf{5 8 , 4}$, 昭 18.

4. 各種ガス体の脳膜刺㦸に関する一般病理組織学 的研究. 北越医会誌 58,4 , 昭 18 .

12）三林茂雄：化膿性脳膜炎の治潦に関する研究， ズルフオンアミド製剤つ蜘蛛膜下腔注入に関す 万実験的研究. 新潟医会誌 掲載予定. 
13）三林茂雄：化膿性脳膜炎の治療に関する研究. ズルフォアミド製剤の蜘蛛膜下腔注入による各 種臓器の病理組織学的変化. 日本病理学誌 掲 載予定.

14）鹿野秀一：抗生物質（ペニジリンおよびストレ プトマイシン）の髄膜刺㦸，㕹液内移行並に髄 液内における消長に関する研究. 耳鼻臨床 44, 11 , 昭 26.

II. 臨床的研究

1）鳥居恵二：迷路全剔出に因て治瘾したる耳性化 膿性脳膜炎の 2 例. 耳鼻臨床 21, 1, 昭 2 .

2）鳥居恵二：迷路全摘出に因て治瘜したる耳性化 膿性脳膜炎第 3 例報告. 耳鼻臨床 22,1 , 昭 3 .

3）鳥居恵二：耳性化膿性脳膜炎の外科的療法とそ の時期. 北越医会誌 44, 8, 昭4.

4）鳥居恵二，浅野博：内耳摘出，内聴道付近に於 て脳橋槽を開放し治瘜したる耳性化膿性脳膜炎 の一例. 耳鼻臨床 $\mathbf{2 4}, 2$, 昭 5.

5）前田謙次郎：腰椎穿刺の価値に関する研究（前 篇) 臨床的観察。日耳鼻 $\mathbf{3 7 , 2}$, 昭 6.

6）鳥居恵二, 目黒隆 : 脳膜炎治瘺例（脑橋槽並に 脊髄腔ドレナージ)。耳鼻科 4,8 , 昭 6.

7）鳥居恵二：最近わが教室に於ける化膿性䋞膜炎 の治療法 (内耳摘出脳橋槽開放腰椎管開放). 北越医会誌 49,8 , 昭 6 .

8）鳥居恵二 : 耳性化膿性脳膜炎と最近の手術療 法. 臨講 18 , 昭6.

9）前田謙次郎：血液像並に脳脊髄夜所見より見た る化膿性脳膜炎と類症鑑別，グレンッ $\mathbf{5} ， \mathbf{1 1}$ ， 昭6.

10）鳥居恵二：耳性化膿性脳膜炎の治療に就て．耳 鼻臨床 26, 2, 昭6.

11）鳥,居恵二 : 耳性化膿性脳膜炎の治療に就て. 医 界進 316, 昭7.

12）鳥居恵二 : 化膿性脳膜炎の非観血的療法. 耳鼻 臨床 27,4 , 昭8.

13）永井武雄，小泉重政：化膿性脳膜炎を合併せる 静脈賔血栓治癒例。耳鼻科 6,2 , 昭 8 .

14）鳥,居恵二, 斎藤定 : 耳性化膿性脳膜炎の一治験 例. 脳橋槽並に腰椎管開放患者供覧. 北越医会 誌 48, 14, 昭8.

15）深瀬亮作：耳性脳膜炎の早期症状に就て.耳鼻 臨床 29, 2, 昭9.

16）鳥居恵二：化膿性脳膜炎の早期症状並に治療。
診断治療 21, 11, 昭9.

17）鳥居恵二 : 腰椎管開放を行いて治療せる化腄性 脳膜炎. 耳鼻科 8,8 , 昭 10 .

18）平野雄三郎：耳性化膿性脳膜炎の治療に関する 知見. 北越医会誌 $\mathbf{5 0}, 12$, 昭 10.

19）小泉重政，林啓介：丹毒を併発せる耳性化膿性 脳膜炎治験例. 北越医会誌. 50, 12, 昭 10.

20）北村雄次郎：耳性頭蓋内合併症に於ける眼所見 に就いて. 北越医会誌 50,12, 昭 10 .

21）平野雄三郎：耳性化膿性脳膜炎の治療に関する 知見. 日医新報 714, 1727, 昭11.

22）鳥居恵二：耳鼻科領域に於汀る脳内合併症。臨 床内科 2,7 , 昭 11.

23）吉川謹一，小島清：耳性化膿性脳膜炎の一治験 例. 耳鼻科 11, 5, 昭13.

24）鳥居恵二：化膿性脳膜炎の治療法。北越医会誌 53, 12 , 昭 13.

25）金野㦑：耳性化脰性脳膜炎の診断及び治療。臨 床医学 27,1 , 昭 14.

26）木村通明，佐藤謙介：急性化膿性脳膜炎（持続 的脳脊髓夜排泄に依て治瘾せる）の 1 例. 耳鼻 科 12, 8, 昭14.

27）木村通明：化膘性脎膜炎の治験二例. 北越医会 誌 55, 2, 昭 15.

28）宮尾正雄：腰椎管開放に传り治瘾せる耳性化膿 性脳膜炎の興味ある 1 例. 北越医会誌 $\mathbf{5 5}, 2$, 昭15.

29）菊池三通男 : 耳性外旋神経麻痺にホルネル様症 候を伴へる脳膜炎治験例. 医事公論. 1510, 2117, 昭 16.

30）鳥居恵二 : 耳性化膿性脳膜炎の小統計とその治 療法. 日耳鼻 48, 12, 1367. 昭7.

31）鳥居恵二 : 林啓介, 化膿性脳膜炎のガス療法. 日本健康 3330, 796, 昭 18.

32）阿部良七, 広谷常治：耳性化膿性脳膜炎治験例. 耳鼻科 16, 7, 昭 18 .

33）三林茂雄：化膿性脳膜炎の統計的観察. （その 1）一般的観察. 北越医会誌 59, 5, 昭19. （その 2 ）血液並に脳春髄液所見とその予後. 北越医会誌 59, 7, 昭 19 .

34）鳥居恵二：化膿性脳膜炎治療の重点に何をおく べきか. 新潟医会誌 61，4, 昭 22.

35）金野徼，伊藤章：化膿性脳膜炎治療に就いて考 えさせられたこと。日耳鼻 51, 5, 昭22. 
36）中川正平 : 癲痹性発作を来せる耳性脳膜炎。日 耳鼻 51, 5, , 昭23.

37）矢部寛，野多村茂：耳性化膿性脳膜炎の一治験 例. 耳鼻臨床 43, 4, 昭 25 .

38）中川正平，磯野節：亦脳膿瘍並に化膿性脳膜炎 を合併せる耳性静脈䔰血栓例. 耳鼻科 21，4， 昭24.

39）鳥居恵二, 矢部寛, 野々村茂 : 耳性化膿性脳膜 炎の一沿験例. 耳鼻臨床 42, 9 10, 昭24.
40）矢部寛，渡辺俊夫：耳性化膿性脳膜炎の一治験 例. 東京医事新誌 66,11 , 昭 24 .

41）鳥居恵二，矢部寛，渡辺俊夫：耳性化膿性脳膜 炎の一治験例。（腰椎管，内耳道開放ペニシリ ン大量使用) 耳鼻科 22,2 , 昭25.

42) 渡辺俊夫 : 乳児耳性化膿性脳膜炎の一剖検例. 日耳鼻, 53; 3, 昭25.

43）鳥居恵二：化膿性脳膜炎の内科的療法. 耳鼻臨 床 43,3 , 昭 25 . 